Universidade de São Paulo

Instituto de Física

Instituto de Química

Instituto de Biociências

Faculdade de Educação

\title{
O USO DO JOGO AUTÓDROMO AlQUÍMICO COMO MEDIADOR DA APRENDIZAGEM NO ENSINO DE QUÍMICA.
}

ELIANA MORAES DE SANTANA

Orientadora: Prof ${ }^{\mathrm{a}}$. Dra ${ }^{\mathrm{a}}$. Daisy de Brito Rezende

São Paulo

2012 


\section{ELIANA MORAES DE SANTANA}

\section{O Uso do Jogo Autódromo Alquímico como mediador da aprendizagem no Ensino de Química.}

Dissertação de mestrado apresentada ao Instituto de Física, ao Instituto de Química, ao Instituto de Biociências e a Faculdade de Educação da Universidade de São Paulo, para a obtenção do título de Mestre em Ensino de Ciências.

Orientadora: Prof ${ }^{\mathrm{a}}$. Dra ${ }^{\mathrm{a}}$. Daisy de Brito Rezende

São Paulo

2012 


\section{AUTORIZO A REPRODUÇÃO E DIVULGAÇÃO TOTAL OU PARCIAL DESTE}

TRABALHO, POR QUALQUER MEIO CONVENCIONAL OU ELETRÔNICO, PARA FINS DE ESTUDO E PESQUISA, DESDE QUE CITADA A FONTE.

\section{FICHA CATALOGRÁFICA \\ Preparada pelo Serviço de Biblioteca e Informação do Instituto de Física da Universidade de São Paulo}

Santana, Eliana Moraes de

O uso do jogo autódromo alquímico como mediador da aprendizagem no ensino de química. -. São Paulo, 2012

Dissertação (Mestrado) - Universidade de São Paulo. Faculdade de Educação. Instituto de Física, Instituto de Química e Instituto de Biociências

Orientadora: Profa. Drª . Daisy de Brito Rezende

Área de Concentração: Ensino de Ciências

Unitermos: 1.Educação; 2. Ensino; 3. Aprendizagem;

4. Atividades lúdicas; 5. Jogos

USP/IF/SBI-001/2012 


\section{DEDICATÓRLA}

Dedico este trabalfo primeiramente a $\mathscr{D}_{\text {eus. }}$ Tos meus avós que mais que avós foram meus pais. Obrigada por servirem de exemplo na minfia vida.

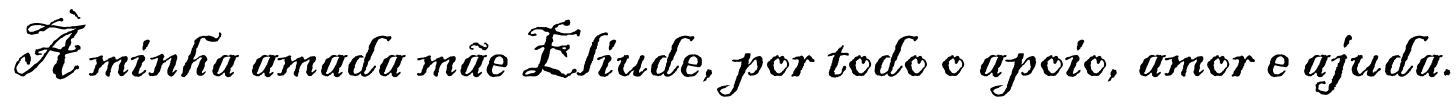

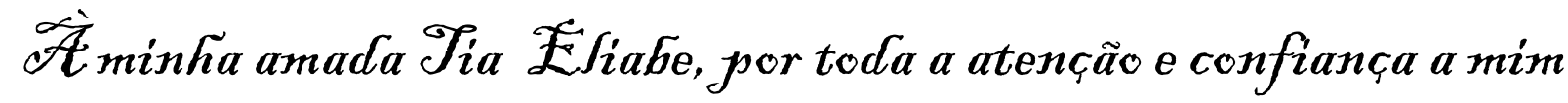
dedicada.

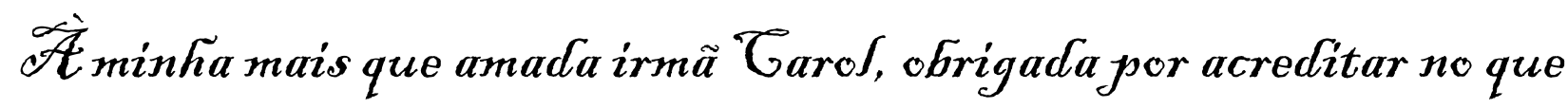
eu faço e me dar força para continuar futando. Tos grandes amores da minha vida, Renato e Lavinnya (in memorian), por transformarem meus sontios em reafidade hoje e sempre. 


\section{AGRADECIMENTOS}

A realização deste trabalho só foi possível graças à colaboração direta e indireta de muitas pessoas. Manifesto a minha gratidão a todos, de forma particular:

A todos os meus familiares, mãe, avós, tias, irmãos, cunhados e sobrinhos, primas e primos e marido que figuraram como importantes na motivação e incentivo para que eu pudesse estar enfrentando esta empreitada;

Aos Professores Edson José Wartha (orientador do meu Trabalho de conclusão de curso da UESC) e Marcelo Pimentel, que perante os momentos cruciais que constituíram a base dessa caminhada me ensinaram o verdadeiro sentido em aprender e ensinar Química;

Aos meus amados alunos, sujeitos protagonistas neste trabalho, sem os quais esta conquista não teria sentido ou mesmo se concretizado;

A minha orientadora, Prof ${ }^{a}$. Dra. Daisy de Brito Rezende, pelo respeito, carinho, paciência e competência com que me orientou na elaboração deste trabalho;

Aos Pais da minha orientadora Wilson Rezende (in memoriam) e Delma, pelo apoio, pelo teto e carinho no momento que mais precisei.

Aos meus amigos da Bahia e da UESC, Christian, Marcos, Márcia (Macinha), Vanessinha, Michelle e Luciana. Aos meus amigos da Escola Pio XII. Cristina, Luizinho, Diana, Wilson, Socorro, Rafaela, Lucianne, Paulo, Edric e Tiago, nem tenho palavras para agradecer o que vocês fizeram por mim.

Aos meus ex-alunos da minha primeira turma no ano de 2002 que se tornaram meus amigos, Camila, Romário, Fernanda, Dawis, Silas, Tálisson, Gabriela e todos os demais que fizeram com que eu me apaixonasse pela minha profissão. Vocês nem tem idéia do quanto foram fundamentais para a realização dos meus projetos!

Aos meus amigos do mestrado, Leonardo, Marcos Vogel, lara, Márcia, Gracielle, Suzéte, Renato, Ricardo, Ana Paula, Renata e Crizélia pelo apoio e incentivo 
demonstrados, pelo carinho e pelas diversas contribuições solicitadas e prontamente atendidas.

Agradeço também aos meus professores, tanto os do Ensino fundamental (Tia Zezé, Tia Rita, Tio Paulo e Tio Wilson), os do ensino médio (Sônia, Denise e Christian) quanto os do ensino superior (Teco, Rosilene, Rosenira, Reinaldo, Alcione, Renê, Fernando, Clemildes e Raildo) agradeço pelos ensinamentos e pelo exemplo de profissionais que são.

Aos meus professores do mestrado (Maria Eunice, Agnaldo Arroio, Carmem Fernandez, Edda Bomtempo e a Daisy Rezende é claro) e de mini-cursos pelos congressos do Brasil afora (Marlon Soares, entre outros) que foram fundamentais na minha formação.

Por fim, agradeço a equipe médica (Dr. Rafael Andrade, Dra Marluce Leão, Drạ. Dóris e $\mathrm{Dr}^{\mathrm{a}}$ Neyde) que cuidaram de mim e sem os quais eu não poderia ter voltado para concluir esse trabalho. 
"Wuma tentativa de resumir as caracteristicas formais do jogo, poderíanos considerá-fo uma atividade livre conscientemente tomada como ñä-séría é exterior à vida habitual, mas ao mesmo tempo capaz de absorver o jogador de maneira intensa e total. Euma atividade desfigada de todo e qualquer interesse material, com a qual näo se pode obter qualquer fucro, praticada dentro de fimites espaciaise temporaís próprios, segundo uma certa ordem e certas regras. Promove a formação de grupos sociais com tendência a rodearem-se de segredo e a subfintiarem sua differença em relação ao resto do mundo por meio de dis farces ou outros meios semelhantes."

(HUIZINGA, 2004, P. 16) 


\section{RESUMO}

SANTANA, Eliana Moraes. O Uso do Jogo Autódromo Alquímico como mediador da aprendizagem no Ensino de Química. São Paulo, 2012. 202p. Dissertação de Mestrado- Instituto de Física, Instituto de Química, Instituto de BiociênciasFaculdade de Educação- Universidade de São Paulo.

O objetivo dessa pesquisa foi analisar um jogo didático intitulado Autódromo Alquímico e como esse tipo de metodologia pode contribuir para o Ensino de Química. As hipóteses de trabalho a priori são que atividades lúdicas e jogos desse tipo podem (i) favorecer a motivação dos alunos e o interesse dos mesmos em aprender (ii) desenvolver nos educandos habilidades cognitivas através das Funções Psicológicas Superiores (FPS) tais como: Emoção, Imaginação, Percepção, Atenção, Memória, Pensamento, Linguagem, Abstração e Generalização, por fim,(iii) possibilitar a significação e o aprofundamento do conhecimento a respeito da Alquimia e da Química.

A pesquisa foi realizada na perspectiva do método de análise qualitativa, sendo desenvolvida nos moldes do estudo de caso. O Referencial Teórico utilizado e em relação à função do jogo é baseado em Vygotsky e seus alunos, Leontiev e Elkonin principalmente. A atividade lúdica trabalhada foi o Jogo Autódromo Alquímico e todas as suas etapas de aplicação inseridas no contexto da Educação em Química. Os colaboradores do trabalho foram 263 estudantes de nove turmas do $9^{\circ}$ ano do Ensino Fundamental de uma escola particular da cidade de Itabuna no estado da Bahia. A obtenção dos dados foi realizada através de análises diagnósticas (iniciais, continuadas e finais) com perguntas abertas, além de filmagens digitais e entrevistas com os educandos sendo, posteriormente, tratados com a utilização de ferramentas da análise de conteúdo. Os resultados encontrados corroboraram as três hipóteses (i) (ii) e (iii). Os dados encontrados demonstraram existir uma relação direta entre a aplicação da 
atividade lúdica e uma maior ressignificação e aprofundamento do conhecimento em Química.

Conclui-se que o Jogo foi benéfico para o processo de ensino e aprendizagem em Ciências, pois houve aprendizagem e ressignificação do conhecimento da Alquimia e da Química. Também foi perceptível o desenvolvimento de várias habilidades apontadas como importantes para a formação de um cidadão crítico e reflexivo.

Palavras-Chave: Atividades Lúdicas,

Jogos,

Ensino de Química,

Autódromo Alquímico,

Mediação. 


\section{Abstract}

SANTANA, Eliana Moraes. The Use of game Alchemical Speedway as a mediator of learning in the Chemistry Teaching. São Paulo, 2012. 202p. Master's Thesis- Institute of Physics, Institute of Chemistry, Institute of Biosciences -Scholl of EducationUniversity of São Paulo.

The objective of this research was to analyze a didactic game titled Alchemical Speedway and how such a methodology can help to teach chemistry. Working hypotheses are that play activities and games of that type may (i) foster students' motivation and interest in learning the same (ii) to develop in students the higher psychological functions (FPS) such as: Emotion, Imagination, Perception, Attention, Memory, Thought, Language, Abstraction and Generalization, finally, (iii) enable the significance and deepen the knowledge of alchemy and chemistry.

The survey was conducted in view of the method of qualitative analysis, being developed as a case study. The theoretical basis and in relation to the function of the game is based on Vygotsky and his students, Leontiev and Elkonin mainly. Leisure activity was crafted game Alchemical Speedway and all stages of application placed in the context of Education in Chemistry. Employees of the study were 204 students from nine classes in 9th grade of elementary school to a private school in the city of Itabuna in the state of Bahia. Data collection was performed through diagnostic tests (initial, continuing and final) with open questions, in addition to digital footage and interviews with the students and subsequently treated with the use of tools of content analysis. The results corroborate the three hypotheses (i) (ii) and (iii). The data showed a direct relationship exists between the application of leisure activity and a major reframing and deepening of knowledge in chemistry.

We conclude that the game was beneficial to the process of teaching and learning in science, because there was learning the knowledge of Alchemy and Chemistry. 
Also noticeable was the development of various skills identified as important for the formation of a critical and reflective citizen.

KEYWORDS: RECREATIONAL ACTIVIDIES, GAMES, Chemistry Teaching, Alchemical Speedway, MEDiATOR. 


\section{LISTA DE FiguRAS}

Figura 2.1 Filme Harry Potter e a Pedra Filosofal............................................... 40

Figura 2.2 Coleção dos Jogos de Play Station de Harry Potter ............................... 41

Figura 2.3 Instrumentos Lúdicos adaptados dos filmes Harry Potter ........................ 41

Figura 2.4 Imagens do mais novo parque da Warner Bros:

O Reino encantado de Harry Potter

Figura 2.5 Imagem do personagem de um alquimista no RPG. ............................43

Figura 2.6 Imagem do personagem que representa um mago no jogo de RPG.......44

Figura 2.7 Imagens dos filmes e desenhos animados do Fullmetal Alchemist...........46

Figura 2.8 Imagens dos Jogos de Vídeo Games (PlayStation 2) ...........................46

Figura 2.9 Imagens dos Mangás e de Jogos do Fullmetal Alchemist ......................47

Figura 2.10 Imagens do livro e minissérie o Pequeno Alquimista .............................48

Figura 2.11 Box retirado da revista Recreio tratando da temática da pedra filosofal...49

Figura 4.1 Fluxograma descrevendo aspectos positivos e negativos da utilização das atividades lúdicas no ensino ......................................................... 57

Figura 6.1 Fluxograma com categorias e subcategorias dos jogos..........................86

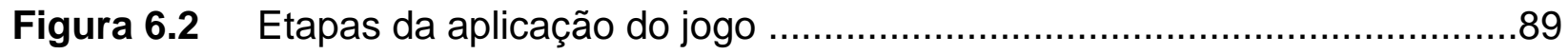

Figura 6.3 Tabuleiro do autódromo alquímico ……............................................92

Figura 6.4 Montagem e aplicação-piloto do Autódromo Alquímico gigante (turma piloto A) .96

Figura 6.5 Montagem e aplicação-piloto do Autódromo Alquímico gigante (turmas piloto $\mathrm{B}$ e $\mathrm{C}$ ) 
Figura 6.6 Aplicação do Autódromo Alquímico em equipes (Turmas D, E, F, G)....98

Figura 6.7 Aplicação do Autódromo Alquímico em equipes (Turmas $\mathrm{H}$ e I)...............99

Figura 6.8 Tipos de Avaliações Diagnósticas ....................................................100

Figura 6.9 Processo de Coleta de Análise de Dados - Fase Inicial) .....................104

Figura 6.10 Processo de Coleta de Análise de Dados - Fase Intermediária.............104

Figura 6.11 Processo de Coleta de Análise de Dados ..........................................105

Figura 7.1 Gráfico Comparativo das nacionalidades e anos de publicação dos jogos

Figura 7.2 Relação das Funções Psicológicas (Superiores e Elementares) com os jogos publicados entre 1929-1999

Figura 7.3 Relação das Funções Psicológicas (Superiores e Elementares) com os jogos publicados entre $2000-2009$ 118

Figura 7.4 Gráficos de 9 turmas com os resultados da Palavra Alquimia. 122

Figura 7.5 Gráficos de 9 turmas com os resultados do ponto em comum entre Alquimia e Química. 153

Figura: 7.6 Gráficos de 9 turmas com os resultados das diferenças entre Alquimia e Química. 


\section{LISTA DE QUADROS}

Quadro 2.1 Conteúdos sobre o Panorama histórico da química que aparecem nos livros didáticos (Peruzzo e Canto, 2006)..............................................32

Quadro 2.2 Conteúdos sobre Alquimia que aparecem nos livros didáticos de Química

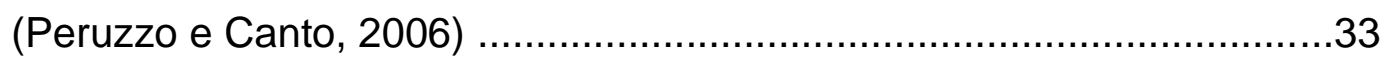

Quadro 2.3 Conteúdos sobre Alquimia e Química que aparecem nos livros didáticos de (Peruzzo e Canto, 2006)

Quadro 2.4 Conteúdos sobre Alquimia que aparecem nos livros didáticos de Química (Reis, 2007)

Quadro 2.5 Conteúdos sobre Alquimia que aparecem nos livros didáticos de Química (Enciclopédia do estudante: Química Pura e Aplicada, 2008)

Quadro 2.6 Trecho do filme Harry Potter e a Pedra Filosofal onde aparece a temática a ser trabalhada

Quadro 2.7 Descrição do personagem do RPG: o Alquimista. .44

Quadro 2.8 Descrição dos personagens de RPG :Magos. .44

Quadro 2.9 Descrição dos personagens de RPG: Feiticeiros 45

Quadro 6.1 Domínios possíveis da aplicação da análise de conteúdo 107

Quadro 7.1 Alquimia e Transformações. 120

Quadro 7.2 Alquimia e Pré-Química 120

Quadro 7.3 Alquimia e Magia 121

Quadro 7.4 Alquimia e Motivações 124

Quadro 7.5 Transformação e Alquimistas 125

Quadro 7.6 Pré- Química e Alquimistas .125

Quadro 7.7 Magia e Alquimistas. 126

Quadro 7.8 Experimentação e Alquimistas. 126 


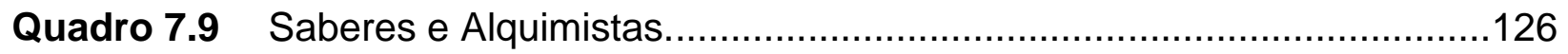

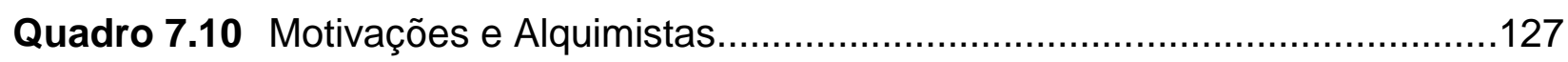

Quadro 7.11 Transformação e a Pedra Filosofal .................................................127

Quadro 7.12 Magia e a Pedra Filosofal ........................................................128

Quadro 7.13 Motivações e a Pedra Filosofal ..........................................................129

Quadro 7.14 Conceitos e a Pedra Filosofal ........................................................129

Quadro 7.15 Química e Transformação ............................................................131

Quadro 7.16 Pré- Química e Química …………............................................131

Quadro 7.17 Conceitos e Química .................................................................132

Quadro 7.18 Transcrição da fala de alguns alunos sobre o filme e jogos.................134

Quadro 7.19 Transcriação de parte da filmagem do grupo 2 turma $\mathrm{H}$..................... 136

Quadro 7.20 Transcriação de parte da filmagem do grupo 3 turma I. .....................139

Quadro 7.21 Transcriação de parte da filmagem do grupo 1 turma $H$..................... 141

Quadro 7.22 Transcriação de parte da filmagem do grupo 3 turma H................... 142

Quadro 7.23 Transcriação de parte da filmagem do grupo 5 turma I...................... 145

Quadro 7.24 Transcriação de parte da filmagem do grupo 6 turma H.................... 148

Quadro 7.25 Pontos em comum entre Alquimia e Química- Transformação.......... 150

Quadro 7.26 Pontos em comum entre Alquimia e Química- Experimentação ....... 150

Quadro 7.27 Pontos em comum entre Alquimia e Química- Motivações ............... 152

Quadro 7.28 Pontos em comum entre Alquimia e Química- Conceitos.................. 152

Quadro 7.29 Diferenças entre Alquimia e Química- Transformação ....................... 154

Quadro 7.30 Diferenças entre Alquimia e Química- Experimentação ..................... 155

Quadro 7.31 Diferenças entre Alquimia e Química- Conceitos ............................. 155 


\section{LISTA DE TABELAS}

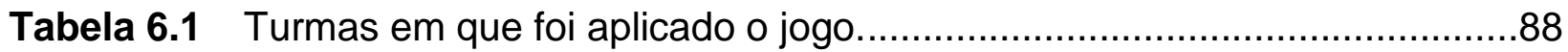

Tabela 6.2 Etapas da Metodologia da Atividade Lúdica ...........................................90

Tabela 6.3 Categorias construídas para as análises diagnósticas ..........................106

Tabela 6.4 Definição das Funções Psicológicas Superiores ...................................106

Tabela 7.1 Categorias 1 e 2 ( ano de publicação e nacionalidade) ….......................112

Tabela 7.2 Publicações Nacionais e Internacionais nos últimos 10 anos ................114

Tabela 7.3 Publicações Nacionais em congressos nos últimos 10 anos ................115

Tabela 7.4 Categoria 3 ( nível de cognição) …….................................................. 116

Tabela 7.5 Resultados em porcentagem (\%) da Palavra 1: Alquimia .....................120

Tabela 7.6 Resultados em porcentagem (\%) da Palavra 2: Alquimistas .................124

Tabela 7.7 Resultados em porcentagem (\%) da Palavra 3 Pedra Filosofal ........... 128

Tabela 7.8 Resultados em porcentagem (\%) da Palavra 4 Química ...................... 130

Tabela 7.9 Ponto em comum entre Alquimia e Química ......................................149

Tabela 7.10 Diferença entre Alquimia e Química ............................................... 153 


\section{LiSTA DE ABREViaturas e SIGLAS}

EDUQUI- Ba: Encontro de Educação em Química da Bahia

ENEQ: Encontro Nacional de Ensino de Química

ENPEC: Encontro Nacional de Pesquisa e Ensino de Ciências

FPE: Funções Psicológicas Elementares

FPS: Funções Psicológicas Superiores

PCNEM: Parâmetros Curriculares Nacionais do Ensino Médio

PCN+: Parâmetros Curriculares Nacionais +

RASBQ: Reunião Anual da Sociedade Brasileira de Química

UESC: Universidade Estadual de Santa Cruz 


\section{SUMÁRIO}

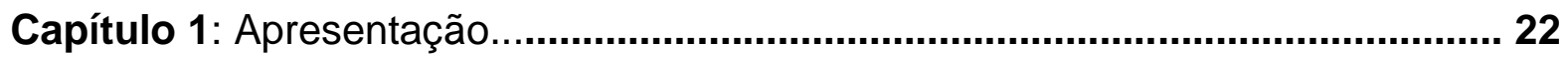

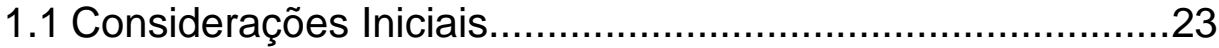

1.2 Estrutura da Dissertação..................................................25

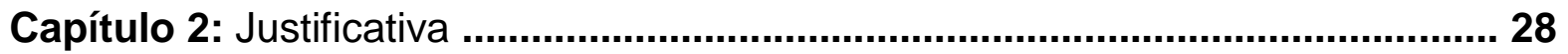

2.1. Definição do Tema Central ................................................30

2.1.1. Livros e Filmes ..................................................40

2.1.2. RPG ( Role Playing Games) ................................43

2.1.3. Desenhos animados, quadrinhos e games .............45

2.1.4. Minisséries e Seriados ........................................ 47

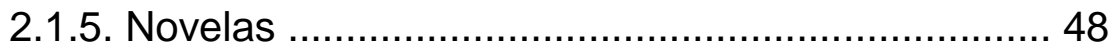

2.1.6. Documentários ................................................. 48

2.1.7. Revistas ....................................................... 49

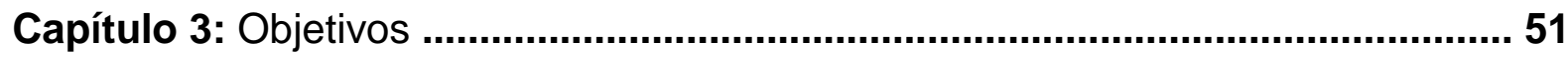

Capítulo 4: O Universo Lúdico e os Jogos ............................................................ 54

4.1. Atividades Lúdicas no contexto escolar .............................55

4.2. A Influência das atividades lúdicas na aprendizagem .......... 58

4.3. O Uso de atividades lúdicas nas ciências da natureza ...... 60

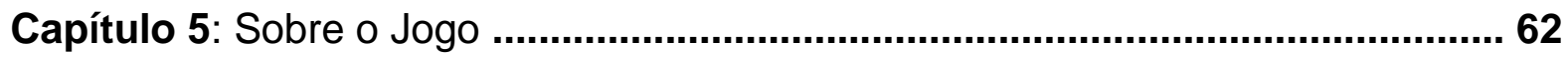

5.1. A Teoria histórico-cultural e os jogos ....................................63

5.2. Os jogos e o desenvolvimento da criança e adolescentes ....66

5.3. A brincadeira e o jogo na pespectiva Histórico- Cultural ...... 71 
5.4. A Mediação e o Desenvolvimento das Funções Psicológicas

Superiores.

5.5. Desenvolvimento das FPS através da mediação realizada pelo jogo.

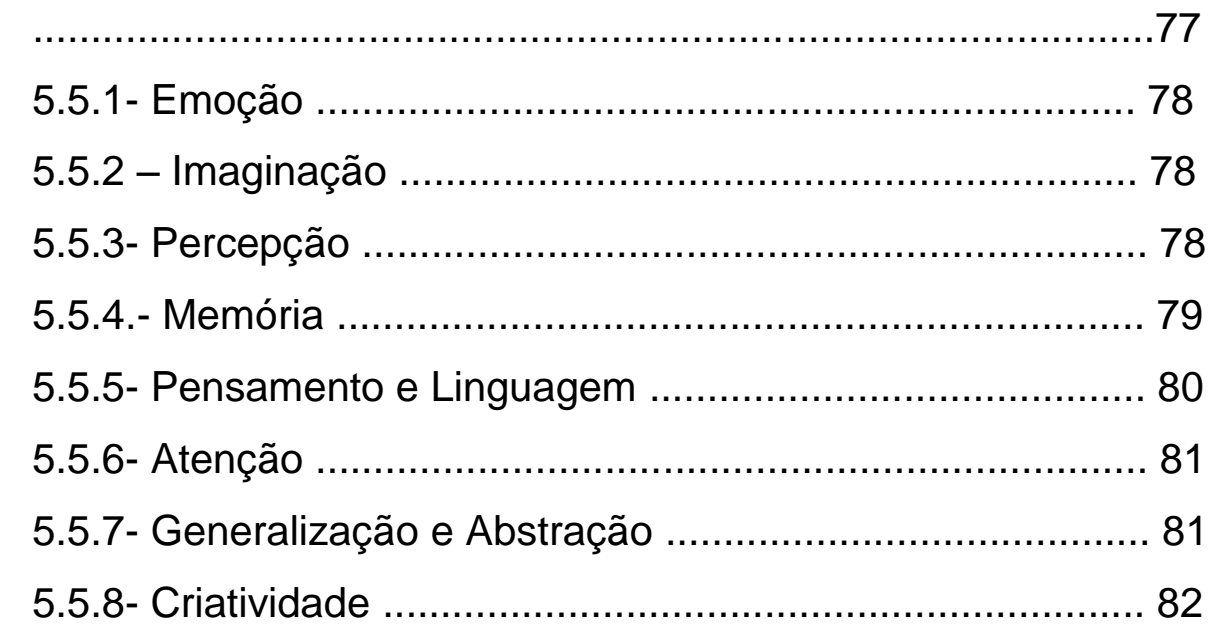

Capítulo 6: Metodologia

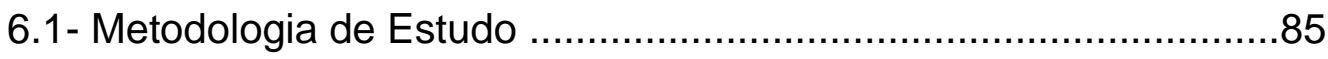

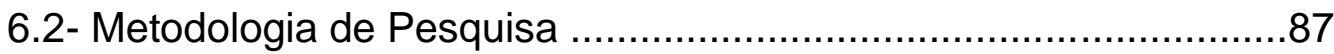

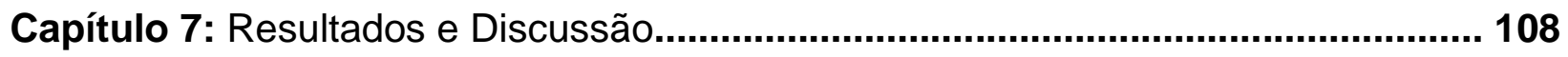

7.1 Análise dos Resultados obtidos na revisão bibliográfica realizada na metodologia de estudo ...........................................................109

7.2 Análises Diagnósticas ( Finais, Continuadas e Finais) …............119

7.2.1-Análise Diagnóstica Inicial ..........................................120

7.2.2- Análise Diagnóstica Continuada .................................. 133

7.2.2.1- Emoção ………........................................... 133

7.2.2.2- Percepção …............................................. 137

7.2.2.3- Atenção ....................................................... 139

7.2.2.4- Memória …................................................. 141

7.2.2.5- Generalização e Abstração ............................143

7.2.2.6- Criatividade .............................................. 145 
Capítulo 8: Considerações Finais

Capítulo 9: Referências Bibliográficas... 161

\section{Anexos}

Anexo A: Análise Diagnóstica Inicial

Anexo B: Análise Diagnóstica Continuada- Filme Harry Potter

Anexo C: Análise Diagnóstica Continuada- Estudo Dirigido

Anexo D: Análise Diagnóstica Continuada- Elaboração das Perguntas usadas no Tabuleiro.

Anexo E: Análise Diagnóstica Continuada:

Anexo F: Análise Diagnóstica Final'- Questionário aplicado aos alunos

Anexo G: Análise Diagnóstica Final - Pós- teste

Anexo H: Análise Diagnóstica Final- Entrevista 
Capítulo 1: APRESENTAÇÃO 
A primeira parte desse capítulo descreve as considerações iniciais que tornaram possível a realização desse trabalho e a segunda parte retrata a estrutura dessa Dissertação que foi dividida em 9 capítulos.

\section{1- CONSIDERAÇÕES INICIAIS}

A idéia da realização deste trabalho surgiu através de uma superação pessoal, quando ainda estudava no ensino fundamental. A única matéria que tive dificuldades foi a Química. Não gostava da disciplina, achava que só servia para decorar fórmulas e fazer contas, além de não conseguir visualizar como aquela tabela periódica poderia fazer parte da minha vida prática. Isso devido à maneira como o professor ministrava as aulas. Foi inevitável criar uma antipatia pela química, e conseqüentemente fiz recuperação dessa matéria considerada naquele momento maçante. Com o passar do tempo, comecei a estudar os assuntos, a priori para passar de ano, e acabei gostando dessa ciência. Isso ocorreu porque de tanto estudar sozinha, comecei a pesquisar minhas dúvidas e minhas curiosidades, tanto em livros como na internet. Para superar as dificuldades com a disciplina comecei a pesquisar e perceber como era interessante e lógica aquela ciência. A conseqüência foi que acabei me apaixonando pela Química e com o apoio dos meus professores do Ensino Médio adquiri uma facilidade no aprendizado da matéria e resolvi prestar o vestibular para Licenciatura em Química.

Fui aprovada, comecei a cursar a universidade (Universidade Estadual de Santa Cruz - UESC, localizada na cidade de Ilhéus no estado da Bahia). Ao mesmo tempo fui convidada pela diretora da Escola Pio XII, em Itabuna- Ba, Eliabe Izabel Lima de Moraes, a assumir a disciplina Química da turma da 8 $^{\underline{a}}$ série da mesma escola onde eu havia estudado o Ensino Fundamental. A turma possuía 33 alunos e esse contato com a sala de aula e alunos foi fundamental para a certeza da minha escolha profissional, pois a partir desse momento eu tive convicção que queria ser professora e de Química, pois me identifiquei muito com a turma e conseqüentemente com a profissão. 
Comecei a participar de vários eventos acadêmicos voltados para o ensino, pois a profissão que escolhi exige essa constante necessidade de atualizações e formação continuada. Os eventos eram de níveis nacional, estadual, regional e mais recentemente também de âmbito internacional. Neles comecei a observar as inovações e metodologias diferenciadas para melhorar e tornar mais agradável o ensino de Química, isso porque eu não queria reproduzir em sala de aula o que me traumatizou no passado.

Ao participar desses eventos, me identifiquei com uma temática: materiais didáticos e atividades lúdicas. Logo comecei a ler, pesquisar e utilizar esse universo em minha sala de aula.

Esse envolvimento com atividades lúdicas, especificamente surgiu após a participação em um dos mini-cursos do EDUQUI (Encontro de Educação em Química da Bahia), cujo tema foi Jogos e Atividades lúdicas aplicadas ao Ensino de Química, realizado no ano de 2003, na Universidade Estadual de Santa Cruz (UESC), ministrado pelo Professor Márlon Herbert Flora Barbosa Soares. A partir daí comecei a refletir sobre novas maneiras de trabalhar o conteúdo de forma lúdica e diferenciada.

.Esse tipo de atividade quando bem elaborada e bem aplicada com objetivos claros e definidos afasta-se do modelo tradicional de ensino, fugindo dos papéis básicos dos professores e alunos, distanciando-se da realidade até então trabalhada onde o professor seria o centro do processo de ensinoaprendizagem, passando a ser mediador entre o conhecimento que o aluno já possui e novas experiências que o aluno necessita aprender. No modelo tradicional o aluno é sujeito passivo, reprodutor e repetidor do processo de aprendizagem e através das atividades lúdicas ele se torna sujeito ativo, construtor de seu conhecimento.

Desde cedo percebi a importância do universo lúdico no processo de ensino - aprendizagem, sendo uma alternativa prazerosa para a melhoria do Ensino de Química. Alguns colegas e professores começaram a observar a maneira lúdica e interessante como eu desenvolvia os temas e passaram também a fazer uma prática dinâmica. Fui orientada a usar essa nova prática como tema de meu trabalho de conclusão de curso por dois professores recém-chegados à UESC :Marcelo Pimentel e Edson Wartha. 
Optei pela elaboração de uma monografia, com o tema " $A$ Influência de Jogos e Atividades Lúdicas no ensino de Química baseados na teoria motivacional de Maslow." (Santana e Wartha, 2006) Apresentei-a, fui aprovada e me formei no ano de 2006.

Os mesmos professores me orientaram a continuar a pesquisa e me influenciaram dando apoio para eu tentar o processo seletivo do curso de PósGraduação Interunidades, modalidade Química aqui da Universidade de São Paulo. Obtive êxito na minha pretensão no ano de 2007. Vim do interior da Bahia, largando família, empregos, minha casa, amigos, e passei a morar em São Paulo.

Dando continuidade à minha pesquisa com atividades lúdicas no Ensino de Química, resolvi aplicar e realizar um estudo de uma atividade criada e adaptada por mim aplicando em nove turmas de 90 anos do Ensino Fundamental. Porém o objeto de estudo desta dissertação em especial é centrado em seis turmas apenas, pois foram aplicadas as mesmas metodologias que são o foco dessa dissertação. As outras três serviram como oficina e aplicação piloto.

Por conseguinte, este trabalho focaliza a nossa experiência na elaboração, construção, aplicação e avaliação de jogos e atividades lúdicas no Ensino de Química, com alunos do 9ª ano do Ensino Fundamental da Escola Pio XII no município de Itabuna no estado da Bahia. Pretendemos apresentar e discutir a importância no processo de ensino e aprendizagem em Química, de jogos e atividades lúdicas,para afirmar a relação íntima entre essas metodologias e as emoções existentes em cada aluno, pois quando os mesmos estão envolvidos emocionalmente no processo de ensino e aprendizagem a mesma é facilitada.

\section{2- Estrutura da Dissertação}

O primeiro capítulo relata uma breve apresentação dos motivos que levaram ao desenvolvimento dessa temática, trabalhada desde a época da graduação da autora deste estudo. O Capítulo 2 aborda a justificativa, ou seja, o motivo que levou à escolha do tema a ser trabalhado, retratando de forma detalhada e 
específica a escolha do tema. A justificativa apresenta também uma breve explanação sobre Alquimia e Química e as formas distintas como podem ser trabalhadas as concepções de transformações dos materiais. Este capítulo é finalizado através da apresentação de objetos (filmes, livros, jogos, desenhos, entre outros) presentes nos universos culturais dos alunos, influenciando assim nas concepções e erros conceituais e epistemológicos identificados neste estudo.

O Capítulo 3 irá detalhar os objetivos da pesquisa e as hipóteses que levaram à escolha da temática metodológica.

O Capítulo 4, denominado o universo lúdico e os jogos, delineia o uso de jogos e atividades lúdicas segundo os mais diversos autores em perspectivas distintas, em uma abordagem cronológica, desde Huinzinga (1996) até os pesquisadores atuais. São ressaltadas, também, algumas abordagens específicas que se referem ao uso dessa metodologia no ensino de ciências, bem como sua influência na aprendizagem.

No capítulo 5, estão apresentadas, de forma sintética, as teorias dos psicólogos soviéticos que seguem as concepções de Vygotsky (2007), que subsidiaram a análise dos resultados do presente trabalho. Faz-se uma análise comparativa das teorias de Elkonin (1998), Luria (1991) e Leontiev (1988), entre outros teóricos. Esses autores se preocupavam com os jogos e suas relações com crianças e adolescentes, bem como com o desenvolvimento das Funções Psicológicas Superiores (FPS) através da mediação aprimorada pela interação social presente no processo do jogo.

No capítulo 6 é descrita a metodologia, que é dividida em duas partes, a metodologia de pesquisa e a metodologia de ensino. Na primeira foi realizado um estudo bibliográfico detalhado sobre o uso de jogos e atividades lúdicas no ensino de ciências (Química) nos últimos 80 anos (1929-2009), pois no ano de 1929 foi publicada a primeira atividade lúdica que envolvia temas voltados ao Ensino de Química. Os jogos arrolados nesta pesquisa bibliográfica foram categorizados considerando-se três aspectos: ano de publicação (antes de 1999 e após 1999), localidade (nacionais ou internacionais), nível de cognição (básicas e elevadas). Nessa categoria, os jogos foram classificados segundo o envolvimento de níveis cognitivos básicos ou elevados, isto é, aqueles que 
desenvolvem Funções Psicológicas Elementares ou Funções Psicológicas Superiores (FPS) (Vygotsky, 2005; 2007).

$\mathrm{Na}$ segunda parte da metodologia é explicado e definido o processo de desenvolvimento, elaboração, aplicação e avaliação do jogo e também o instrumento de coleta de dados e sua análise, em que se optou pela análise de conteúdo (Bardin, 2000). Foram propostas categorizações nas análises diagnósticas inicial e final, que foram de fundamental importância para a obtenção dos resultados e, posteriormente, a discussão dos mesmos.

Os resultados e discussão são descritos no capítulo 7 , em que os resultados obtidos de acordo com as categorizações que emergem da análise de conteúdo (Bardin, 2000) são apresentados, discutidos e avaliados. Foram realizadas as transcriações das filmagens da análise diagnóstica continuada e das entrevistas, sendo possível observar o desenvolvimento das FPS.

O Capítulo 8 apresenta as considerações finais sobre o uso do lúdico no contexto escolar, voltado para o Ensino de Química. No capítulo 9 estão as referências bibliográficas utilizadas. Os anexos estarão apresentados após 0 capítulo 9. 
Segundo os PCNs (Brasil, 1999), o ensino de Ciências Naturais deverá se organizar de forma que os alunos desenvolvam diversas habilidades, entre as quais, a de valorizar o trabalho em grupo, sendo capazes da ação crítica e cooperativa para a construção coletiva do conhecimento, influenciando na construção da autonomia de pensamento e ação, capacitando o aluno a exercer seu papel de cidadão na sociedade.

Nesse âmbito, trabalhar o lúdico permite ampliar a gama de possibilidades pedagógicas utilizadas para o ensino de um determinado saber, neste caso relacionadas ao ensino de Ciências Naturais (Química), de maneira significativa, não possuindo apenas um objetivo específico, lógico e pré-determinado, mas buscando, na efetivação das atividades, a satisfação das expectativas e o sucesso na realização das mesmas (Souza e Alves, 2005).

Nesse contexto, o lúdico, de acordo com os estudos de Menezes e Santos (2006), irá influenciar muito no desenvolvimento das crianças, em todas as faixas etárias, e também em adolescentes e jovens, pois é através do jogo que ela aprende a agir, tem a curiosidade estimulada, adquire iniciativa e autoconfiança, além de proporcionar o desenvolvimento da linguagem, do pensamento e da concentração. O lúdico também se origina na capacidade simbólica, visando à construção do conhecimento e sua socialização. Possibilitará a criação de um ambiente gratificante e atraente, servindo como estímulo para o desenvolvimento integral das pessoas envolvidas no processo, nesse caso, envolvendo crianças, adolescentes e jovens.

O desenvolvimento do jogo Autódromo Alquímico (Santana, 2006; Santana e Wartha 2006; Santana e Rezende, 2007a; Moraes e Rezende, 2009) indica a viabilidade de propostas de uso de jogos no ensino de Ciências (Química). Ao se desenvolver esse tipo de atividade, deve-se planejar detalhadamente o processo, seguindo algumas etapas básicas a que o professor deve proceder para sua elaboração.

A atividade lúdica proposta "Autódromo alquímico" atua no sentido de transformar a visão de jogo e de ensino, mostrando que é possível trabalhar com os jogos em sala de aula, fazendo com que ocorram motivação e inovação do processo de ensino e aprendizagem voltado para as ciências naturais (Química), formando um novo instrumento metodológico de informação, observação e correlação dos conhecimentos adquiridos em sala de aula com o cotidiano do aluno. 


\section{1- Definição do Tema Central}

O principal motivo para a escolha do tema Alquimia como introdução ao estudo da Química deveu-se à pesquisadora ter constatado, ao longo de sua prática como professora das últimas séries do Ensino Fundamental II, que filmes, jogos (RPGs, Vídeos Games), desenhos e livros que remetem a essa temática estão amplamente presentes no universo cultural de alunos dessa faixa etária (seção 2.1.2.1). Entretanto, em geral esses produtos culturais apresentam vários equívocos conceituais e epistemológicos (Quadros 2.3 a 2.6) que, inclusive, se reproduzem em diversos livros didáticos (os quais costumam apresentar a Alquimia como precursora da Química moderna (vide Quadros 2.1 a 2.5). Apesar disso, supõe-se que o interesse dos alunos por um assunto possa levar à facilitação de sua aprendizagem (Cunha, 2008).

A hipótese de que os alunos possuíssem conceitos equivocados e simplistas sobre Alquimia foi corroborada pela análise das respostas de um pré-teste (Anexo I). Assim sendo, decidiu-se abordar a temática da Alquimia e das transformações dos materiais já ao iniciar o curso de Química no $9^{\circ}$ ano do Ensino Fundamental, com o objetivo de estabelecer as diferenças entre os pensamentos alquímicos e químicos (Goldfarb, 2001). Essa compreensão das diferentes visões sobre a Natureza e suas transformações pode contribuir para que estes alunos percebam mais claramente que há diversas abordagens possíveis para a explicação dos fenômenos naturais e que essa articulação é socialmente mediada e se estabelece em um dado contexto histórico-cultural. Essa percepção poderia motivá-los para o estudo dos conteúdos a serem desenvolvidos subseqüentemente, ao longo do período letivo.

Nos quadros 2.1 a 2.5 aparecem trechos de três livros didáticos selecionados devido a maior utilização dos mesmos por professores que trabalham com alunos nessa fase introdutória do ensino de química ( $9^{\circ}$ ano do Ensino Fundamental). Observou-se seus respectivos fragmentos de texto e constatamos que os mesmos apresentam vários equívocos conceituais (relativo a concepções, ideias e definições) e epistemológicos (relativo a teorias ou concepções do conhecimento). 
Nos livros didáticos, é muito comum que a Alquimia apareça como sendo uma pré-química, ou uma precursora da química, como é mostrado nos Quadros 2.1 a 2.5. Mas especificamente os Quadros 2.1, 2.2 e 2.3 apresentam trechos do livro 1 (Peruzzo e Canto, 2006) e os equívocos apresentados neste livro são conceituais e aparecem basicamente em seus subtítulos denominados de :" Alquimia a precursora da Química" e "Da Alquimia surge a Química". Entretanto, ao contrário dessa abordagem, que os subtítulos do livro 1 sugerem, a Alquimia constitui um corpo de conhecimentos que não se caracteriza como uma Química antiga ou arcaica.

De acordo com os estudos de Caldeira (2007), o primeiro momento a ser abordada essa dicotomia aconteceu a partir do século XVII e envolveu de um lado a alquimia com seus conhecimentos milenares de vários povos e culturas e do outro a química, representando um novo paradigma e uma nova concepção de estudo da matéria e suas características. Este momento representou uma passagem da alquimia para a química e ocorreu como reflexo das novas idéias surgidas a partir de intensas transformações econômicas, sociais, religiosas e científicas que aconteceram na Europa a partir do século XV.

Ainda segundo esse autor a química não surgiu como um algoz da alquimia, mas como uma necessidade para ocupar uma lacuna que certamente apareceria, na chamada "ciência moderna", com a saída da alquimia. A alquimia realmente precisaria ser substituída por uma nova ciência, caso contrário ela seria uma peça totalmente desencaixada e isolada da ciência moderna, resultando lentamente no seu descrédito e na sua marginalização dos saberes humanos. Seria vista como uma cultura inferior e seus trabalhos ou pesquisas não mereceriam nenhuma consideração ou valor perante a comunidade científica. (Caldeira, 2007)

Em síntese, o desaparecimento da Alquimia foi um acontecimento inevitável diante da transformação da visão de mundo que the dava suporte e sentido. (Goldfarb, 2001)

Poucos são os livros que falam detalhadamente sobre essa temática, Goldfarb (2001), por exemplo, em seus estudos discute a diferença entre Alquimia e Química em uma rica e detalhada abordagem, em que sustenta que o desaparecimento da Alquimia ocorre em um momento histórico de ruptura entre visões de mundo opostas, não se caracterizando uma evolução de visões de mundo semelhantes, como geralmente aparece nos livros didáticos comuns. 


\section{B Breve panorama histórico}

Entre as Ciências Naturais, pode-se dizer que a Química é uma das mais recentes. Astro nomia, Física e Matemática têm uma história que remonta a muitos séculos antes de Cristo.

Não há uma data específica que possamos colocar como "início" da Química. Podemo: dizer, entretanto, que ela só se firmou como Ciência no transcorrer dos séculos XVII e XVIII Vamos, a seguir, dar uma idéia sobre isso.

\subsection{A Antigüidade}

Cerca de 1500 a.C., os egípcios já utilizavam procedimentos em que estavam envolvida: transformações químicas. Entre elas podemos citar a fabricação de objetos cerâmicos por meic do cozimento da argila, a extração de corantes de certos animais e vegetais, a obtenção de vinagre e bebidas alcoólicas não-destiladas (vinho, cerveja) e a produção de vidro e de algun metais. Destaca-se também a arte da conservação das múmias, na qual os egípcios atingiran alto grau de perfeição.

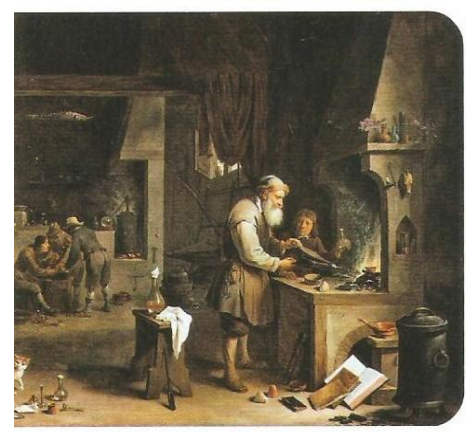

Concepção artística de um laboratório alquímico da Idade Média.

Por volta de 478 a.C., o filósofo grego Leucipo, que vivia na costa norte do Mar Egeu, apresentou a primeira teoria atômica de que se tem notícia, e seu discípulo Demócrito a aperfeiçoou e propagou. A idéia envolvida era a seguinte: considere, por exemplo, a areia de uma praia. Vista de longe ela parece contínua, porém, observada de perto, notamos que é formada por pequenos grãos. Não seriam todas as coisas no universo formadas por "grãozinhos" tão pequenos que não podemos enxergar e, dessa forma, temos a impressão de que elas são contínuas? A esses "grãozinhos" foi dado o nome de átomos (do grego a, que significa "não", e tomos, que quer dizer "divisível").

Contudo, entre os gregos, acabaram predominando as idéias de outro filósofo, Aristóteles (384-322 a.C.). Segundo ele, tudo é constituído de quatro "elementos" básicos: fogo, terra, ar e água. Essa maneira de pensar influenciou muito a evolução da Ciência ocidental, que conseguiu desvencilharse totalmente dessas idéias somente no século XVI, a partir do qual a Química teve considerável impulso.

Quadro 2.1- Conteúdos sobre o Panorama histórico da química que aparecem nos livros didáticos (Peruzzo e Canto, 2006).

Assim, a Alquimia e o homem alquímico relacionavam-se com a Natureza apoiados em uma visão cosmológica, mágico-vitalista e qualitativa do mundo, enquanto a Química e o homem químico se dirigem à Natureza com um olhar filosófico, mecanicista e quantitativo, propondo uma nova maneira de conceber os fundamentos da mesma (Goldfarb, 2001), levando ao advento da ciência moderna.

O vitalismo, característico da Alquimia, é a posição filosófica caracterizada por postular a existência de uma força ou impulso vital sem o qual não se poderia explicar a vida. Essa postura opõe-se às explicações mecanicistas que apresentam a vida como fruto da organização dos sistemas materiais que lhe servem de base.

Os objetivos, a metodologia, a cosmovisão do mundo e da matéria, o perfil profissional, enfim todas as características alquímicas são bem diferentes das novas características trazidas pela química. (Caldeira, 2007) 


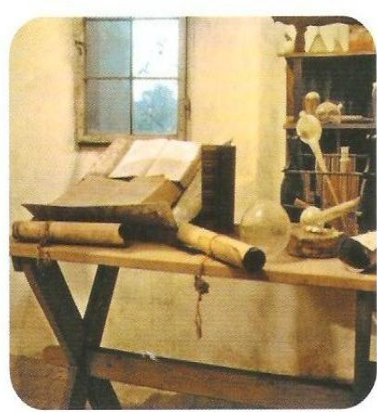

$\triangle$ Papiro sobre uma mesá. O papiro, um tipo primitivo de papel, era muito utilizado por escribas e alquimistas.

\subsection{Alquimia, a precursora da Química}

Após Aristóteles, a Grécia passou por um agitado período político e, gradualmente, a cidade egípcia de Alexandria assumiu a liderança científica da época. Lá, encontraram-se frente a frente a filosofia grega, a tecnologia egípcia e as místicas religiões orientais.

Disso tudo nasceu a Alquimia, uma mistura de ciência, arte e magia, que floresceu durante a Idade Média, tendo uma dupla preocupação: a busca do "elixir da longa vida", que garantiria a imortalidade e a cura das doenças do corpo, e a descoberta de um método para a transformação de metais comuns em ouro (transmutação), que ocorreria na presença de um agente conhecido como "pedra filosofal".

A procura pelo ouro não era motivada por razões econômicas, mas porque ele, devido à resistência à corrosão, representava a perfeição divina. Contudo, muitos realizaram encenações simulando sua transmutação para enriquecer à custa da boa-fé de alguns adeptos da Alquimia.

$\mathrm{Na}$ China, as especulações dos alquimistas conduziram ao domínio de muitas técnicas de metalurgia e à descoberta da pólvora. Os chineses foram os inventores dos fogos de artifício e os primeiros a usar a pólvora em combates no século X.

Nenhum dos dois objetivos da Alquimia foi atingido. Contudo muitos progressos no conhecimento das substâncias provenientes de minerais e vegetais foram obtidos no Ocidente e no Oriente. Prepararam-se substâncias, como, por exemplo, ácido nítrico (chamado na época de aqua fortis) e ácido sulfúrico (oleum vitriolum). Materiais de laboratório foram sendo gradualmente aperfeiçoados.

No século XVI, o suíço Theophrastus Bombastus Paracelsus propôs que a Alquimia deveria preocupar-se principalmente com o aspecto médico em suas investigações. (Isso ficou conhecido como Iatroquímica.) Segundo ele, os processos vitais podiam ser interpretados e modificados com o uso de substâncias químicas. Sua contribuição no diagnóstico e no tratamento de algumas doenças foi digna de nota.

Quadro 2.2- Conteúdos sobre Alquimia em livros didáticos de Química (Peruzzo e Canto, 2006)

Nos quadros 2.4 e 2.5 não aparecem apenas erros conceituais, mas também aparecem erros epistemológicos. No quadro 2.4 que contém trechos do livro 2 (Reis, 2006), aparecem a priori duas páginas retratando a temática ,porém, os equívocos da autora aparecem desde o título e subtítulo do quadro e percorrem todo o corpo textual. O Título é História da Química e o subtítulo é Alquimia, induzindo à continuidade das ciências não esclarecendo que são movimentos distintos (Goldfarb, 2001), como apareceu também no primeiro livro pesquisado (Peruzzo e Canto, 2006), ocorrendo uma quebra entre visões de mundo opostas, não se caracterizando uma evolução de visões de mundo semelhantes. Todo o texto possui informações excessivas e as mesmas não são explicadas. A autora é confusa e prolixa em sua explanação e descrição, em alguns momentos também é contraditória. 


\subsection{Da Alquimia surge a Química}

Em 1597, o alemão Andreas Libavius publicou o livro Alchemia, no qual afirmava que a Alquimia tem por objetivo a separação de misturas em seus componentes e o estudo das propriedades desses componentes.

Em 1661, o irlandês Robert Boyle publicou The sceptical chemist (O químico cético — cético sígnifica "desconfiado", qué só acredita mediante provas), no qual atacava violentamente a concepção aristotélica de quatro "elementos". Para Boyle, elemento é tudo aquilo que não pode ser decomposto por nenhum método conhecido. Esses dois livros são considerados, por alguns estudiosos, o marco inicial da Química.

Há outros estudiosos que creditam a Antoine Laurent Lavoisier o mérito de ser o "pai" da Química. Os trabalhos desse cientista francês, realizados no século XVIII, deram à Química bases mais sólidas. Ele realizou experimentos controlados envolvendo medidas da massa de frascos (incluindo a dos materiais neles contidos) antes e depois de acontecerem reações químicas dentro deles. Uma de suas conclusões, a de que a massa se conserva durante as reações químicas, é considerada por alguns o marco inicial da Química. Vamos estudar essa importante contribuição científica na parte B, capítulo 5 .

No século XIX, os trabalhos de Gay-Lussac, Dalton, Wöhler, Avogadro, Kekulé e outros, cujas conclusões também iremos estudar, deram origem à chamada Química clássica.

No século XX, com o grande avanço tecnológico, presenciou-se uma vertiginosa evolução do conhecimento químico. $\mathrm{O}$ átomo teve sua estrutura interna pesquisada, elementos artificiais foram sintetizados e modernas técnicas de investigação foram desenvolvidas, utilizando conhecimentos de Química, Física, Matemática, Biologia, Computação e Eletrônica.

Quadro 2.3- Conteúdos sobre Alquimia e Química em livros didáticos de (Peruzzo e Canto, 2006)

Alguns exemplos podem ser citados, como a não localização de tempo e espaço em seu texto. No segundo parágrafo a autora afirma o seguinte: “... Aos povos antigos tinham uma visão de mundo mágica e animista..." Observamos que no texto não existe a explicação de quais seriam esses povos, onde eles se encontravam e muito menos a qual época ela se refere.

Outra contradição apresentada no corpo textual é em relação à origem da matéria e das transformações dos materiais que ora é dedicado aos artesãos e ora aos gregos. $O$ texto também não apresenta uma lógica na ordem cronológica de alguns fatos. 


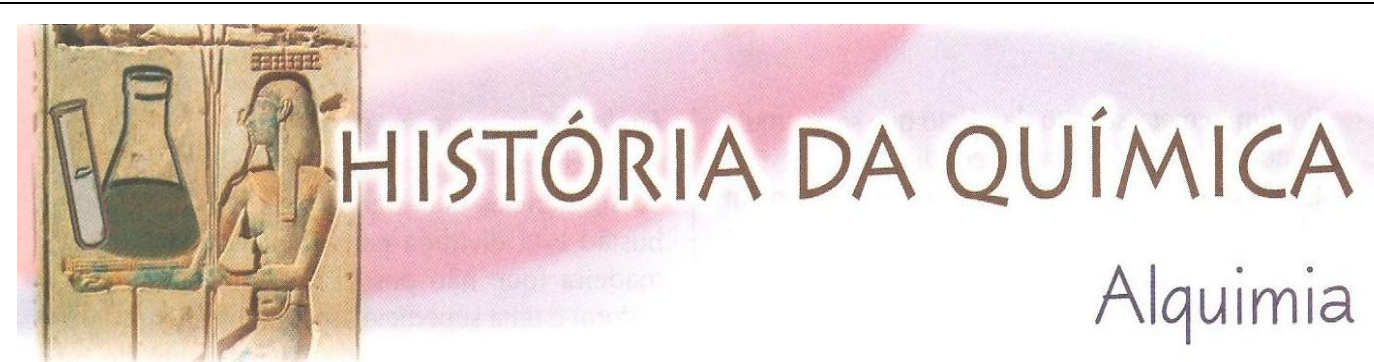

A "arte da khemeia" foi muito além da metalurgia. As comunidades mais antigas produziam cerâmica e vidro, fabricavam gemas artificiais e bebidas alcoólicas, como a cerveja e o vinho, e conheciam as técnicas de manufatura de corantes e pigmentos. Também a pólvora já era produzida e usada pelos habitantes primitivos da região que corresponde hoje à China e à Índia.

Os povos antigos tinham uma visão de mundo mágica e animista, isto é, com tendência a considerar todos os seres da natureza dotados de vida e capazes de agir com determinada finalidade.

As transformações da matéria eram praticadas pelos artesãos; esse conhecimento tinha um caráter sagrado, quase religioso, equivalendo em importância ao conhecimento dos feiticeiros. As técnicas conhecidas pelos artesãos eram indispensáveis ao grupo e eram mantidas em segredo, sendo transmitidas do mestre para o discípulo, ficando restritas ao círculo dos artesãos daquela especialidade.

Havia artesãos que conheciam as técnicas da metalurgia; outros, as técnicas da fabricação de vidro; outros, as da produção de cerâmica; outros, de pigmentos; outros, as da fabricação de cerveja e assim por diante. Um artesão de determinada "especialidade" não conhecia as técnicas utilizadas por um artesão de outra "especialidade"; assim, não se estabelecia nenhuma relação entre elas. Da forma como viviam, não era possível distinguir, como fazemos hoje, as "atividades químicas" das demais atividades.

Nessa visão, a terra, que produz os alimentos e os minérios, é vista como mãe.

Acreditando que toda matéria se comporta como um organismo vivo (teoria conhecida como vitalismo), o processo de transformação dos minerais em metais, por exemplo, deveria ocorrer naturalmente no interior da Terra, de maneira análoga ao desenvolvimento de um feto no útero da mãe. Portanto, o trabalho do artesão especializado em metalurgia que retira o metal do minério com a ajuda do fogo é comparado ao do obstetra, na medida em que ele auxilia o "parto da Terra-mãe".

Nessa concepção, a transformação de minérios em metais era apenas uma questão de acelerar e reproduzir um fenômeno que deveria ocorrer naturalmente no interior da Terra, daí o seu caráter mágico,

A discussão sobre a origem da matéria e o porquê das transformações começou a ser levantada pelos - primeiros filósofos gregos.
A idéia de "elemento" provavelmente surgiu das observações que os filósofos faziam das transformações da matéria. Por exemplo: se uma pedra de azurita (minério de cobre) pode se transformar em um metal avermelhado (cobre), do que essa matéria é constituída? Quem sabe de pedra, ou de cobre, ou das duas coisas ao mesmo tempo?

Ou será que toda matéria pode se transformar numa outra específica mediante determinado número de etapas, de modo que toda matéria existente seja, na verdade, um aspecto diferente de uma mesma matéria básica?

Para os antigos filósofos a resposta à última questão era afirmativa porque desse modo o Universo adquiria uma ordem e uma simplicidade básicas, sob a qual eles teriam certo "controle".

Tales, filósofo da cidade jônica de Mileto, por volta de 625 a.C. a 546 a.C., sugeriu que a origem de tudo estaria num único elemento (palavra usada naquele tempo para indicar um princípio básico do qual toda matéria seria constituída) e estabeleceu que esse elemento único seria a água.

Quando a água líquida é resfriada à temperatura de $0^{\circ} \mathrm{C}$ (sob pressão de $1 \mathrm{~atm}$ ), ela se torna mais densa, o que sugere que os corpos sólidos são formados por condensação de água. Já, ao ser aquecida, a água passa para a fase gasosa, dando a idéia de que 0 ar é uma forma mais rarefeita de água.

Para outro filósofo de Mileto, Anaximandro (610 a.C.-546 a.C.), o único elemento era o que ele chamava de ápeiron, "indeterminado" ou "ilimitado", do qual se originavam os pares de opostos (fogo e água, frio e calor etc.) que constituíam o mundo.

Assim, todas as transformações eram o resultado da interação entre os opostos.

Naquela época o conceito de vácuo não era aceito. Portanto, ninguém acreditava que no espaço entre a terra e o céu pudesse não haver matéria.

Como a parte do espaço que se conhecia continha ar, parecia razoável supor que o ar estivesse espalhado por todo o Universo.

Por isso, Anaxímenes, outro filósofo de Mileto que viveu no século VII a.C., sugeriu que o ar seria o elemento básico e que todas as coisas materiais eram formadas por rarefação ou condensação do ar.

Heráclito (540 a.C.-480 a.C.), filósofo da cidade de Éfeso, raciocinou de maneira diferente: se o que caracteriza o Universo é a mudança constante, é preciso buscar um elemento no qual essa mudança seja mais perceptível. 
Heráclito sugeriu então que o fogo, responsável pela perpétua mutação e fugacidade da matéria, seria o único elemento que constituiria todas as coisas.

Até que o filósofo Empédocles (485 a.C.-425 a.C.), nascido na Sicília, Itália, na época sob domínio grego, propôs substituir a busca do elemento único por um conjunto de quatro elementos: água, ar, fogo e terra (que ele acrescentou).

Esses elementos seriam eternos e movidos pela ação do Amor e do Ódio. A matéria então seria formada pela combinação dos quatro elementos, misturados pelo Amor ou separados pelo Ódio.

Aristóteles (384 a.C.-322 a.C.), da cidade grega de Estagira, reconhecido atualmente como um dos mais importantes filósofos da humanidade, adotou e modificou a teoria dos elementos criada por Empédocles. Segundo Aristóteles, a matéria era formada por uma única essência, que não poderia ter existência isolada (matéria contínua).

Nessa essência da matéria, as quatro qualidades primárias (quente, frio, seco e úmido) se combinariam aos pares, formando dessa maneira os elementos terra, água, ar e fogo.

Os corpos compostos pelas combinações desses elementos poderiam ser convertidos uns nos outros, bastando para isso variar as quantidades relativas das quatro qualidades que entrariam em sua composição.

Segundo Aristóteles, apenas quatro das seis combinações possíveis seriam permitidas:

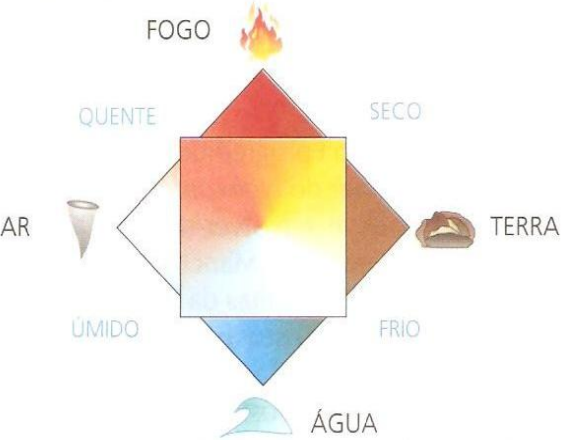

- Quente e seco: combinavam-se para formar o fogo.

Q Quente e úmido: combinavam-se para formar o ar.

* Frio e seco podiam se combinar para formar a terrá.

* Frio e úmido: combinavam-se para formar a água.

Essa idéia de que a matéria seria formada de uma única essência forneceu uma base sólida para uma atividade que começou a se desenvolver nessa época: a alquimia (que se manteve entre os anos 300 a.C. e 1500 d.C.). A palavra alquimia é uma adaptação para o português da palavra árabe alkimiya que, por sua vez, se originou da palavra khemeia (o prefixo al em árabe significa " $\mathrm{O}$ ").

Os alquimistas buscavam, dentre outras coisas, a transmutação dos metais, por exemplo a transformação do chumbo em ouro.
Se toda matéria tivesse a mesma essência, como pregava Aristóteles, bastaria trocar as qualidades (quente, frio, seco e úmido) para transformar um metal em outro. Os alquimistas também acreditavam que os metais, "gerados no útero da Terra-mãe", iam evoluindo ao longo dos anos.

Na escala de "evolução dos metais" estabelecida pelos alquimistas, o chumbo ficava num dos estágios mais baixos, mas, à medida que fosse evoluindo (processo "natural" que levaria milhões de anos), acabaria se transformando em ouro, metal que estava no estágio mais alto dessa evolução. O que se buscava era um meio de acelerar esse processo.

A alquimia árabe foi importante principalmente entre os anos 600 d.C. e 1100 d.C.

O mais famoso dos alquimistas árabes viveu por volta de 720 d.C. a 813 d.C. e é conhecido hoje como Geber, embora seu nome fosse Djabir-Ibn-Hayyan.

Geber fez inúmeros esforços para produzir ouro; finalmente se convenceu de que os metais seriam constituídos pelos princípios enxofre e mercúrio; esses princípios não poderiam ser isolados e seriam responsáveis pelas propriedades dos metais. O segredo da transformação de chumbo em ouro estaria justamente em estabelecer a proporção correta desses dois princípios no ouro e reproduzi-la no chumbo.

Como as tentativas de transmutar os metais não davam resultado, os gregos passaram a acreditar que seria necessário um pó coadjuvante para efetuar a transmutação. E eles denominaram esse pó xerion, palavra grega que significa "seco".

Em árabe essa palavra tornou-se al-iksir, da qual deriva a palavra que conhecemos hoje como elixir.

As cruzadas cristãs, que começaram em 1096, tornaram mais freqüente o contato entre o Leste e o Oeste, e o conhecimento da alquimia começou a infiltrar-se na Europa Ocidental.

A alquimia medieval estava intimamente relacionada com a numerologia, a astronomia, o misticismo e a magia negra, e o seu ímpeto se dirigia à descoberta de um método de "manufaturar" o ouro.

Os alquimistas tornaram-se obsessivos na procura do elixir de Geber, que eles finalmente rebatizaram como a pedra filosofal.

Descobrir como acelerar e reproduzir a "transformação natural dos metais em ouro" significava para o verdadeiro alquimista muito mais do que obter a riqueza do ouro: era a revelação do mais precioso segredo da natureza, e esse segredo só seria revelado a quem tivesse atingido o topo da evolução espiritual,

Assim, ao buscar "a perfeição dos metais" ou "a cura de todas as doenças dos metais", os alquimistas estavam buscando a própria perfeição ou a cura de todas as "doenças da alma".

Conforme acreditavam, quem obtivesse tal revelação seria recompensado com o dom da imortalidade.

Quadro 2.4- Conteúdos sobre Alquimia em livros didáticos de Química (Reis, 2007) 
O excerto tem como subtítulo Alquimia e a autora só começa a explicitar a temática após vinte e seis parágrafos, quase uma folha e meia depois do início do texto. Posteriormente fala de vários filósofos e de toda a Grécia antiga. Quando a autora comenta sobre Alquimia ela faz digressões chegando a apresentar um parágrafo da Grécia no meio da explanação alquímica. A mesma afirma que os alquimistas entre outras coisas queriam a transmutação, mas em ocasião nenhuma a autora especifica que outras coisas eram essas e cita objetivos confusos e inverídicos da Alquimia. A única parte coerente com a história se encontra nos dois últimos parágrafos com a origem e a definição da Alquimia.

Segundo Caldeira (2007) a incoerência apresentada em relação à alquimia foi devido à mesma se apresentar como um período importante, embora discriminado e mal interpretado, para o desenvolvimento da futura ciência química. Sendo despertadas ao longo dos séculos diferentes reações, tanto daqueles ligados na busca de conhecimentos quanto de leigos.

No terceiro livro pesquisado (Quadro 2.5), a temática aparece em um Box denominado Saiba Mais. O título desse quadro é A alquimia e o laboratório- oratório, aparece uma imagem de um laboratório alquímico e sua legenda auto-explicativa. Os equívocos apresentados nesse texto são basicamente a denominação de alquimia como sendo uma ciência que trabalha com operações químicas, na verdade são alquímicas.

O outro erro encontrado nesse fragmento de texto é em relação ao conceito de elemento e substância pura, pois é citado no texto o seguinte: “... Em função das condenações proclamadas pela Igreja Católica durante a Idade Média, o cheiro de enxofre, elemento com o qual os alquimistas faziam muitos de seus experimentos, passou a ser associado ao diabo, sendo os alquimistas acusados de bruxaria..." (Quadro 2.5) O que podemos observar nessa citação é que eles não diferenciam substância de elemento, pois usamos substâncias para realizar experimentos e não elementos químicos. 


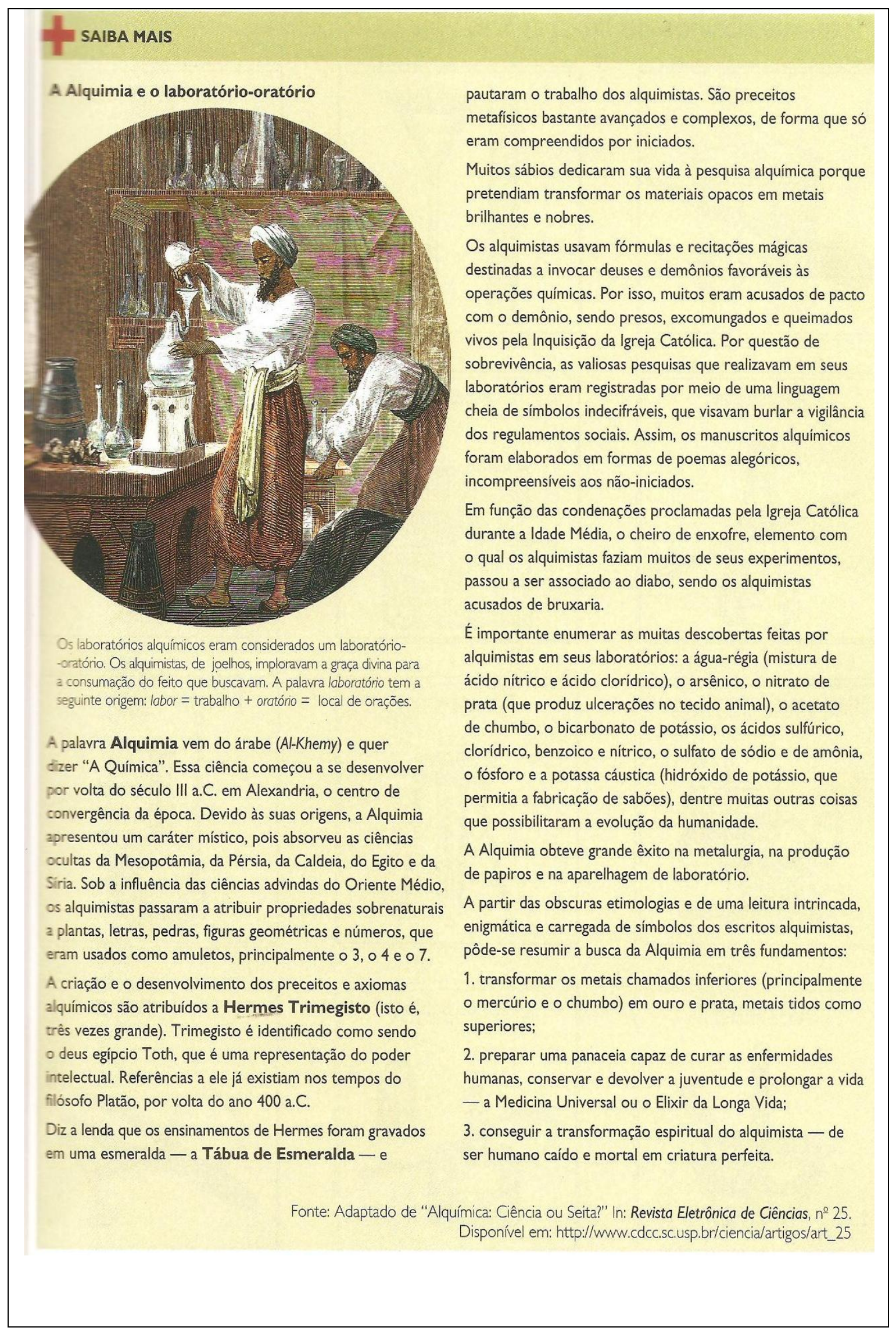

Quadro 2.5- Conteúdos sobre Alquimia que aparecem nos livros didáticos de Química (Enciclopédia do estudante: Química Pura e Aplicada, 2008) 
A partir das análises dos erros conceituais e epistemológicos contidos nos livros didáticos e também nos artefatos culturais estudados nessa pesquisa tornou-se indispensável diferenciar os dois objetos de estudo, que são Alquimia e Química. A Alquimia de acordo com Chassot (1995) e segundo algumas concepções, não pode ser considerada a origem da química, pois se restringia mais a concepções filosóficas da vida. Assim como permanecem dúvidas sobre o que de fato era (ou é) a alquimia, não parece possível definir quando se transformou na química, considerando-se as acepções mais usuais de uma e de outra. Muitos afirmam até que a química teria exterminado a alquimia ao tentar explicar algumas de suas práticas, tirando-Ihe assim o caráter místico.

Nos estudos apresentados por Caldeira (2007) observamos que os ajustes a serem feitos na alquimia seriam tantos que ela seria totalmente desconfigurada de sua essência e de seus princípios, ou seja, deixaria de ser alquimia para ser alguma outra coisa, que até poderia continuar a ser chamada de alquimia, mas que não teria nada em comum com sua antecessora. Ao contrário de tentar realizar estes ajustes na alquimia, a ciência ocidental moderna, trouxe consigo, um novo ramo do conhecimento humano, que tinha em comum com o antigo, apenas o objeto de estudo, a matéria e suas transformações, mas nasceria de certa forma com todos os conceitos definidos e modelados dentro do novo paradigma.

Para compreender melhor as concepções equivocadas dos alunos, os problemas observados nos artefatos culturais e também em livros didáticos que influenciaram em erros conceituais e epistemológicos, resolvemos abordar essa temática na tentativa de minimizar essas incorreções e facilitar o entendimento da matéria e as transformações dos materiais, pois é o ponto em comum entre a Alquimia e a Química. Além de deixar bem claro para os alunos que a Alquimia e Química apresentam distintas visões de mundo ocorrendo assim uma ruptura entre elas e não uma continuidade como fica subentendido em diversos meios presentes na cultura dos alunos. 


\subsection{1- Livros e Filmes}

Um fator que influenciou na escolha do tema foi a série de livros e filmes sobre Harry Potter, da escritora J.K. Rowling (2000a, 2000b, 2000c, 2001, 2003, 2005, 2007a, 2007b), permeados de informações sobre Alquimia e transformações dos materiais, principalmente o primeiro título da série, que se relaciona à pedra filosofal (Harry Potter e a Pedra Filosofal; Quadro 2.6 e Figura 2.1). Os outros títulos também relatam sobre as transformações dos materiais, porém iremos trabalhar neste estudo com o primeiro título apenas, pois retrata explicitamente a temática Alquimia, alquimistas (Nicholas Flamel), imortalidade e a pedra filosofal.

À priori só existiam os livros da escritora, e os filmes baseados na obra da autora gravados pela Warner Bross Pictures (2000-2010), porém com o passar dos anos, foi sendo observado o grande sucesso da série e começaram a lançar novos instrumentos lúdicos que também envolviam essa temática, como Vídeos Games (Figura 2.2), jogos de cartas, Xadrez Bruxo, roupas, chapéus e varinhas mágicas (Figura 2.3) e mais recentemente um parque temático foi inaugurado no mês de Julho de 2010 nos Estados Unidos. O parque do Harry Potter

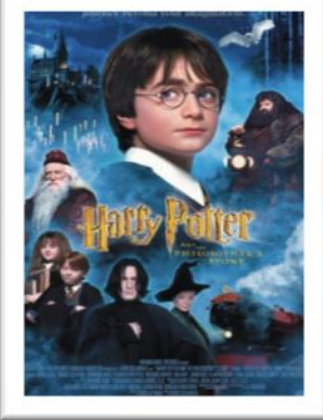
Figura 2.1- Filme Harry Potter e a Pedra Filosofal mostra os cenários da série em tamanho real e desde então está sendo sucesso de bilheterias competindo até com o Complexo Disney. (Figura 2.4)

Um trecho do filme foi destacado para se discutir o tema: "O Antigo estudo da alquimia preocupava-se com a produção da pedra filosofal, uma substância lendária com poderes fantásticos. A pedra pode transformar qualquer metal em ouro puro. Produz também o Elixir da longa vida, que torna quem o bebe imortal".

Quadro 2.6: Trecho do filme Harry Potter e a Pedra Filosofal onde aparece a temática a ser trabalhada. 


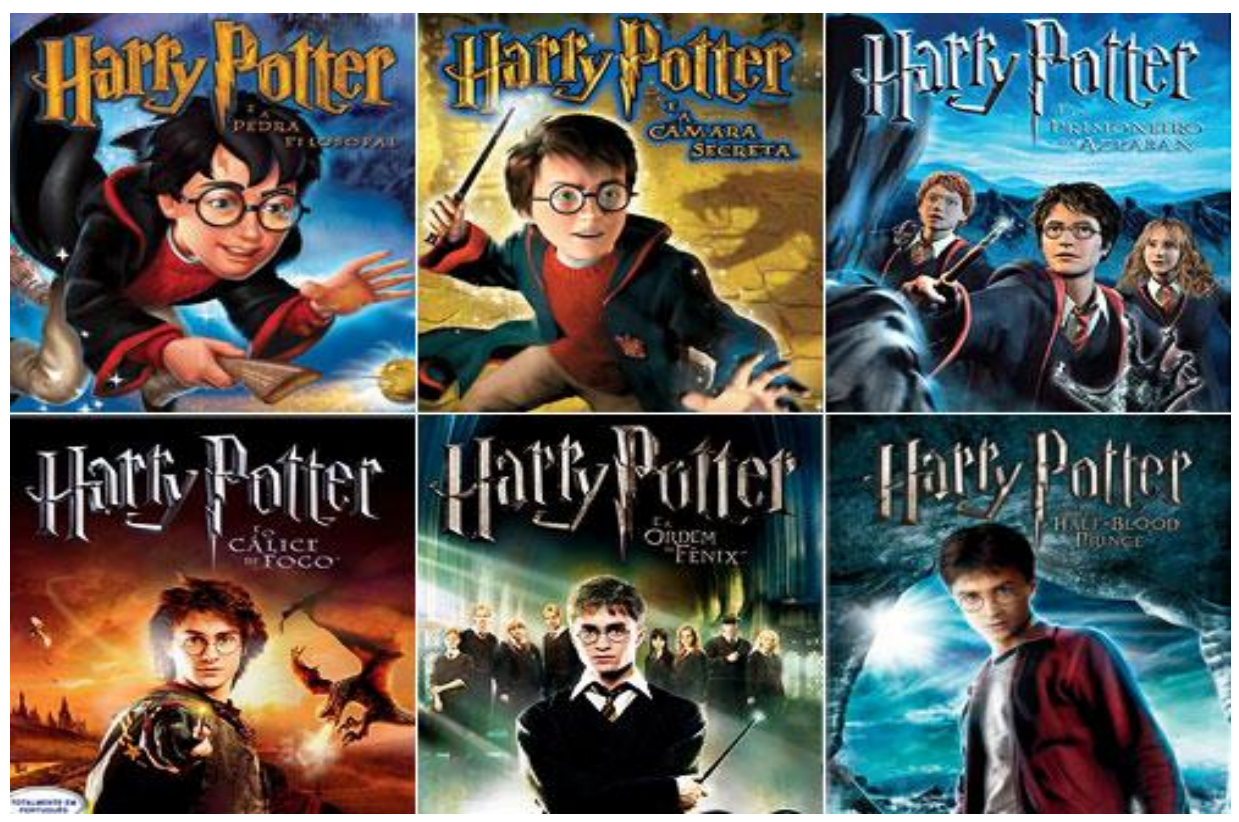

Figura 2.2- Coleção dos Jogos de Play Station de Harry Potter (6 exemplares)

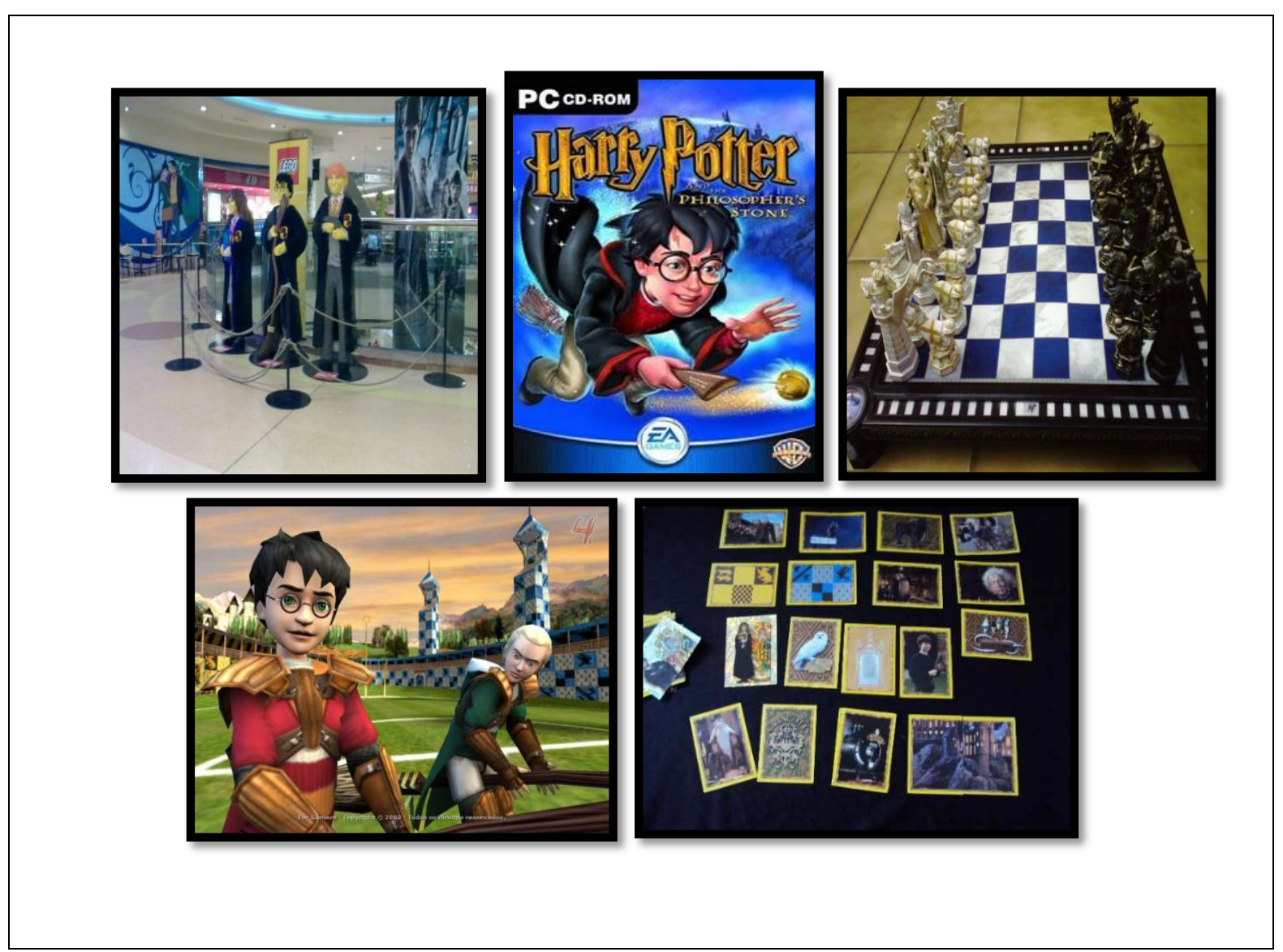

Figura 2.3- Instrumentos Lúdicos adaptados dos filmes Harry Potter 
Hoje em dia, a alquimia está voltando a se evidenciar no dia-a-dia das pessoas com best-sellers como os próprios livros de Harry Potter além do livro O Alquimista, do autor Paulo Coelho e o filme $O$ Código da Vinci. $O$ ponto em comum apresentados em todos os meios culturais citados é em relação ao Alquimista Nicolas Flamel.

Em Harry Potter e a Pedra Filosofal, o famoso alquimista Nicolas Flamel é evidenciado como descobridor e possuidor da Pedra Filosofal, em estudos em conjunto com o diretor Albus Dumbledore e nos livros aparece com 667 anos.

Em O Código da Vinci, Nicolas Flamel também é apresentando, sendo evidenciado como grão-mestre do Priorado de Sião, uma organização que tem como objetivo a proteção do Santo Graal e dos descendentes de Jesus Cristo.

Paulo Coelho, o escritor brasileiro de maior sucesso internacional, também estudioso da alquimia, publicou vários livros que falam sobre o tema, especialmente O Alquimista, Brida, As Valquírias, dentre outras obras onde temas da alquimia aparecem implícitos.

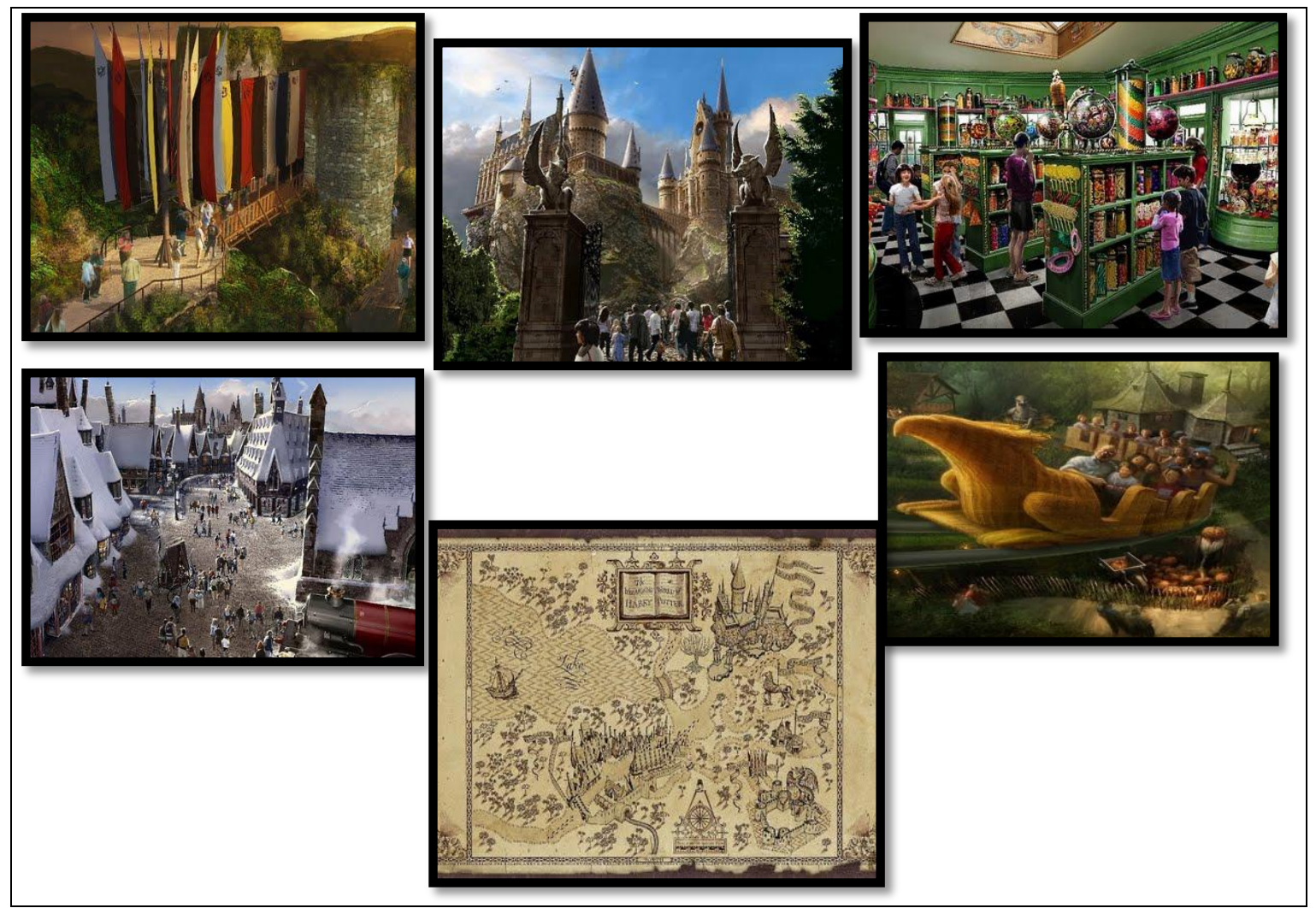

Figura 2.4- Imagens do mais novo parque da Warner Bros: O Reino encantado de Harry Potter 


\subsection{2- RPG (Role Playing Game)}

Muitos desses alunos jogam o Role Playing Game (Jogo de Interpretação de Personagens). Esse é um jogo em que os jogadores assumem os papéis de personagens e criam narrativas colaborativamente. O processo do jogo se dá de acordo com um sistema de regras pré-determinadas, no âmbito das quais os jogadores podem improvisar livremente. As escolhas dos jogadores determinam a direção que o jogo irá tomar.

Os RPGs são, tipicamente, mais colaborativos e sociais do que competitivos. Um jogo típico une os seus participantes em um único time que se aventura como um grupo. Um RPG raramente tem ganhadores ou perdedores. Isso o torna fundamentalmente diferente de outros jogos. Como romances ou filmes, os RPGs agradam porque alimentam a imaginação, sem, no entanto, limitar o comportamento do jogador a um enredo específico. (Cavalcanti e Soares, 2009)

Alguns personagens do RPG remetem à temática da Alquimia, como alquimistas (Quadro 2.7 e Figura 2.5), magos (Quadro 2.8, Figura 2.6) e feiticeiros (Quadro 2.9) ou bruxos, dentre outros.

\section{O ALQUIMISTA}

Em jogos de RPG, o Alquimista é uma classe de personagens típica de cenários de fantasia medieval, dentre os quais se destacam os jogos Dungeons \& Dragons, também chamado de D\&D e jogos eletrônicos como Warlords ou Baldur's Gate. Uma classe dá habilidades (ou perícias) exclusivas para o personagem de cada classe.

Alguns RPGs tiram a atribuição de criar poções e compostos, bem como lidar com eles, dos magos e feiticeiros, passando-a para uma classe mais especializada. Ou ainda, têm a habilidade de manipular os elementos, somente. Ai então surgem os alquimistas. Os "alquimistas" são baseados nos

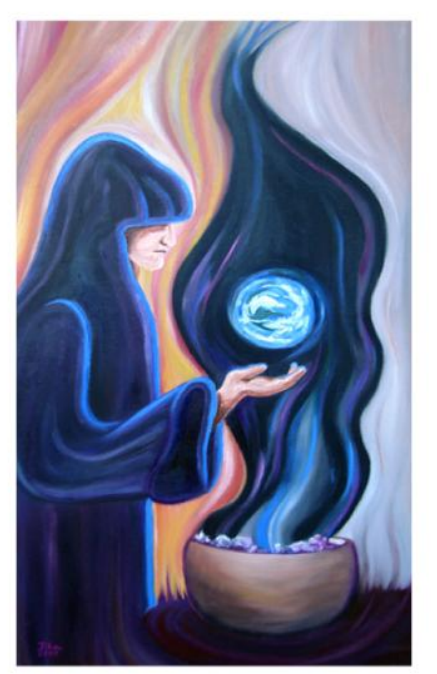

Figura 2.5: Imagem do personagem de um alquimista no RPG. alquimistas históricos, que eram os químicos ou cientistas medievais, em busca de 
objetivos utópicos como produzir a pedra filosofal, material capaz de transformar outros metais em ouro; e da pedra também se retiraria o elixir da longa vida, capaz de prolongar a vida de quem o bebesse. Apesar de falharem nesse objetivo, é sabido que muitos dos experimentos feitos por alquimistas deram base a ciências modernas, como a Química.

Assim, o alquimista, em jogos de RPG, é responsável pela criação de toda sorte de poções e compostos, desde poções de cura, entre outras finalidades, até ácidos, pólvora e outros explosivos. Quando a situação exige que entre em um combate, o alquimista usa seus compostos, jogando ácidos e explosivos em seus inimigos e poções aos seus aliados.

Quadro 2.7: Descrição do personagem do RPG: o Alquimista.

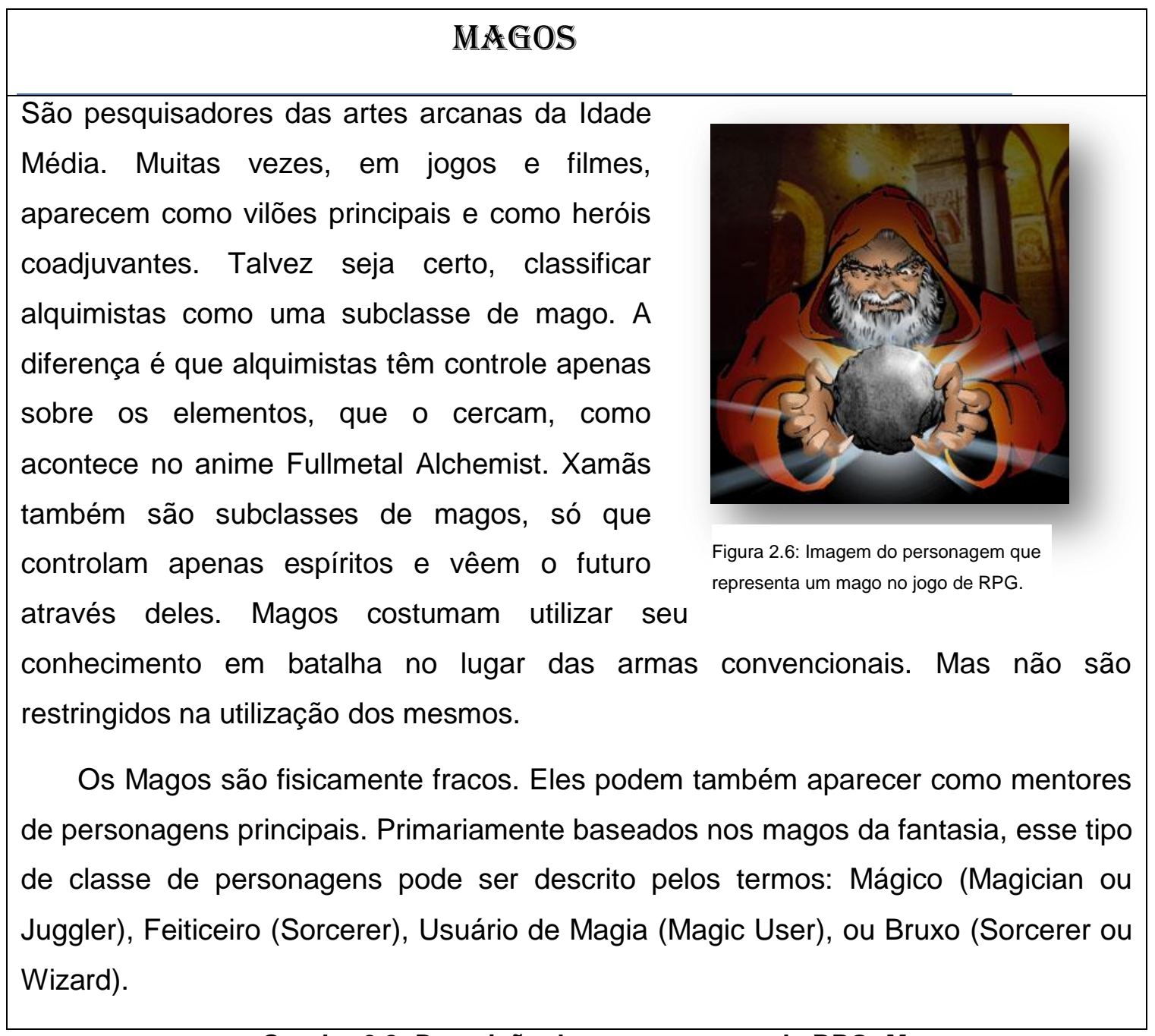

Quadro 2.8: Descrição dos personagens de RPG: Magos. 


\section{FEITICEIROS}

É uma classe de personagens típica de cenários de fantasia medieval, dentre os quais se destacam os jogos Dungeons \& Dragons, mais conhecido como D\&D, e Neverwinter Nights, mais conhecido como NWN. Uma classe dá habilidades (ou perícias) exclusivas para o personagem de cada classe,

Um feiticeiro tem poderes idênticos aos de um mago, com a diferença de que feiticeiros podem lançar magias sem a preparação prévia. Muitas vezes, em alguns jogos e filmes, magos e feiticeiros são considerados como uma só classe. Porém, em jogos, como D\&D e NWN, essas são duas classes distintas. Da mesma forma que magos, feiticeiros usam magia arcana. Um mago prepara poções e magias, diferentemente, feiticeiros têm poder natural, e as criam e controlam da forma que querem sem dificuldades maiores. Porém, em alguns jogos, magos podem aprender magias novas lendo pergaminhos e livros, e feiticeiros estão restringidos à isso. Além do mais, magos nunca se cansarão pelo uso da magia, porém feiticeiros, por usarem magia provinda deles mesmos, têm um grande desgaste físico/mental. Isso pode trazer desvantagens, pois se muito dependentes da magia, quando sem a mesma, ficam indefesos.

A vantagem é que as chances da magia falhar é muita pequena, se consideradas a de um mago. E um feiticeiro mesmo sem conhecimento, tem mais poder e lança suas magias com mais força e as controla com mais facilidade. Um feiticeiro só pode usar essa classe se já nascer com o talento de um feiticeiro, ou seja, com habilidades místicas próprias de sua natureza. Os magos não possuem qualquer poder natural. Apenas os de estudar e aprender a controlá-los.

Feiticeiros costumam utilizar seu conhecimento em batalha no lugar das armas convencionais. Mas não são restringidos na utilização dos mesmos.

Quadro 2.9: Descrição dos personagens de RPG: Feiticeiros

\subsection{3- Desenhos animados, Games e Quadrinhos}

Há vários desenhos animados, filmes e quadrinhos (Figura 2.7), além de jogos de vídeo games (Figura 2.8) que retratam essa temática como o Fullmetal Alchemist que é uma série de mangás criada por Hiromu Arakawa (Figura 2.9). No Brasil, a série é exibida no Animax desde 2005 e, em 2006, no bloco TV Kids de uma 
emissora da TV aberta, em uma versão com censuras. Os DVDs são distribuídos pela Focus Films, enquanto o mangá é publicado pela Editora JBC.

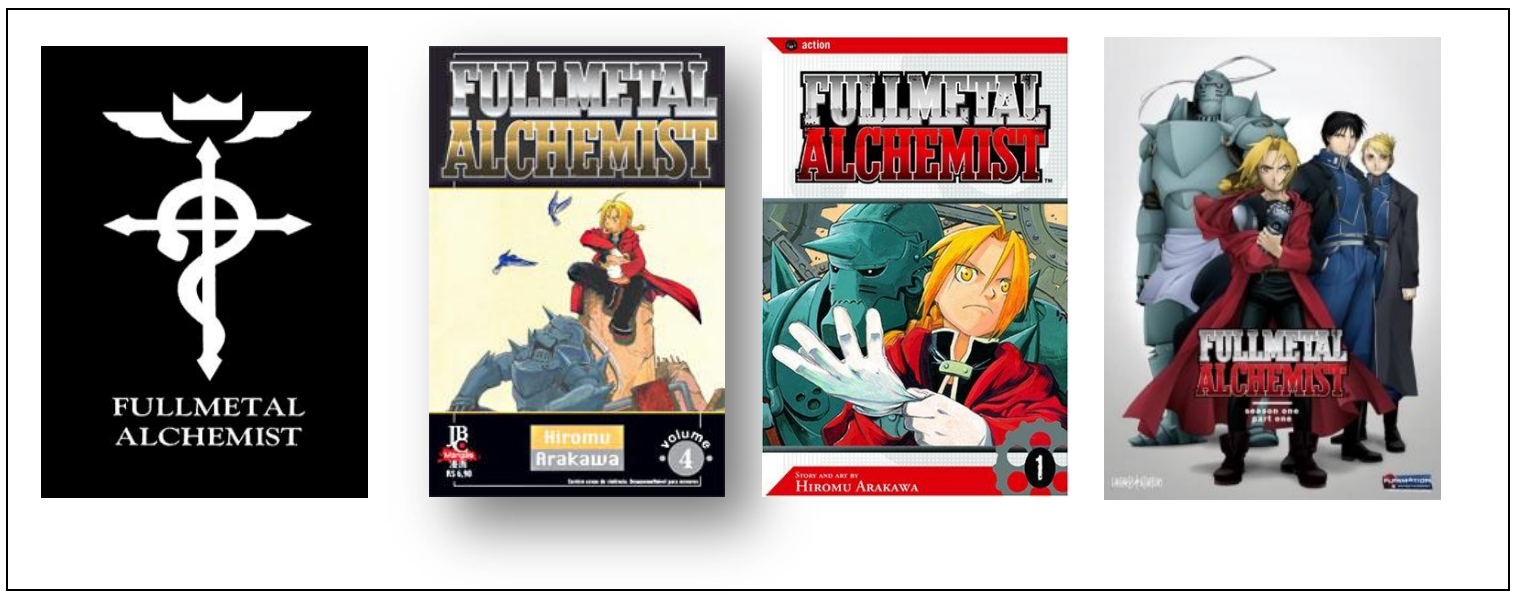

Figura 2.7 - Imagens dos filmes e desenhos animados do Fullmetal Alchemist

Esse mangá japonês Full Metal Alchemist narra à estória dos irmãos Edward Elric e Alphonse Elric, que depois de perderem o braço direito e a perna esquerda, e o corpo (respectivamente, Edward e Alphonse) partem em busca da Pedra Filosofal, a única capaz de recuperar o que foi perdido. Durante a série, diversas referências são mostradas, como Van Hohenheim, antigo alquimista, que no mangá é o pai dos garotos.

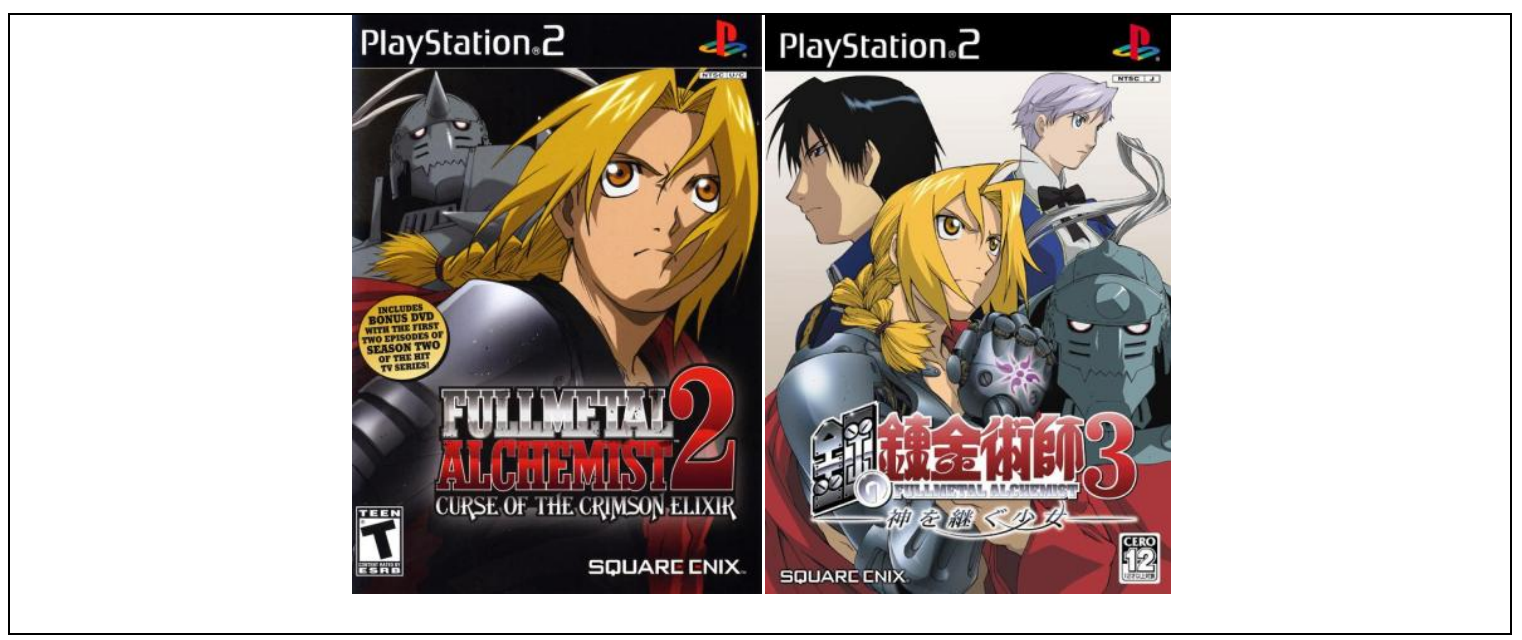

Figura 2.8 - Imagens dos Jogos de Vídeo Games (PlayStation 2) do Fullmetal Alchemist 


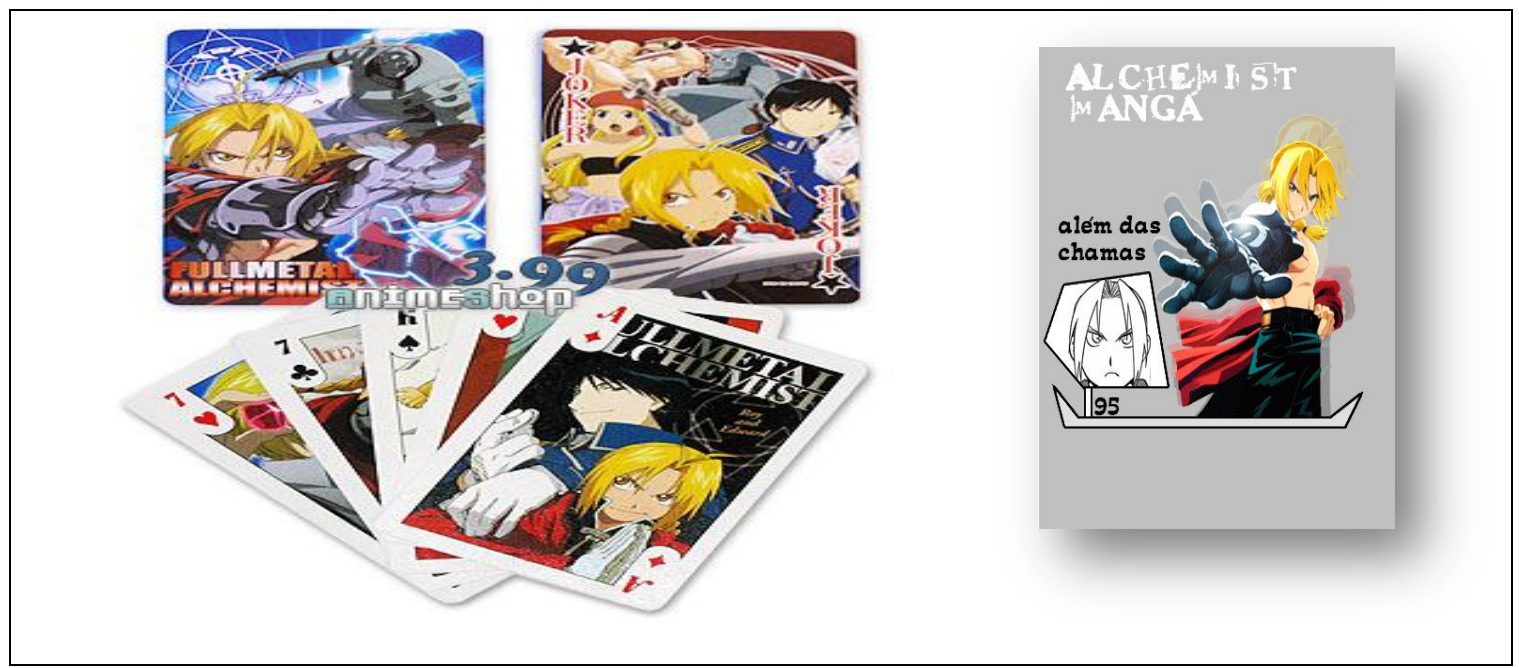

Figura 2.9 - Imagens dos Mangás e de Jogos do Fullmetal Alchemist

\subsection{4- Minisséries e Seriados}

O Pequeno Alquimista foi uma microssérie exibida pela emissora de televisão Rede Globo em quatro capítulos, durante quatro semanas, no período de 26/12/2004 a 16/01/2005.

Esta minissérie foi baseada nos livros $O$ pequeno alquimista (Figura 2.10) e O pequeno alquimista e o elixir da longa vida, de Márcio Trigo. O programa especial dedicado ao público infantojuvenil era escrito por Mariana Mesquita, Cláudio Lobato e Thereza Falcão, com redação final de Mariana Mesquita. A direção era de Ulysses Cruz, a direção geral de Márcio Trigo e a direção de Núcleo de Carlos Manga. Posteriormente no decorrer do ano de 2005 a minissérie foi lançada em forma de dvd. $O$ pequeno alquimista conta a história de João (Daniel Torres), um

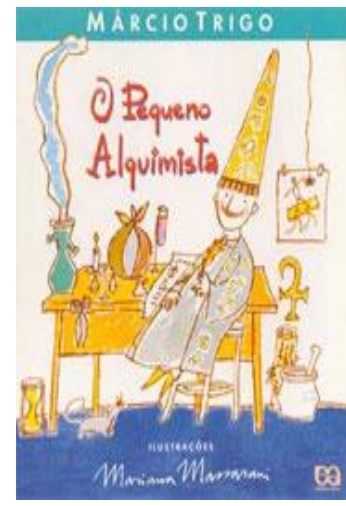

Figura 2.10: Imagens do livro o pequeno menino cheio de idéias que sonha se tornar membro da Associação Alternativa dos Alquimistas, a A.A.A. Seu pai, Aderbal (Alexandre Borges), e seu avô Filolau (Lima Duarte) fazem parte da Associação, sendo Filolau o presidente da A.A.A. 


\subsection{5- Novelas}

A novela Fera Ferida foi uma novela mais antiga apresentada em um canal da rede aberta de televisão, a Rede Globo. Mais recentemente no canal da rede fechada de TV, Viva, também foi reapresentada. Na novela o ator Edson Celulari interpretava um alquimista de nome Raimundo Flamel, em referência clara ao Alquimista Nicolas Flamel.

\subsection{6- Documentários}

Mundos Invisíveis foi um quadro do programa Fantástico exibido pela Rede Globo de Televisão. Apresentado pelo físico brasileiro Marcelo Gleiser, no ano de 2008 Mundos Invisíveis mostrava como cientistas e pensadores chegaram às conquistas do mundo moderno. A série tentava responder uma pergunta em questão, que era: "Do que o mundo é feito?", mostrando como o conhecimento sobre a matéria possibilitou o avanço tecnológico dos dias de hoje.

O programa teve gravações no Brasil e na Europa. Em Paris, por exemplo, o físico Marcelo Gleiser entrevistou o escritor Paulo Coelho a respeito de um de seus livros sobre alquimia, que era o assunto principal do segundo episódio da série. Ele também visitou lugares como a casa onde Albert Einstein morou na Suíça; a biblioteca que contém os escritos originais do filósofo Robert Boyle, em Oxford, Inglaterra; a casa de Dmitri Mendeleiev, o criador da tabela periódica, em São Petersburgo na Rússia; o laboratório de Marie Curie, a maior cientista mulher da história da ciência, ganhadora do Prêmio em Física e em Química em 1903 e 1911.

Mais especificamente no Episódio dois da série, o apresentador trata da temática da Alquimia. O episódio foi denominado de : "Os alquimistas que sonhavam com a vida eterna" . Após a apresentação da série, devido ao seu sucesso o físico lançou um livro intitulado Mundos Invisíveis - Da alquimia à física de partículas, baseado nas mesmas informações da série exibida no Fantástico. O livro conta com a ajuda de textos de apoio do jornalista Frederico Neves, mostrando as teorias de grandes 
pensadores e cientistas - de Aristóteles a Einstein, de Paracelso a Marie Curie, em uma linguagem simples e de fácil compreensão.

\subsection{7- Revistas}

A revista Recreio é uma revista da editora abril com periodicidade semanal voltada para um publico cuja faixa etária envolve dos 6 aos 12 anos. A revista estimula a criatividade, incentiva o gosto pela leitura e ajuda nas pesquisas escolares.

A revista apresenta passatempos, quadrinhos e testes, além de matérias educativas sobre ciência, arte, história e muitos outros assuntos.

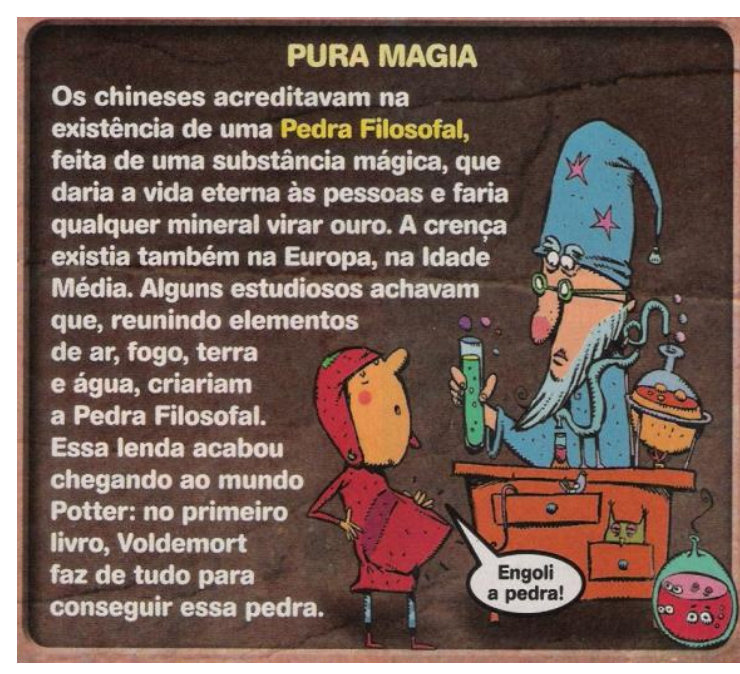

Figura 2.11: Box retirado da revista Recreio tratando da temática da pedra filosofal.

Especialmente na edição de 20 de agosto de 2009 intitulada " $A$ pedra mágica" a revista traz uma reportagem a respeito das pedras superpoderosas, sendo descritas "pedras de verdade que revelam segredos de lugares e épocas diferentes". Entre elas é citada a pedra filosofal, como é mostrada no Box apresentado na Figura 2.11. Observa-se que é feita uma relação direta com a magia e também é explicitado que a pedra aparece no livro Harry Potter e a pedra filosofal.

A partir de todos esses fatores citados anteriormente e dos artefatos culturais apresentados nas seções 2.1.1 a 2.1.7 foi possível desenvolver a temática com os alunos, na tentativa de diminuir essa visão errônea que os mesmos possuíam a respeito da Alquimia, com o passar das etapas de aplicações da atividade lúdica descrita nesse trabalho. Acreditamos também, que dessa forma os educandos progressivamente irão minimizar os erros conceituais e epistemológicos que eles demonstraram ao realizar a análise diagnóstica inicial (Anexo $A$ ). Além da diminuição dos erros (conceituais e epistemológicos), acreditamos também que ao trabalhar a diferença entre Alquimia e Química, e as diferentes visões do mundo sobre as transformações dos materiais, por meio da atividade lúdica, nossos alunos 
irão entender mais facilmente a proposta e o conteúdo, devido à presença da temática no universo cultural deles, fazendo com que ocorra a diminuição do repúdio pela disciplina Química e aumente a motivação dos educandos durante os demais assuntos no decorrer do ano letivo. 
Capítulo 3: OBJETIVOS 
Vários relatos indicam a utilização de jogos como instrumentos mediadores da aprendizagem (Vygotsky, 2005, 2007; Bomtempo, 1999, 1990; Elkonin, 1998; Mellou, 1994, 1995; Piaget, 1990; Chateau, 1987; Winnicott, 1975). Esses autores mostraram que os jogos propiciam a participação ativa dos alunos no processo de ensino, favorecendo condutas que levam ao comportamento exploratório, contribuindo para a solução de problemas e, também, para a aprendizagem de convenções e habilidades sociais.

Considerando essas características das atividades lúdicas como favorecedoras dos processos de ensino e aprendizagem e consonantes com as diretivas oficiais para a educação (Brasil, 1999), a hipótese desta pesquisa é a de que o jogo didático, Autódromo Alquímico (Santana e Rezende, 2009; Santana, 2006), que neste estudo é um processo que envolve sete etapas (vide seção 7.2), propicie um ambiente de aprendizagem colaborativo entre os estudantes, favorecendo aos alunos serem sujeitos do processo, com mediação do professor.

Assim, os objetivos do estudo conduzido durante esta Dissertação são os de:

* Criar, desenvolver, aplicar e avaliar uma atividade lúdica planejada e elaborada na forma de um jogo didático.

Estes objetivos se desdobram nos seguintes objetivos específicos:

* Criar, desenvolver e aplicar o Autódromo Alquímico, um jogo didático concebido para mediar o conhecimento das transformações dos materiais, considerando aspectos do universo cultural de alunos do último ano do Ensino Fundamental;

* Verificar a opinião dos estudantes sobre a atividade;

* Avaliar o Autódromo Alquímico, para verificar se, com seu emprego, será possibilitado, a estes alunos, ressignificar os conceitos abordados, pela distinção entre duas formas de pensar sobre as transformações dos materiais, a da Alquimia e a da Química 
- Analisar se as Funções Psicológicas Superiores como linguagem, pensamento, imaginação, emoção, atenção, memória, abstração e percepção, são desenvolvidas através da mediação das atividades por meio de recursos lúdicos, ou são apenas aprimoradas pelo jogo, já que a princípio já podem existir. 
Capítulo 4: O Universo Lúdico 


\section{1- Atividades Lúdicas no contexto escolar}

Lúdico é um termo derivado do Latim ludu, significando jogo ou adjetivo referente a jogos, brinquedos, divertimentos ou passatempos e os qualificando enquanto componentes do comportamento humano. Já as atividades lúdicas são todo e quaisquer movimentos cujo objetivo precípuo seja o de produzir prazer quando de sua execução, ou seja, divertir o praticante (Soares, 2008). Constituem-se em elementos muito valiosos no processo de apropriação do conhecimento por favorecerem o desenvolvimento de habilidades no âmbito da comunicação, das relações interpessoais, da liderança e do trabalho em equipe utilizando a relação cooperação/competição em um contexto formativo (Moreira, 2008; Santana e Rezende, 2010a, 2010b; 2007). Essas atividades são uma metodologia facilitadora do aprendizado porque, através delas, é possível a simulação de situações cotidianas, socialização de pessoas, desenvolvimento de habilidades diversas e da própria mente. Essas atividades induzem a formação de ambientes desafiadores, capazes de estimular o intelecto proporcionando a conquista de estágios mais elevados de raciocínio.

O uso desse tipo de atividade para o ensino não é algo recente. Os filósofos gregos já se utilizavam desse expediente para ajudar seus aprendizes (Moraes e Rezende, 2009). Assim, jogos podem e devem ser utilizados como uma ferramenta importante no ensino e na aprendizagem de uma forma geral, fazendo parte da educação de crianças, adolescentes e jovens (Santana, 2006). Freqüentemente, essas atividades lúdicas também ajudam a desenvolver diversas habilidades, desde as que mobilizam preferencialmente os níveis cognitivos mais elementares como a memorização e repetição, até as que envolvem aqueles mais elaborados (Piaget, 1990; Vygotsky, 2007), tais como a criticidade, liderança em grupo, o raciocínio lógico.

Diversos teóricos precursores de métodos ativos da educação (Winnicott, 1975; Chateau, 1987; Piaget, 1990; Mellou, 1994, 1995; Elkonin, 1998; Huizinga, 1996; Wallon, 2000; Vygotsky, 2005, 2007) frisaram a importância que os métodos lúdicos proporcionam à educação de crianças e adolescentes, pois nos momentos de maior 
descontração e desinibição, oferecidos pelos jogos, as pessoas se desbloqueiam e descontraem, o que proporciona maior aproximação, uma melhoria na integração e na interação do grupo, facilitando a aprendizagem (Santana e Wartha, 2006).

As atividades lúdicas, mais do que serem aceitas como rotina na educação de alunos do Ensino Fundamental e Médio, cuja faixa etária varia entre 12 e 18 anos são uma prática privilegiada para uma educação que objetive o desenvolvimento pessoal e a atuação cooperativa na sociedade (Santana e Wartha, 2006). São, também, instrumentos motivadores, atraentes e estimuladores do processo de ensino e aprendizagem e da construção do conhecimento, desenvolvendo também funções psicológicas básicas que, conseqüentemente, dependendo do tipo de atividade, se transformarão em funções psicológicas superiores (Vygotsky, 2007; Santana e Rezende, 2010a). A ação lúdica pode ser definida, de acordo com Soares (2004), como uma ação divertida, seja qual for o contexto lingüístico, desconsiderando o objeto envolto na ação. Se há regras, essa atividade lúdica pode ser considerada um jogo.

Em síntese, existem, no uso dos jogos, dois aspectos primordiais, um referente à afetividade, expresso durante a ação e, outro, referente aos aspectos cognitivos, no qual $o$ jogo proporciona avanços nos processos de aprendizagem e desenvolvimento.

Através das inter-relações professores e alunos e entre alunos e alunos, pode-se atribuir certa importância no que se refere às imagens e modelos (Moreira, 1997). Nesse caso, as relações serão facilitadas através das atividades lúdicas que servirão de elemento mediador entre os sujeitos envolvidos na ação. A atividade mediada pelo educador ou por outro educando mais experiente determinará a aprendizagem, pois o que o aluno aprenderá em colaboração com outra pessoa poderá ser capaz de fazer, mais adiante, de maneira independente (Moraes e Rezende, 2009).

Por outro lado, é importante ressaltar que os processos de aplicação das atividades lúdicas possuem aspectos: positivos e negativos (Figura 4.1). Assim, essas atividades contribuem para aperfeiçoar, no educando, habilidades de participar, criticar, dialogar, interagir, agir de maneira autônoma, cooperar, perseverar, respeitar o outro. Por outro lado, para determinados alunos poderão ser instrumento de discriminação, competição e exacerbação do individualismo. 


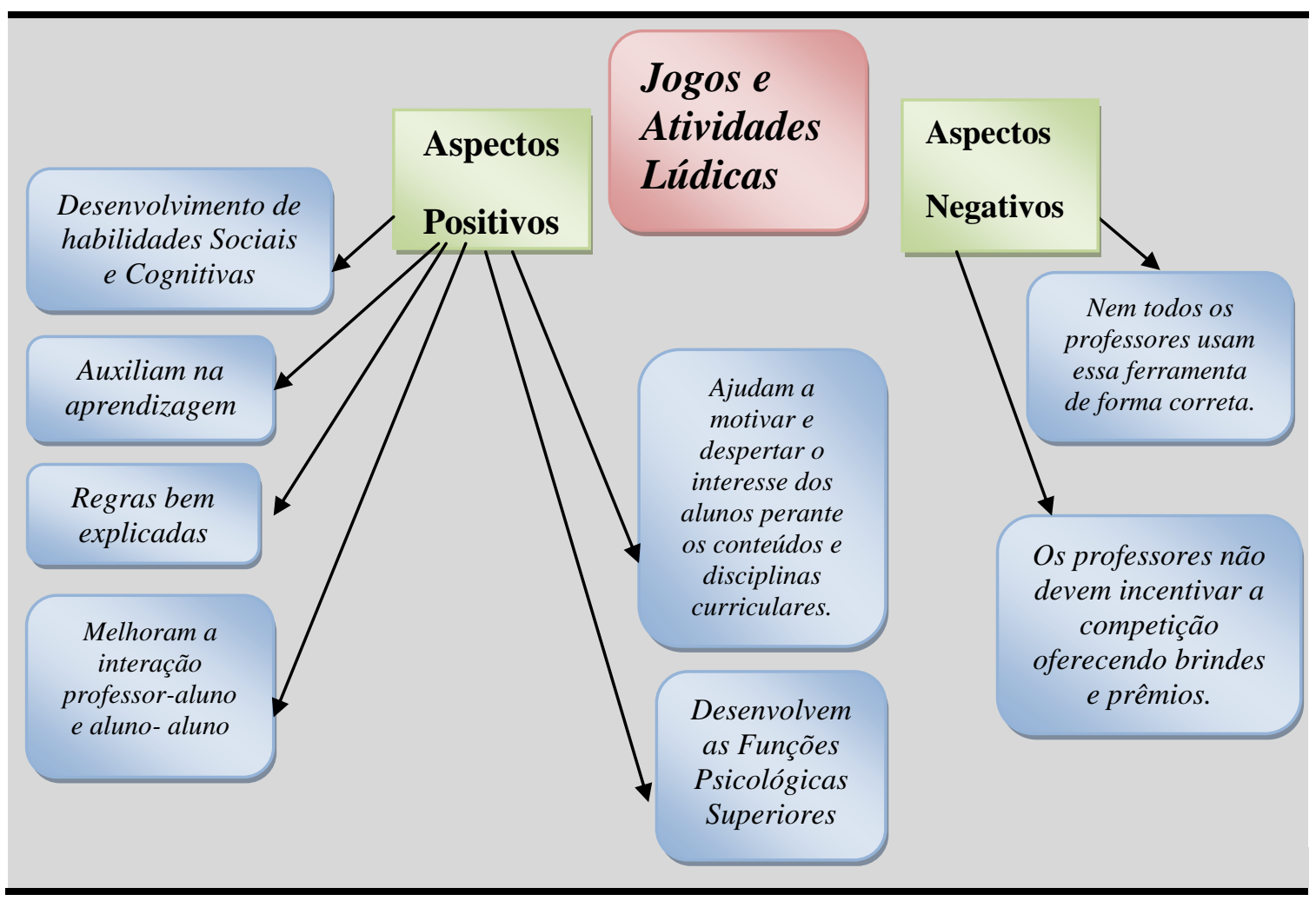

Figura 4.1: Fluxograma descrevendo aspectos positivos e negativos da utilização das atividades lúdicas no ensino.

As atividades lúdicas, quando utilizadas no contexto escolar, podem determinar o predicado das inter-relações e as regras fixadas definem a natureza dos processos de ensino e aprendizagem.

Entre as atividades lúdicas, definimos o jogo como sendo uma atividade lúdica com regras estabelecidas (Soares, 2004). No contexto educacional, o jogo, de acordo com Valenzuela (2005), deverá possibilitar o aprendizado com os outros, a participação conjunta, a responsabilidade e o respeito pelos demais, condições fundamentais para o crescimento individual. Nessa tendência, as orientações do professor devem favorecer a estimulação do crescimento da autonomia e a relação desta com a integração do educando, no contexto de sua coletividade.

Nesta pesquisa definimos atividade lúdica como todo o processo metodológico que consistiu em sete etapas de execução, desde a análise diagnóstica inicial (anexo A) até a análise diagnóstica final (Anexo F). E consideramos o jogo como a fase de aplicação do tabuleiro "Autódromo Alquímico". O jogo "Autódromo Alquímico", enquanto instrumento de intervenção na aprendizagem das Ciências Naturais, é visto como uma atividade que tem características próprias e cujo 
conteúdo pode colaborar para o pleno desenvolvimento de habilidades conceituais e atitudinais do aluno, além de representar um meio para se socializarem os demais conteúdos curriculares (Santana e Rezende, 2007). Logo, esses dois elementos trabalhados, tanto a atividade lúdica, quanto o próprio jogo, fazem parte do universo lúdico que permeia o nosso trabalho.

\section{2- A Influência das Atividades Lúdicas na Aprendizagem}

Segundo Negrine (1998 apud Cabrera e Salvi 2005), brincar não significa que o jovem ou o adulto volte a ser criança, mas é um meio que possibilita ao ser humano integrar-se com os outros, consigo mesmo e com o meio social. Nas atividades lúdicas, as condições de seriedade, compromisso e responsabilidade não são perdidas, ao contrário, são sentidas, valorizadas e, por conseqüência, ativam o pensamento e a memória, além de gerar oportunidades de expansão das emoções, do prazer e da criatividade. O estudo de Negrine (1998) mostra que as atividades prazerosas atuam no organismo causando sensação de liberdade e espontaneidade. Conclui-se que, devido à atuação das atividades prazerosas no organismo, as atividades lúdicas facilitariam a aprendizagem por sua própria acepção, pois os mecanismos para os processos de descoberta são intensificados.

De acordo com Melo (2005), vários estudos a respeito de atividades lúdicas vêm comprovar que o jogo, além de ser fonte de prazer e descoberta para o aluno, é a tradução do contexto sócio-histórico refletido na cultura, podendo contribuir significativamente para o processo de construção do conhecimento do aluno como mediador da aprendizagem. Aprender e ensinar brincando, enriquece as visões do mundo e as possibilidades de relacionamento e companheirismo, de socialização e troca de experiências, de conhecimento do outro e respeito às diferenças e de reflexão sobre as ações (Cabrera e Salvi, 2005). O lúdico é um importante instrumento de trabalho no qual o professor deve oferecer possibilidades para a elaboração do conhecimento, respeitando as diversas singularidades. Essas atividades, quando bem exploradas, oportunizam a interlocução de saberes, a socialização e o desenvolvimento pessoal, social, psicológico e cognitivo. 
Esse conjunto de fatores é essencial para a construção de uma relação plural entre educadores e educandos, condição básica para a constituição de uma prática educativa de qualidade e para a descoberta e apropriação do "mundo dos saberes e dos fazeres", das palavras, dos números, das idéias, dos fatos, dos sentimentos, dos valores, da cidadania e dos sonhos pelos educandos.

Os recursos lúdicos correspondem naturalmente a uma satisfação idiossincrática, pois o ser humano apresenta uma tendência lúdica, desde criança até a idade adulta. Por ser uma atividade física e mental, a ludicidade aciona e ativa as funções psico-neurológicas e os processos mentais. O ser que brinca e joga é também um ser que age, sente, pensa, aprende e se desenvolve intelectual e socialmente (Cabrera e Salvi, 2005; Soares, 2004). A aprendizagem será influenciada devido à relação emocional e pessoal que o estudante estabelece quando está jogando, tornando-se sujeito ativo do processo de ensino e aprendizagem no qual se insere diretamente (Santana e Rezende, 2007b). Como as atividades lúdicas integram e acionam as esferas motora, cognitiva e afetiva dos seres humanos, ao trabalharem 0 lado emocional do aluno, influenciam diretamente o processo de ensino e aprendizagem (Santana \& Rezende, 2007).

O jogo é caracterizado como um tipo de recurso didático-educativo que, de acordo com Cunha (2004), pode ser utilizado em momentos distintos, tais como: na apresentação e desenvolvimento de um conteúdo ou na ilustração de seus aspectos relevantes, na avaliação de conteúdos já desenvolvidos ou, ainda, na revisão ou síntese de conceitos importantes.

Em síntese, as atividades lúdicas não levam simplesmente à memorização mais fácil do assunto abordado, mas induzem o aluno a raciocinar, a refletir. Além disso, essas práticas contribuem para o desenvolvimento de habilidades, pois o lúdico é integrador de várias dimensões do aluno, como a afetividade, o trabalho em grupo e das relações com regras pré-definidas, promovendo a construção do conhecimento cognitivo, físico e social. 


\section{3- O uso de Atividades Lúdicas nas Ciências da Natureza}

Entendemos a Química como disciplina pertencente às Ciências da Natureza, sendo fundamental para a construção de um espaço de apropriação e desenvolvimento cultural e escolar, admitindo, como inerente à área, a tarefa de facilitar, promover e garantir a apreensão dos conteúdos pelos educandos. Santos e Schnetzer (2003) enfatizam que os educadores químicos deverão adotar uma prática que incida de forma global no desenvolvimento do sujeito, do cidadão crítico, ativo e participativo.

Ainda de acordo com Santos e Schnetzer (2003), o professor de Ciências Naturais deverá ser capaz de planejar, ordenar e sistematizar sua prática pedagógica, de modo que esta venha ao encontro dos conteúdos específicos da Química, além de intencionar de maneira crítico-reflexiva a construção de um ambiente que favoreça a colaboração para a educação. Tais objetivos devem cumprir a função de formar o cidadão para a atuação e intervenção na vida pública (Brasil, 1999).

Ao utilizar-se do jogo como recurso nas Ciências Naturais, os mesmos poderão vir a contribuir para o desenvolvimento de diversas habilidades fundamentais dentre as quais a socialização, a autonomia, as aprendizagens instrumentais básicas e a melhoria das possibilidades expressivas, cognitivas, comunicativas, lúdicas e de movimento. Para isso, o professor deve guiar-se por orientações metodológicas bem definidas.

Segundo Valenzuela (2005), quando se trata de atividades lúdicas e jogos o professor deve ser aberto, flexível e motivador, de modo a buscar o desafio e o diálogo com seus alunos, fazendo com que ocorra espontaneidade, no contexto educacional, com regras progressivamente mais complexas.

O professor também deve direcionar sua participação e intervenção, no sentido de elaborar e estruturar as normas que nortearão as atividades e que garantirão a prevalência dos interesses do grupo (Santana e Rezende, 2008a, 2008b).

Para que se efetive tal processo, faz-se imprescindível ao educador considerar o seu papel de mediador entre o aluno e as novas aprendizagens (Moraes e Rezende, 2009). Esse profissional, ao oferecer materiais potencialmente significativos e 
adaptados aos diferentes níveis de desenvolvimento, interesse e motivação dos aprendizes, prepara um ambiente que favorece a predisposição ativa dos educandos para a aprendizagem. Outro aspecto socializador fundamental, como já foi citado anteriormente, é a relação entre os pares, marcada pelas interações já estabelecidas com os adultos. Esse aspecto é explicado de acordo com Garófano e Caveda (2005), pois, a relação com 'o igual' é muito significativa apresentando um momento em que o indivíduo dedicando menos tempo às figuras de apego, exibe maior autonomia.

As atitudes e orientações do professor em sua mediação realizada a partir da atividade lúdica devem contribuir para o crescimento da autonomia pessoal e explicitar a íntima relação do indivíduo com o coletivo em que se insere. Desse modo, as atividades lúdicas devem possibilitar o aprendizado com os outros, porque a participação solidária, o respeito mútuo, a cooperação e a perseverança são habilidades atreladas ao desenvolvimento pessoal.

É nesse universo que o aluno vivencia situações diversificadas que favorecem o aprendizado e o diálogo, podendo-se concluir que a natureza do jogo é determinada por suas regras e, conforme Valenzuela (2005), a determinação dessas poderá desenvolver um ambiente onde prevaleça a cooperação, a solidariedade, a aceitação ao outro e reafirmar valores que se contrapõem à natureza desses. 
Capítulo 5: SOBRE O JOGO 
O uso de recursos metodológicos como atividades lúdicas, brinquedos e, principalmente, jogos na educação vem sendo pesquisado e analisado por vários estudiosos e teóricos da atualidade. Além da influência no processo de ensino e aprendizagem, os jogos são instrumentos de intervenção social de crianças e, principalmente, de adolescentes, facilitando assim o seu desenvolvimento social e conseqüentemente cognitivo.

Atualmente, é comum nos depararmos com duas teorias contemporâneas distintas em relação aos jogos, a Teoria Piagetiana e a Teoria Histórico- Cultural ou Teoria Vygotskyana. Apesar de suas diferenças e singularidades, ambas as teorias discutem o papel do jogo como um significativo recurso pedagógico presente no cenário educacional.

Neste estudo, iremos nos embasar na concepção de jogo segundo a perspectiva Histórico-Cultural, que começou a se destacar no início do século $X X$, na União Soviética. Seus pesquisadores faziam parte de uma escola de psicólogos que estudava o papel da educação e, especificamente, o desenvolvimento de crianças e adolescentes nesse processo. Os mesmos tinham como objetivo precípuo o desenvolvimento pleno das capacidades humanas das crianças e dos adolescentes para a construção de um novo modelo de sociedade mais justo e digno. Entre os estudiosos dessa Teoria, encontramos Vygotsky (1999; 2001; 2005; 2007), Leontiev (1978), Elkonin (1998; 2000) e Luria (1992).

\section{1- TeOria Histórico-Cultural E OS Jogos}

O precursor da Teoria Histórico-Cultural foi o psicólogo russo Lev Vygotsky. Vygotsky atribuiu enorme importância ao papel da interação social no desenvolvimento do ser humano. Ressaltamos que uma das contribuições mais significativas das teses que formulou é a tentativa de explicitar como o processo de desenvolvimento cognitivo é socialmente construído (Vygotsky, 2007).

Segundo Vygotsky (2005), o aprendizado humano pressupõe uma natureza social específica e um processo através do qual os sujeitos interagem na vida dos que os cercam, principalmente em relação ao aspecto cognitivo, ocorrendo esse processo através da demonstração ou exemplos de pessoas mais experientes (Vygotsky, 
2007), ou seja, pela internalizarão das prescrições de adultos envolvidos na interação.

Gradativamente, através da interação com indivíduos mais experientes, o sujeito vai desenvolvendo sua capacidade simbólica e tornando-se mais consciente de sua própria experiência. Esse fator impulsionará a aquisição de formas puramente humanas de inteligência prática e abstrata. As interações da criança com outras pessoas presentes em seu ambiente irão desenvolver habilidades cognitivas como a fala interior, o pensamento reflexivo, crítico e o comportamento voluntário. (Vygotsky, 2007).

O segundo psicólogo sobre o qual faremos uma breve explanação é Alexei Leontiev. Leontiev trabalhou com Vygotsky, por volta da década de 20 do século passado, estudando a memória e a atenção deliberadas. Desenvolveu a Teoria da Atividade ou Teoria da Atividade Principal, que faz conexão entre o contexto social e o desenvolvimento. A Teoria da Atividade de Leontiev (1978) tornou-se a base estrutural de muitas pesquisas realizadas na Rússia, particularmente nas áreas da brincadeira e da aprendizagem

Leontiev (1978) formulou o conceito de atividade como sendo um sistema coletivo derivado de um objeto e de um motivo, realizando-se através de ações individuais dirigidas por objetivos. Essas ações, por sua vez, seriam realizadas através de operações rotineiras, dependendo das condições da ação, facilitando assim o desenvolvimento.

A atividade é sempre caracterizada por sua orientação para o objeto, preenchendo um propósito específico. A força de direção da atividade é seu motivo, direcionador da atividade. Como Leontiev afirmou: "não pode haver atividade sem motivo". (Leontiev, 1978)

A ação é o componente básico da atividade sendo um meio de realizá-la e, conseqüentemente, de satisfazer o motivo. O traço característico de uma ação é o fato de que é sempre orientada para um objetivo, almejando a satisfação de um objetivo particular. A parte operacional de uma ação refere-se às circunstâncias específicas que cercam sua execução. As operações constituem o meio pelo qual uma ação é realizada. 
Outro psicólogo de destaque no contexto da teoria Histórico- Cultural é Daniil B. Elkonin. Elkonin (1998) foi aluno de Vygotsky e deu continuidade as suas idéias, escrevendo especificamente a respeito da psicologia que envolve o processo trabalhado no jogo. Sua teoria foi publicada no livro intitulado "Psicologia do Jogo".

Segundo Elkonin (1998), o jogo é uma atividade em que se reconstroem as relações sociais. A criança joga a partir de ações presentes na cultura em que está inserida, observando, principalmente, os adultos em suas atividades cotidianas e crianças mais velhas. Elas representam, em seus jogos, a vida adulta, atividades que ainda não realizam na infância, surgindo, assim, o que Elkonin (1998) define como sendo o jogo protagonizado.

O jogo protagonizado, de acordo com Elkonin (1998), caracteriza-se por atividades que envolvem uma situação imaginária, por meio das quais as crianças necessitam da representação de algum papel. Sendo assim, essa forma de jogo depende do contexto histórico-cultural no qual a criança está inserida e, também, está diretamente relacionada às interações sociais da criança com os adultos que mediam suas ações, pois a criança representa aquilo que ela observa na sua vivência. Esse tipo de jogo surge da grande diferença entre aquilo que a criança gostaria de ser e o que ela pode ser. Assim, ela representa, através do jogo, os papéis dos adultos de seu interesse. $\mathrm{O}$ jogo é o mediador de todo esse processo.

Elkonin (1998) discute, também, a questão da divisão do desenvolvimento infantil em estágios, de acordo com o desenvolvimento de determinados aspectos cognitivos, originados da universalização do acesso à educação escolar, levando o indivíduo, como um ser pertencente ao gênero humano, a desenvolver plenamente suas habilidades.

O quarto e último psicólogo que discute sobre essa temática e é foco de nosso estudo é Alexander Luria. Em meados da década de 20 do século XX, Luria conheceu Vygotsky, que o influenciaria grandemente, juntamente com Leontiev. Esses pesquisadores lançaram um projeto inovador, que iria desenvolver uma nova psicologia. Enfatizando o papel do mediador cultural, particularmente da linguagem, Luria (1992) também escreveu a respeito de das funções psicológicas superiores (FPS): emoção, imaginação, percepção, memória, pensamento, linguagem, abstração, generalização e criatividade. O aprimoramento dessas funções é de fundamental importância para o desenvolvimento das crianças e adolescentes. 
Vygotsky (2005; 2007), Elkonin (1998), Leontiev (1988) e Luria (1992) formaram uma corrente da Psicologia que estudou o desenvolvimento humano e, como parte desse estudo, analisou o papel do jogo na educação e no processo do desenvolvimento infantil, sendo esses últimos o nosso foco de estudo. 0 desenvolvimento de crianças e adolescentes é influenciado por mudanças históricas. As crianças de hoje não se desenvolvem, não agem e nem pensam da mesma maneira que as crianças do século XIX ou do século XX. As condições culturais, econômicas, sociais e históricas são fatores decisivos nesse processo.

Dentro desse quadro teórico é que o jogo é inserido na educação, para esses autores. Vygotsky (2005; 2007), Elkonin (1998) e Leontiev (1988) concordam que o jogo é precursor da aprendizagem, um veículo para o aprimoramento do caráter social, emocional e intelectual dos educandos e, também, proporciona 0 desenvolvimento de habilidades e das FPS, no período do Ensino Fundamental como um todo, que envolve crianças na faixa etária de 2 a 15 anos, incluindo infância e adolescência, sendo nosso foco este último estágio.

\section{2- Os Jogos e O Desenvolvimento de Crianças e Adolescentes}

As brincadeiras e jogos são vistos de formas completamente distintas por crianças e adolescentes, pois os mesmos apresentam concepções, objetivos, idéias e visões de mundo diferentes. Existem, no uso dos jogos, dois aspectos primordiais: um, refere-se à emoção e afetividade e se expressa durante a ação enquanto, o outro, refere-se a aspectos cognitivos, refletindo os avanços nos processos de desenvolvimento da aprendizagem proporcionados pelo jogo. Nesse momento, é de fundamental importância enfatizar esse último aspecto, que envolve o lado cognitivo do jogo, pois serão explicitadas, a seguir, as idéias de pesquisadores embasadas nas perspectivas de Vygotsky.

O brinquedo é considerado, por Vygotsky (2007), uma importante fonte de promoção de desenvolvimento. Apesar do brinquedo não ser 0 aspecto predominante da infância, ele exerce uma enorme influência no desenvolvimento infantil. 
Para Leontiev (1978) e Elkonin (1998), ambos apoiados nos estudos realizados por Vygotsky (1998; 2000; 2005; 2007), a brincadeira é objetiva, pois é uma atividade social na qual o sujeito se apropria do mundo real dos objetos e dos seres humanos da maneira que lhe é possível, nesse estágio do desenvolvimento. Tais estudiosos entendem que o componente indispensável à brincadeira é a fantasia, a imaginação, não sendo sua função criar, para a criança, um mundo diferente do mundo dos adultos, mas possibilitando a ela a apropriação do mundo que a cerca, a despeito da sua impossibilidade de desempenhar as mesmas tarefas que são realizadas pelos adultos.

Nas pesquisas de Vygotsky (2005; 2007) aparece, constantemente, essa idéia de reconstrução, de apropriação do mundo ou até de reelaboração, por parte de indivíduo, dos significados que lhe são transmitidos, principalmente em relação ao grupo cultural e ao meio em que eles estão envoltos, ocorrendo, assim, uma evolução no seu desenvolvimento. Ou seja, o aspecto afetivo vai ser fator influenciador do lado cognitivo. Acreditamos que a conseqüência do envolvimento emocional do educando na ação é a facilitação de seu desenvolvimento no aspecto cognitivo.

A evolução do jogo está intimamente relacionada com o desenvolvimento da criança de acordo com os aspectos abordados nos relatos de Elkonin (1998). Em outras palavras, é no jogo que a criança deve ser competente para manipular e atuar com os objetos envolvidos no processo. O principal significado do jogo, para Elkonin (1998), é permitir que a criança modele as relações entre as pessoas e entre elas e os objetos. O jogo é influenciado pelas atividades humanas e pelas relações entre as pessoas e o conteúdo, suas atividades e as relações com os adultos. Ao mesmo tempo, ele exerce influência sobre o desenvolvimento psíquico da criança e sobre a formação dos conceitos e de sua personalidade.

Em relação aos jogos, os mesmos podem ser considerados como sendo meios indutores da produção de ambientes desafiadores, capazes de estimular a cognição, a imaginação e o intelecto, proporcionando a conquista de estágios mais elevados de raciocínio. Esses fatores são promovidos pela utilização de jogos em sala de aula, segundo apontam os estudos de Rego (2000). Essa situação vem a corroborar que o pensamento conceitual é uma conquista que depende não somente do 
esforço individual, mas, principalmente, do contexto em que o indivíduo se insere, influenciando, assim, nos seus limites cognitivos.

Nos estudos apresentados por Elkonin (1998) e Leontiev (1988), Facci (1980) afirma que, segundo esses autores, existem cinco distintos estágios de desenvolvimento, que são definidos por diferentes fases etárias. Cada estágio de desenvolvimento da criança é caracterizado por uma relação determinada por uma atividade essencial que desempenha a função de ser a principal forma de relacionamento do sujeito com a sua realidade.

Os dois primeiros estágios envolvem um público cuja faixa etária está fora do alcance da pesquisa, ou seja, idade pré- escolar, porém, os três últimos estágios serão sintetizados a seguir e encontram-se na fase escolar. Priorizaremos, ainda, o último estágio, pois envolve a adolescência. Um desses estágios, que ocorre na idade escolar, é composto pelo "jogo/brincadeira" como atividade principal, em que se utilizam recursos por meio dos quais o educando se apossa do mundo concreto dos objetos humanos, através da reprodução das ações realizadas pelos adultos. Deve-se lembrar que as brincadeiras não são instintivas e o que determina seu conteúdo é a percepção que a criança tem do mundo dos objetos operados pelo homem.

De acordo com Leontiev (1988), nessa etapa da vida, o mundo ao redor da criança se decompõe em dois grupos. Um primeiro grupo (primário) consiste em pessoas inteiramente relacionadas com ela, de modo que as relações com essas pessoas determinam suas relações com todo o resto do mundo, ou seja, nesse caso, o fator que define esse grupo é o emocional. As pessoas que têm mais contato com a criança e com os educandos, como familiares, amigos, colegas de escola e, também, o professor fazem parte desse grupo primário. Por sua vez, um segundo círculo (secundário), mais amplo, é formado por todas as demais pessoas, sendo que, nesse caso, as relações são mediadas pelas relações que a criança estabeleceu no primeiro círculo, mais estreito.

É de fundamental importância a qualidade do relacionamento entre esses grupos e, também, entre os sujeitos presentes em uma sala de aula e o seu professor. Todos têm conhecimento da importância do aspecto qualitativo da atenção dispensada aos alunos, por seus professores. Nesse estágio de suas vidas, de acordo com Leontiev (1988), os alunos, freqüentemente, recorrem à sua mediação 
em suas relações com outras crianças de sua idade. Pode-se dizer que as relações com o professor fazem parte do pequeno e íntimo círculo dos contatos dos educandos.

O desenvolvimento individual se dá, segundo Rego (2000), em um ambiente social determinado e a relação com o outro, nas diversas esferas e níveis de atividade humana, é essencial para o processo de construção do ser psicológico individual.

As relações da criança dentro de um grupo de iguais são também peculiares. Nesse aspecto, o professor desempenha o papel principal, papel de mediador, de pacificador, orientador, mais uma vez, em virtude de suas relações pessoais com as crianças, pois existem tarefas que uma criança não é capaz de realizar sozinha, mas que se torna capaz de realizar se alguém the der instruções, fizer uma demonstração, fornecer pistas, ou der assistência durante o processo.

Com o passar do tempo, as crianças alcançarão novas fases etárias e conseqüentemente os objetivos e ideais serão alterados. Nesse caso, o que vai sofrer uma mudança significativa é atividade principal, porém, Lima (2005) destaca que a mudança na atividade principal não elimina a importância da atividade lúdica no desenvolvimento da criança, pois a entrada no período escolar coincide com a evolução de sua maneira de jogar. Nessa situação, a brincadeira, que na fase precedente ocupava o lugar de atividade principal, cede lugar ao jogo.

Nessa etapa da vida intermediária, entre a infância e adolescência, o estudo se apresenta como o elo que inter-relaciona a criança com os adultos que a cercam, incluindo a comunicação pessoal e social. Nesse processo, todo o sistema de relações da criança é reorganizado. Para Leontiev (1988), o cerne dessa questão reside no fato de que, agora, não existem deveres apenas para com os pais e os professores, mas há, e de modo objetivo, obrigações para com a sociedade. Nessa perspectiva, as atividades devem introduzir o aluno nas tarefas escolares, de forma que ele se aproprie dos conhecimentos científicos. Fundamentada em Davidov (1988), Facci (1980) nos chama a atenção para o fato de que, nesse período do desenvolvimento da criança, surgem a consciência e o pensamento teórico e desenvolvem-se nela, entre outras funções, as capacidades de reflexão, análise e planificação mental. 
Uma nova transição ocorre com a chegada da adolescência. Essa fase do desenvolvimento é de fundamental importância para o nosso estudo, pois os grupos de alunos investigados, do final do ciclo do Ensino Fundamental II (9ำ ano), estão começando a entrar nessa etapa. Ocorre, nessa fase, a mudança da atividade principal, surgindo uma interação entre colegas presentes em mesmos grupos ou turmas. Nesse momento do desenvolvimento, tem início uma mudança na posição que o jovem ocupa com relação ao adulto, ou seja, as suas forças físicas, juntamente com os seus conhecimentos e capacidades, colocam-no, em certos casos, próximos psicologicamente, cognitivamente e fisicamente dos adultos e, em muitas situações, em alguns aspectos particulares, até em posição superior.

Segundo Vygotsky (2005), nessa fase de desenvolvimento se produz no adolescente um importante avanço no desenvolvimento intelectual, formando-se verdadeiros conceitos. Por esse motivo, foi escolhida a faixa etária a ser investigada nessa pesquisa. $O$ pensamento por conceitos amplia para o adolescente o mundo da consciência social, e o conhecimento da ciência, da arte e das diversas esferas da vida cultural pode ser corretamente assimilado, o que não seria possível de acontecer nas fases anteriores. Por meio do pensamento por conceitos, de acordo com Facci (1980), o adolescente chega a compreender a realidade, as pessoas ao seu redor e a si mesmo. O pensamento abstrato desenvolve-se cada vez mais e o pensamento concreto começa a pertencer ao passado. $O$ desenvolvimento do pensamento abstrato facilita o entendimento dos fenômenos, especificamente em relação às ciências naturais. O conteúdo do pensamento do jovem converte-se em convicção interna, em orientações dos seus interesses, em normas de conduta, em sentido ético, em seus desejos e seus propósitos.

De acordo com os relatos de Elkonin (1998), a adolescência é um dos períodos de desenvolvimento do ser humano mais confuso e crítico, os adolescentes vivem em constantes conflitos. Nesse período, essa atividade especial é uma forma de reproduzir com os companheiros as relações existentes entre as pessoas adultas, através do estabelecimento de relações pessoais íntimas entre os adolescentes. Nesse entendimento, a interação com os companheiros é mediada por determinadas normas morais e éticas (regras de grupo). Todavia, a atividade de estudo continua sendo considerada importante para os jovens e ocorre, por parte deles, o domínio da estrutura geral dessa atividade, a formação de seu caráter, a tomada de consciência 
das particularidades individuais de trabalho e a utilização dessa atividade como meio para organizar as interações sociais com os companheiros de estudo (colegas e professores).

Nos estudos apresentados por Facci (1980), esse comportamento em grupo dá origem a novas tarefas e motivos que instigam atividades dirigidas. $O$ objetivo de se trabalhar em grupo é o de facilitar a aprendizagem e a relação entre alunos e professores.

Esse aspecto é o fundamento da proposta metodológica de ensino investigada nesta Dissertação, devido à importância desse enfoque, nessa fase do desenvolvimento do adolescente. Nesse instante, através de uma atividade cognoscitiva e investigativa criadora, o domínio dos meios de atividade de estudo autônomo pode auxiliar no processo de ensino e aprendizagem, especificamente, em ciências.

\section{3- A brincadeira E O Jogo na PERSPECtiva Histórico- CULtURAL}

As brincadeiras e os jogos apresentam-se de formas distintas, principalmente quando relacionadas à concepção de Vygotsky (2007). Consideramos o jogo e a brincadeira como recursos pedagógicos que representam um contexto estimulante e propício para a aquisição de conhecimentos, habilidades e atitudes, salientando-se a importância que ocupa a linguagem como um instrumento sócio-cultural de mediação, no processo de socialização das crianças.

A brincadeira, segundo Vygotsky (2007), é a atividade principal, porque cria uma zona de desenvolvimento proximal na criança (ZDP), ou seja, através do brinquedo a criança irá realizar ações que estão além de seu desenvolvimento, buscando apreendê-lo. A zona de desenvolvimento proximal, segundo Rego (2000), refere-se ao caminho que o indivíduo irá percorrer para desenvolver funções que estão em processo de amadurecimento e que se tornarão funções consolidadas, estabelecidas em seu nível de desenvolvimento real. A ZDP é um domínio psicológico em constante mudança, pois aquilo que uma criança é incapaz de realizar sozinha, ela conseguirá fazer posteriormente, de forma autônoma. 
A criança utiliza a imaginação na brincadeira como uma forma de realizar operações que lhe são impossíveis, em razão da limitação de suas habilidades, provocando, assim, revoluções que promovem o desenvolvimento infantil para patamares progressivamente mais evoluídos.

É enfatizado ainda, por Vygotsky (2007), que o brinquedo é muito mais a lembrança de alguma coisa que realmente ocorreu do que imaginação. É mais a memória em ação do que uma situação imaginária nova. Leontiev (1988) ressalta que, na brincadeira, todas as operações e ações que a criança realiza são reais e sociais; por meio delas, a criança busca apreender a realidade criando uma ruptura entre sentido e significado de um objeto, mas, durante a brincadeira, esse objeto pode assumir sentidos distintos.

Já em relação à concepção de jogo, de acordo com os apontamentos de Oliveira (1999), não é apenas o brinquedo ou brincadeira que irá criar uma zona de desenvolvimento proximal no aluno. O jogo cria uma situação de regras que irá proporcionar também uma ZDP, fazendo com que o aluno comporte-se de forma mais avançada do que nas atividades da vida real e também aprenda a separar objeto e significado.

Torna-se necessária a diferenciação dos tipos de jogos existentes, Jogos de Papéis, Jogos Protagonizados e Jogos de Regras. Porém, nesta Dissertação, iremos descrever apenas o jogo de papéis e os jogos de regras. O jogo de papéis é desenvolvido de forma mais intensa e alcança seu nível máximo de desenvolvimento no período pré-escolar, quando a criança deixa a fase da atividade de manipulação dos objetos. É importante frisar que, segundo Elkonin (1998), existe sim necessidade de exposição da criança às mais ricas situações e produções humanas, pois, quanto maior e mais fértil for a sua inserção no mundo que a circunda, mais fácil será a contemplação da imaginação em suas atividades lúdicas e mais facilmente a criança desenvolverá suas habilidades.

Os estudos de Elkonin (1998) apresentam que a base do jogo é socialmente construída devido a sua natureza e sua origem, ou seja, o jogo nasce das condições de vida da criança em sociedade. Na perspectiva da Teoria Histórico-Cultural, a evolução do jogo de papéis culmina no jogo de regras. De acordo com Leontiev (1988), os jogos de regras surgem a partir dos jogos de papéis com situação imaginária. 
O jogo de regras e jogos de papéis apresentam-se de formas opostas. Enquanto o jogo de papéis caracteriza-se por regras implícitas e a imaginação explícita, no jogo de regras ocorre uma inversão desses componentes, ou seja, nesse nível de jogo, a imaginação é implícita e as regras são explícitas. O nascimento desse nível de jogo converge, quase sempre, com o período em que a criança ingressa no Ensino Fundamental. Se, na Educação Infantil, o jogo é visto e entendido como um recurso útil ao desenvolvimento e aprendizagem da criança, no Ensino Fundamental, ao contrário, na maioria das instituições de ensino, ele ocupa uma posição dicotômica em relação ao estudo.

Para a Teoria Histórico-Cultural, o jogo como elemento e produto da cultura, que depende da aprendizagem, possui três características básicas: a regra, a imitação e a imaginação. Em se tratando da idade escolar (idade que interessa à presente pesquisa), Vygotsky (2007) postula que as regras se tornam explícitas, de modo a predominarem sobre a imaginação.

Além da preponderância das regras, nessa faixa escolar, Vygotsky (2007) frisa a importância de outra característica definidora do jogo: a imitação. No entanto, não se pode considerar o jogo, de forma alguma, como mera reprodução do real, pois o aluno irá se basear em algo já instituído, proveniente de distintas experiências. Logo, a imitação que o jogo propicia deve ser vista como a reconstrução individual daquilo que a criança aprendeu com os outros, fato este que remete à internalização.

O jogo se configura como um terreno fértil à concepção mediadora de ensino. De acordo com Vygotsky (2007), a aprendizagem é produzida pelas interações sociais, destacando-se o papel da mediação social, que será explicitado logo a seguir e, também, no item 5.4, para o desenvolvimento das funções tipicamente humanas (emoção, imaginação, percepção, memória voluntária, atenção, criatividade, abstração, generalização, pensamento e linguagem). Essas funções são mais conhecidas como Funções Psicológicas Superiores (FPS). Conforme aponta Rego (2000), tais processos mentais consistem no modo de funcionamento psicológico e são considerados sofisticados e superiores porque se referem a mecanismos intencionais, ações controladas conscientes e processos voluntários, que dão ao indivíduo a possibilidade de independência em relação às características do momento e espaço presente. 
O fato de as FPS serem elaboradas na relação que o indivíduo estabelece com o mundo e com os outros, via mediação, não faz com que as funções psicológicas elementares (FPE), desapareçam: a repetição, percepção, memorização e as funções básicas biológicas e motoras não deixam de existir com a emergência do social; ao contrário, as FPE são incorporadas pelas FPS e passam a ter uma nova configuração.

A passagem das funções psicológicas elementares para as superiores ocorre pela mediação proporcionada pela fala, que, no processo de humanização da criança, cumpre a função de ser o principal instrumento. Na vertente de Vygotsky (1999), a fala ocupa uma posição de destaque no processo de humanização da criança, ou seja, essa forma de comunicação intervém de modo significativo em seu desenvolvimento, desde seu nascimento. A criança não se apropria qualitativa e quantitativamente dos conhecimentos desejáveis, mas o faz por meio de interações com os integrantes mais experientes de seu grupo social, ou seja, é na relação com o outro, nas experiências de aprendizagem que o desenvolvimento se processa.

O jogo favorece a interação, ou o compartilhamento de ações pelas crianças, ao mesmo tempo em que regula e delimita as possibilidades dessas ações. Para poder jogar, a criança precisa compreender as regras que organizam, estruturam e sistematizam o desenvolvimento do jogo, rumo ao encontro de uma determinada natureza e, também, da aprendizagem de novos conceitos e procedimentos, exigindo distintas habilidades como o raciocínio antecipatório da criança na análise e interpretação de jogadas e atitudes realizadas pelo adversário, bem como o planejamento de suas próprias. Para isso, várias FPS são mobilizadas: atenção e memória ativas, raciocínio lógico, levantamento de hipóteses, avaliação das jogadas realizadas para resolver o problema propostos pelo jogo, escolha decorrente da avaliação feita, bem como linguagem, formação de conceitos e pensamento abstrato.

A mediação, caracterizada por Vygotsky (2007) como a relação do homem com o mundo e com outros homens, é de fundamental importância, justamente porque é através desse processo que as funções psicológicas superiores, especificamente humanas, se desenvolvem. $O$ entendimento de tal elemento mediador na relação organismo-meio significa que a relação mais importante do homem com o mundo não é a relação direta, mas a relação mediada. E são as funções psicológicas 
superiores que organizam essa relação entre o homem e o mundo real, por meio dos mediadores chamados instrumentos e signos.

Elkonin (1998) discute a respeito do jogo de regras e de como ele não se torna um instrumento importante para o processo de ensino-aprendizagem por si mesmo, porque, como no jogo de papéis, o fundamental não é o objeto, porém as relações entre as pessoas, na medida em que interagem com tais objetos. Entende-se, portanto, que não é a relação homem-objeto que é primordial. É, antes, a relação homem-homem, bem como a mediação que o jogo propicia, no decorrer das interações sociais, que levam à aprendizagem e, por conseqüência, ao desenvolvimento. Na verdade, o que vai promover uma boa aprendizagem, segundo Campos (2004), não é o jogo por si só, mas, o clima de discussão e troca que o professor propicia, permitindo tentativas e incentivando as respostas divergentes ou alternativas, tolerando os erros, promovendo sua análise e não simplesmente corrigindo-os ou avaliando o produto final.

Nesta pesquisa, o jogo se apresenta como principal instrumento de mediação. Através das inter-relações apresentadas, desenvolvemos a análise dos processos de socialização dos alunos investigados.

\section{4- A Mediação e Desenvolvimento das Funções Psicológicas Superiores (FPS)}

Vygotsky $(2005,2007)$ dedicou-se ao estudo das funções psicológicas superiores, funções mentais mais complexas, típicas do ser humano, que envolvem o controle consciente do comportamento como a emoção, imaginação, atenção, percepção, memória, generalização, abstração (construção de representações mentais), criatividade, pensamento, linguagem e a capacidade de planejamento, que incluem mecanismos interativos, com possibilidade de manter certa independência diante das características e pressões do momento, do tempo e espaço presentes. Trata-se de funções que se originam nas relações entre indivíduos humanos e desenvolvemse ao longo do processo de internalização de formas culturais de comportamento.

Essas FPS conforme apontamentos de Vygotsky (2007) originam-se nas relações entre o indivíduo e seu contexto sócio-cultural. Isto é, o desenvolvimento humano 
não é dado a princípio, não é imutável, não há passividade, nem independência do desenvolvimento histórico e das formas sociais da vida humana. Instrumentos culturais serão fatores influenciadores da internalização das informações. As FPS serão desenvolvidas através da mediação do professor e dos recursos lúdicos utilizados nessa atividade. Para maior entendimento desse processo, torna-se necessário definir, a priori, o termo mediação.

A mediação, segundo Vygotsky (2005), é um processo de intervenção de um elemento intermediário numa relação, ou seja, a relação deixa de ser direta e passa a ser mediada por esse elemento. A mediação se caracteriza como a relação de homem com o mundo e com outros homens, sendo desenvolvida através das FPS.

Ratner (1995), fundamentado em Vygotsky, distingue três espécies de mediação. A primeira é a consciência (ou atividade mental), a segunda é a cooperação social (sociabilidade) e, a última, é relacionada aos instrumentos (tecnologia).

A atividade mental representada pela consciência é uma percepção relativamente abrangente das coisas e processa ativamente a informação. A sociabilidade, simbolizada pela cooperação social, é a atividade conjunta coordenada com outros indivíduos. A tecnologia, terceiro tipo de mediação entre o organismo e o mundo, está presente nos instrumentos e relaciona-se intimamente com as outras duas: a consciência e a sociabilidade. Como elas, os instrumentos são construtos artificiais que transcendem nosso organismo físico e aumentam suas capacidades mediadoras.

Os três tipos de mediação, consciência, sociabilidade e tecnologia, são interdependentes, reforçando-se mutuamente e determinando o impacto que os estímulos internos e externos exercem sobre o organismo. Cada um é, simultaneamente, causa e efeito. Todos se desenvolvem por meio de interações. A base dessa relação é que a consciência se forma nas relações sociais e na tecnologia. Esse processo modela a forma, o conteúdo e o nível de desenvolvimento da consciência. Portanto, para Ratner (1995), a consciência é um fenômeno social que só se desenvolve mediante a participação na atividade social prática.

Deste modo, a interpretação e organização desses estímulos, derivados socialmente, determinam as funções psicológicas superiores fornecendo, 
reciprocamente, informações que modificam os esquemas cognitivos, causando alterações no mundo físico e social.

Para Vygotsky (2000), além dos três tipos de mediação apresentados para complementar existem os instrumentos ou ferramentas mediadoras que são elementos externos ao indivíduo, voltados para fora dele, cuja função é a de provocar mudanças nos objetos e, conseqüentemente, controlar os processos da Natureza. Existem dois instrumentos ou elementos que são fundamentais para a mediação: o instrumento e o signo. O primeiro possui função reguladora, principalmente entre as ações sobre os objetos e, o segundo, que também possui uma função reguladora, é um instrumento psicológico, orientado para o próprio indivíduo, e tem a função de auxiliar o homem em suas atividades psíquicas, em tarefas que exigem, principalmente, memória e atenção. Embora diferentes, estão mutuamente ligados pela função mediadora ao longo da evolução da espécie humana e do desenvolvimento de cada indivíduo.

\section{5- Desenvolvimento das FPS através da mediação realizada pelo processo do Jogo.}

A ação realizada durante o movimento do jogo provoca espontaneidade, induzindo à formação de estímulos suficientes para que o aluno transcenda a si mesmo. Essa experiência integrada favorecerá o surgimento de um novo aluno, um aluno ativo e participativo dentro de um ambiente total. $\mathrm{O}$ aluno assimila características e atitudes antes desconhecidas pelos colegas, pelo professor e, principalmente, para ele mesmo, permitindo assim o desenvolvimento de qualquer habilidade que o professor entenda como necessária para a comunicação e desempenho dentro da sala de aula, durante e após o uso do jogo.

Nesta perspectiva, o jogo é fundamental para que os processos de desenvolvimento se efetivem, resultando em grandes avanços e melhoras nos processos de aprendizagem e, conseqüentemente, no seu desenvolvimento. A utilização de jogos como recursos metodológicos pode atuar no preenchimento das lacunas de aprendizagem deixadas por outras metodologias empregadas em sala de aula. 
A seguir (5.5.1 a 5.5.8.), iremos explicitar cada uma das Funções Psicológicas Superiores a serem identificadas nas análises de dados dessa pesquisa.

\subsection{1-EMOÇÃO}

A emoção é uma função presente em todos os seres humanos, permeando qualquer forma do pensamento, ou comportamento, e deve ser entendida, de acordo com Vygotsky (2005), como uma reação nos momentos críticos do comportamento, tanto os de desequilíbrio, como aqueles de síntese e resultado do comportamento. Essa função influi a cada instante e de forma imediata nas formas de comportamento posteriores.

\subsection{2- IMAGINAÇÃO}

A emoção, assim como a imaginação, organiza as formas de comportamento do ser humano. A imaginação também pode ser considerada, segundo Vygotsky (2005), como reguladora do comportamento.

Podemos constatar que a capacidade imaginativa e a atividade lúdica decorrem das condições concretas da vida do educando. De acordo com os estudos de Rocha (2000), o processo imaginativo não faz parte das atividades naturais dos alunos dessa faixa etária. Nesse caso, torna-se imprescindível a criação de estímulos no processo de mediação. Na visão dos teóricos da vertente histórico-cultural, fazer o aluno penetrar no domínio do imaginário e capacitá-la dentro dele, significa tornarIhe acessível uma multiplicidade de experiências que contribuem, de maneira fundamental, para transformações cognitivas e psíquicas.

\subsection{3- PeRCEPÇÃo}

A terceira função a ser desenvolvida é a percepção. Podemos considerá-la como um caso particular da imaginação, pois a mesma, de acordo com Vygotsky (2000), é uma imagem figurada da realidade, criada pela mente, que toma a impressão 
exterior como ponto de apoio e que deve sua origem à atividade criativa da própria cognição.

Para Vygotsky (1998), a maior parte de nossas percepções conscientes provém do meio externo. Basicamente, é a apreensão de uma situação objetiva, fundamentada em representações.

\subsection{4- MEMÓRIA}

Vygotsky (1999) realizou, ainda, um estudo sistematizado das formas superiores de memória (capacidade de conservação e reprodução de informações) na criança, distinguindo, assim, três tipos distintos de memória. São elas: memória natural, memória não mediada e memória mediada por signos.

A memória natural, classificada como FPE (Função Psicológica Elementar), caracteriza-se por ser involuntária e ter uma base biológica, possuindo, assim, uma relação direta e imediata com os estímulos externos. As informações armazenadas são muito próximas às detectadas pelos órgãos dos sentidos. Essa memória, de acordo com Vygotsky (1999), resulta de uma ação direta das impressões externas das pessoas e é tão direta quanto a percepção imediata. Do ponto de vista estrutural, a característica mais importante de todo esse processo é o imediatismo.

A memória não mediada está presente nas determinações inatas do organismo humano e é ligada diretamente aos estímulos externos recebidos. Já a memória mediada se refere a um tipo de registro que inclui ação voluntária, fazendo com que o indivíduo se apóie em elementos mediadores que o ajudem a lembrar-se de conteúdos específicos. Esses elementos mediadores podem ser calendários, agendas, cadernos, diários, lista de compras, dentre outros.

A pesquisa descrita nesta Dissertação considera os jogos, utilizados nas etapas metodológicas, como o elemento de mediação que irá influenciar diretamente na FPS. Essa atividade pode contribuir significativamente para o incremento da capacidade de memorização e da forma de relação com conteúdos culturais e, portanto, com processos de aprendizagem.

Segundo Vygotsky (1999), quando se estuda a memorização mediada, ou seja, quando o ser humano memoriza apoiando-se em determinados signos ou 
procedimentos, vê-se que o lugar da memória no sistema das funções psíquicas muda, passando de elementar para superior. A memória deixa de ser uma estrutura imediata, transformando-se em função mediata, por relação entre o estímulo e a ação. A forma superior supera, por incorporação, a elementar.

Para Vygotsky (2005), do ponto de vista da evolução psíquica, não é o pensamento abstrato que está presente no começo do desenvolvimento, mas sim a memória, que constitui seu momento determinante. No entanto, no final do desenvolvimento infantil, as relações interfuncionais da memória variam radicalmente em sentido oposto: se, para a criança, pensar é recordar, para o adolescente recordar é pensar. Sua memória está tão ligada à lógica que memorizar se reduz a estabelecer e encontrar relações lógicas e recordar consiste em buscar uma seqüência lógica fundamentada, de acordo com Vygotsky (2005), em uma complicada fusão do pensamento e da memória.

À medida que a criança cresce não somente muda as atividades evocatórias da memória, como também seu papel no sistema das funções psicológicas. $O$ indivíduo começa a sistematizar seu conhecimento, através da internalização das FPS, desenvolvendo, assim, a memória mediada que está sendo organizada por conceitos, baseando-se no pensamento abstrato.

\subsection{5- Pensamento e linguagem}

Vygotsky (2005), no livro Pensamento e Linguagem, prioriza essas duas FPS, destacando a importância do estudo da relação entre pensamento e linguagem para se compreenderem as relações entre as diferentes funções psicológicas.

A linguagem (verbal, gestual e escrita) é instrumento de relação com os outros e, por isso, é importantíssima na constituição dos alunos como sujeitos. Além disso, é através da linguagem que se aprende a pensar (Ribeiro, 2005). Pensar é conceber, fragmentar e seqüenciar - ao mesmo tempo - uma dada situação. As palavras são mediadores entre o pensamento e mundo externo.

De acordo com Carvalho (2003), a linguagem seria o principal instrumento no processo de internalização, cuja função mediadora reside na possibilidade da significação, que, em razão de sua natureza, acontece no próprio momento da 
comunicação. Segundo Vygotsky (2005), a linguagem é o sistema simbólico básico de todos os grupos humanos, tendo papel fundamental na comunicação entre os seres humanos, pois, por meio de significados partilhados, podem-se interpretar objetos, eventos e situações.

O grupo social ao qual o indivíduo pertence estabelece as formas de perceber e organizar o real, as quais acabarão por constituir os instrumentos psicológicos que fazem a mediação entre este indivíduo e o mundo. Os grupos estudados na presente pesquisa são compostos por adolescentes que possuem comportamento, formas de pensar e agir e linguagem próprias, na maior parte do tempo incrustada de gírias, expressões características e atitudes específicas, facilitando, assim, a compreensão entre eles. Essas características de ação e pensamento personificam a linguagem destes grupos.

\subsection{6- ATENÇÃO}

Outra função psicológica estudada por Vygotsky (2005) é a atenção, uma vez que o homem seleciona, dentre os inúmeros estímulos recebidos, os mais importantes. $O$ objetivo é facilitar o processo racional do pensamento. A definição dada por Luria (1991), tomando como base o processo seletivo, é que "a seleção da informação necessária, o assessoramento dos programas seletivos de ação e a manutenção de um controle permanente sobre elas são convencionalmente chamados de atenção". Se não houvesse seleção das informações e inibição de grande parte das associações, seria impossível o pensamento organizado, as atividades e, conseqüentemente, as soluções dos problemas. Em todas as atividades humanas, as seleções dos processos básicos dominantes constituem o objetivo da atenção.

\subsection{7- GeneralizaçÃo E AbstraçÃo}

Uma palavra não se refere apenas a um objeto, mas a uma classe de objetos, portanto, Vygotsky (2005) explicita que cada palavra já é uma generalização. A mesma é um ato verbal do pensamento e reflete a realidade de modo bem distinto. 
O significado também é um ato de pensamento e, ao mesmo tempo, é parte inalienável da palavra, pertencendo, assim, aos domínios da linguagem e do pensamento.

Não existe palavra sem significado e não há significado sem linguagem, pois o significado é conceito a ser apreendido. Segundo Vygotsky (2005), evoluem a partir do desenvolvimento cognitivo do aluno, dependendo, dessa forma, do grau de generalização presente.

A formação de conceitos, como apresentado nos estudos de Vygotsky (2005), possui duas vertentes. São elas: a raiz dos complexos e a raiz dos conceitos potenciais. A primeira envolve o desenvolvimento da generalização e da síntese, em que cada função estabelece relações; a segunda permite o desenvolvimento da abstração e da análise, que se expressam na capacidade de examinar elementos separadamente da totalidade da experiência concreta.

\subsection{8- CRIATIVIDADE}

No jogo, o indivíduo pode explorar sua criatividade através do processo envolvido na atividade e conseqüentemente irá testar hipóteses de forma natural. O jogo, nesse contexto, será essencial para que o educando manifeste sua criatividade, utilizando suas potencialidades de maneira integral.

A criatividade passa a ser vista como um fenômeno universal e social que só pode ser compreendido de forma contextualizada, considerando a inserção do sujeito em seu momento histórico, internalizado pelo sujeito a partir de suas experiências e contatos com a cultura. As condições econômicas, materiais, sociais e culturais irão influenciar de forma marcante o processo criativo.

Vygotsky (2000) explicita em seus relatos que a criatividade deve ser considerada uma regra e não uma exceção, sendo um fenômeno integrante dos alunos, diferenciando-se em alguns educandos, mas existente em todos. A criatividade necessita de condições sócio-econômicas e culturais adequadas para desenvolverse, implicando em uma instância coletiva onde se entende que qualquer obra ou produto não é resultado da ação de apenas um sujeito e sim conseqüência da ação 
e influência de todos integrantes dos grupos. A abordagem sócio-histórica enriquece o entendimento do fenômeno criativo quando o situa em sua dimensão de função psicológica superior, resultado da interação homem- homem, homem-meio e homem-cultura.

O processo de desenvolvimento da criatividade é determinado pelo contexto cultural ao qual pertence o sujeito agente do ato criativo. Sua expressão criativa individual reflete a influência do coletivo, é obra do grupo, da dimensão social, onde ele, como agente, apenas exteriorizou o desejo, necessidade ou pensamento oriundo e emergente da cultura.

A variação do ambiente dará as nuances do desenvolvimento e expressão da criatividade surgindo do domínio sócio histórico- cultural como produto da interação do sujeito com seu ambiente, impulsionado, neste percurso, pelo jogo e todo processo que o envolve facilitando assim o desenvolvimento da aprendizagem. 
Capítulo 6: METODOLOGIA 


\section{1- Metodologia de estudo}

Uma proposta que contribui para a mudança do ensino de química que ainda é um ensino tradicional e positivista é a utilização de jogos e atividades lúdicas. O uso dessas atividades no Ensino de Ciências ou de Química é recente tanto nacional como internacionalmente. Vários autores têm apresentado jogos e destacado sua eficiência para despertar o interesse dos alunos pela Química (SCHRECK \& LANG, 1985; UtCHINSON \& WiLleRTON, 1985; StENCEL E BARKOFF, 1993, Mellou, 1994 e 1995; BanKS, 1996, Russell, 1999; Crute, 2000; Helser, 1999; Elchler et al, 2000, 2005; Granath \& Russell, 2000; Deavor, 2001; CAsby, 2003 Soares et alii, 2003; DkeIDek, 2003; CASBy, 2003; Penoni et al., 2003; CunHA, 2004; Passos \& SANtana, 2004; SoARES, 2004, 2008 e 2009; SANTANA, 2005, 2006, 2008; SeIlPELt, 2006, Borges E Schwarz, 2005; Oliveira \& Soares, 2005; Santana \& Wartha, 2006; Moreira, 2006 ; Moreira\& ReZENDE, 2008; Santana \& ReZende, $2007,2008,2009,2010$, entre outros).

A maioria desses autores destaca os jogos como elementos motivadores e facilitadores do processo de ensino e aprendizagem de conceitos científicos. Destacam que o objetivo dos jogos ou das atividades lúdicas não se resume apenas a facilitar que o aluno memorize o assunto abordado, mas sim a induzilo ao raciocínio, à reflexão, ao pensamento e, conseqüentemente, à (re) construção do seu conhecimento (Melo, 2005).

As atividades lúdicas, além de oferecerem o estímulo e o ambiente propícios para o favorecimento do desenvolvimento espontâneo e criativo dos alunos, segundo os estudos de Murcia (2005) permitem ao professor ampliar seu conhecimento de técnicas ativas de ensino. Assim, favorecem 0 desenvolvimento das capacidades pessoais e profissionais dos professores para estimular nos alunos a capacidade de comunicação e expressão, mostrando-lhes uma nova maneira, lúdica, prazerosa e participativa, de relacionar-se com o conteúdo escolar. Esse conjunto de fatores leva a apropriação dos conhecimentos envolvidos pelos alunos. 
Utilizar atividades lúdicas como instrumento pedagógico não se restringe a trabalhar com atividades prontas, mas, principalmente, a estimular a criação, pelos alunos, de atividades e jogos relacionados aos temas discutidos no contexto da sala de aula (Brasil, 1999).

Realizou-se um estudo bibliográfico sobre o uso de jogos no ensino de ciências nos últimos 80 anos, desde 1929 até o ano de 2009. Os motivos que levaram à escolha desse intervalo de tempo serão explicitados posteriormente. Foram selecionados os periódicos digitais e impressos que serão usados nesta análise e assim, tornou-se possível categorizar os jogos de acordo com três critérios iniciais e básicos. (Figura 6.1)

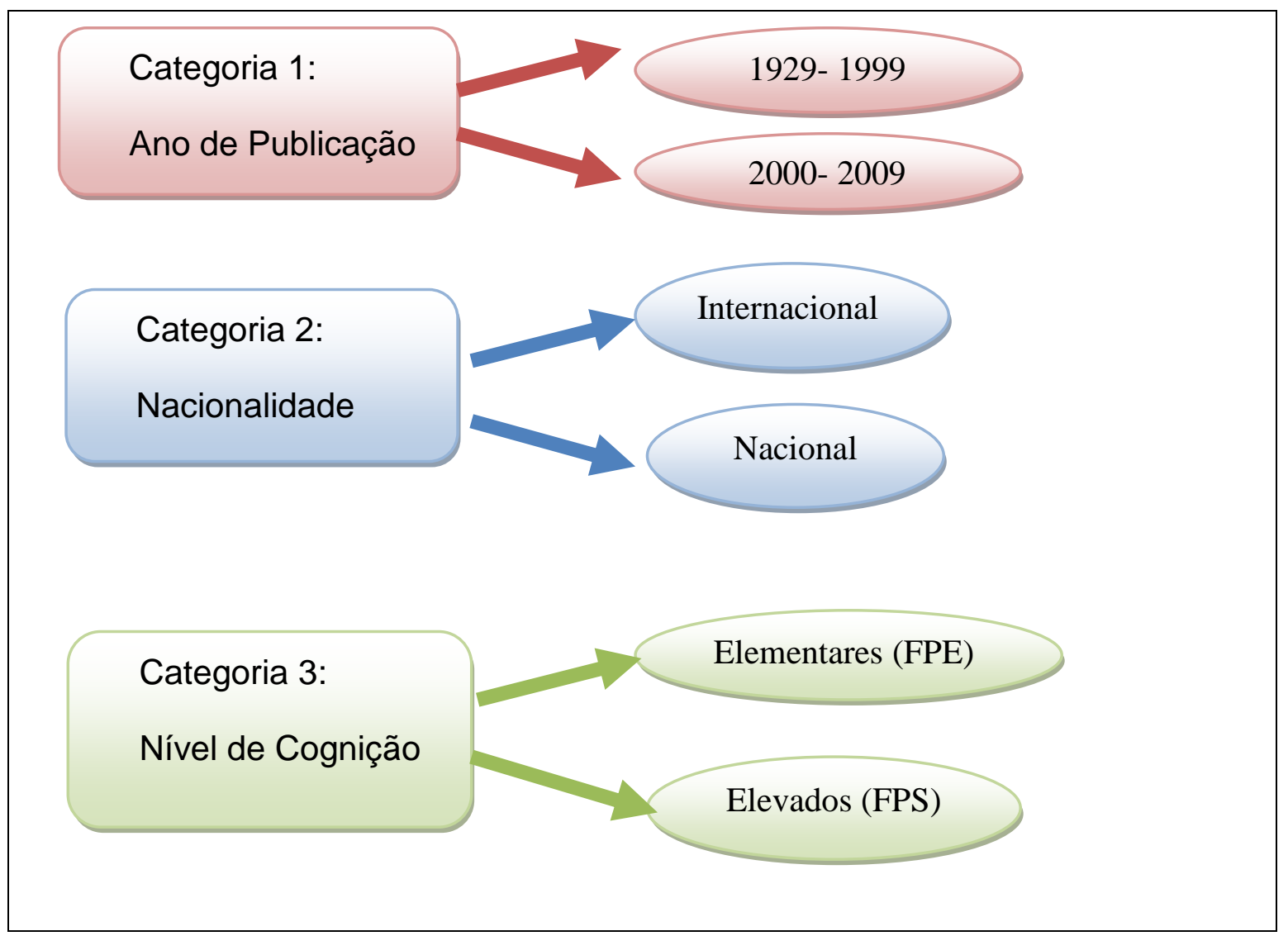

Figura 6.1: Fluxograma com categorias e subcategorias dos jogos.

Os periódicos pesquisados nesse estudo foram:

1- Periódicos Internacionais :

Journal of Chemical Education;

The Chemical Educator; 
Enseñanza de las ciências;

2- Periódicos Nacionais;

\begin{tabular}{l}
\hline Revista Química Nova; \\
\hline Revista Química Nova na escola \\
Revista Brasileira de Ensino de Química.
\end{tabular}

3- Anais de Congressos Nacionais.

\section{RASBQ (Reunião Anual da Sociedade Brasileira de Química) \\ ENEQ (Encontro Nacional de Ensino de Química) \\ ENPEC (Encontro Nacional de Pesquisa em Ensino de Ciências)}

4- Internet- sites de livre acesso à rede.

Este estudo apresenta uma análise a priori com essas três categorias, sendo analisados os periódicos citados anteriormente devido à acessibilidade dos mesmos para as pessoas que trabalham na área. Iremos nos concentrar nas categorias que serão explicitadas com mais detalhes no capítulo sete destinado aos resultados e discussões.

\section{2- Metodologia de Pesquisa}

\section{$\underline{\text { PÚBLICO-ALVO }}$}

O Autódromo Alquímico foi aplicado nos anos de 2006, 2007, 2008, 2009 e 2010 em uma escola privada localizada na cidade de Itabuna, no Estado da Bahia. O público-alvo deste estudo constitui-se de alunos do 9ํano do Ensino Fundamental, devido à vivência da pesquisadora nesse nível de ensino remontar ao ano de 2002. A atividade foi aplicada em nove turmas, totalizando 263 alunos, de classe-média e idade regular, cuja faixa etária varia de 13 a 15 
anos. Em três das nove turmas em que se aplicou o jogo foram realizados testes piloto enquanto, nas outras seis, foi feita efetivamente a coleta dos dados utilizados nesta pesquisa. As turmas foram identificadas de acordo com a Tabela 6.1.

Os testes pilotos foram feitos com o intuito de verificar a aplicabilidade da metodologia a ser trabalhada. À priori a análise diagnóstica inicial era realizada após a sensibilização por meio do filme Harry Potter e a Pedra Filosofal. Porém constatou-se que era necessário alterar a ordem dessa aplicação, pois os alunos ao responderem o pré-teste eram influenciados pelo filme. Logo resolveu-se alterar a ordem metodológica (figura 6.2) do processo total do jogo.

Tabela 6.1: Turmas em que foi aplicado o jogo.

\begin{tabular}{ccc}
\hline Turmas & Anos & Quantidade de Alunos \\
\hline A & 2006 & 39 \\
B & 2007 & 25 \\
C & 2007 & 30 \\
D & 2008 & 27 \\
E & 2008 & 28 \\
F & 2009 & 28 \\
G & 2009 & 27 \\
H & 2010 & 30 \\
I & 2010 & 28 \\
\hline
\end{tabular}

A Escola Pio XII, onde foi realizada a pesquisa é uma escola tradicional, com mais de 40 anos de funcionamento, localizada na cidade de Itabuna, no interior da Bahia. A escola apresenta uma boa infra-estrutura, possuindo aparelhos audiovisuais, um laboratório de informática, um auditório e recentemente foi inaugurado um laboratório de ciências naturais, facilitando assim o processo de ensino e aprendizagem. Na grade curricular da escola em que foi realizada a pesquisa e a coleta de dados, no nono ano já existe uma subdivisão da disciplina Ciências. Química, Física e Biologia são ensinadas separadamente em cargas horárias distintas, sendo que a primeira e a segunda (Química e Física) possuem quatro horas-aula (duas aulas teóricas e duas experimentais) 
e, a última (Biologia), três horas-aula. Além das aulas integrantes dos componentes curriculares esses alunos a partir do ano de 2009 começaram a ter aulas no laboratório de ciências no contraturno. Esses fatores foram fundamentais para a realização da pesquisa, pois assim tornou-se mais viável a aplicação do jogo e a coleta de dados.

\subsection{1- Etapas da Aplicação da Atividade LÚdicA}

\subsubsection{CARACTERIZAÇ̃̃O DA ATIVIDADE LÚDICA}

No caso do presente trabalho, o termo atividade lúdica não se refere apenas ao Autódromo Alquímico, mas ao conjunto do processo em sala de aula (Moraes e Rezende, 2009; Figura 6.2) que abrangeu 10 horas-aula, consistindo da aplicação do pré-teste, do uso de um filme, do estudo dirigido, de discussões, de pesquisas e do próprio autódromo, em que os alunos são os sujeitos ativos da ação, e o professor é o mediador da atividade envolvendo sete etapas como detalhado na Tabela 6.2. Já quando nos referirmos ao termo jogo estaremos relacionando ao tabuleiro “Autódromo Alquímico".

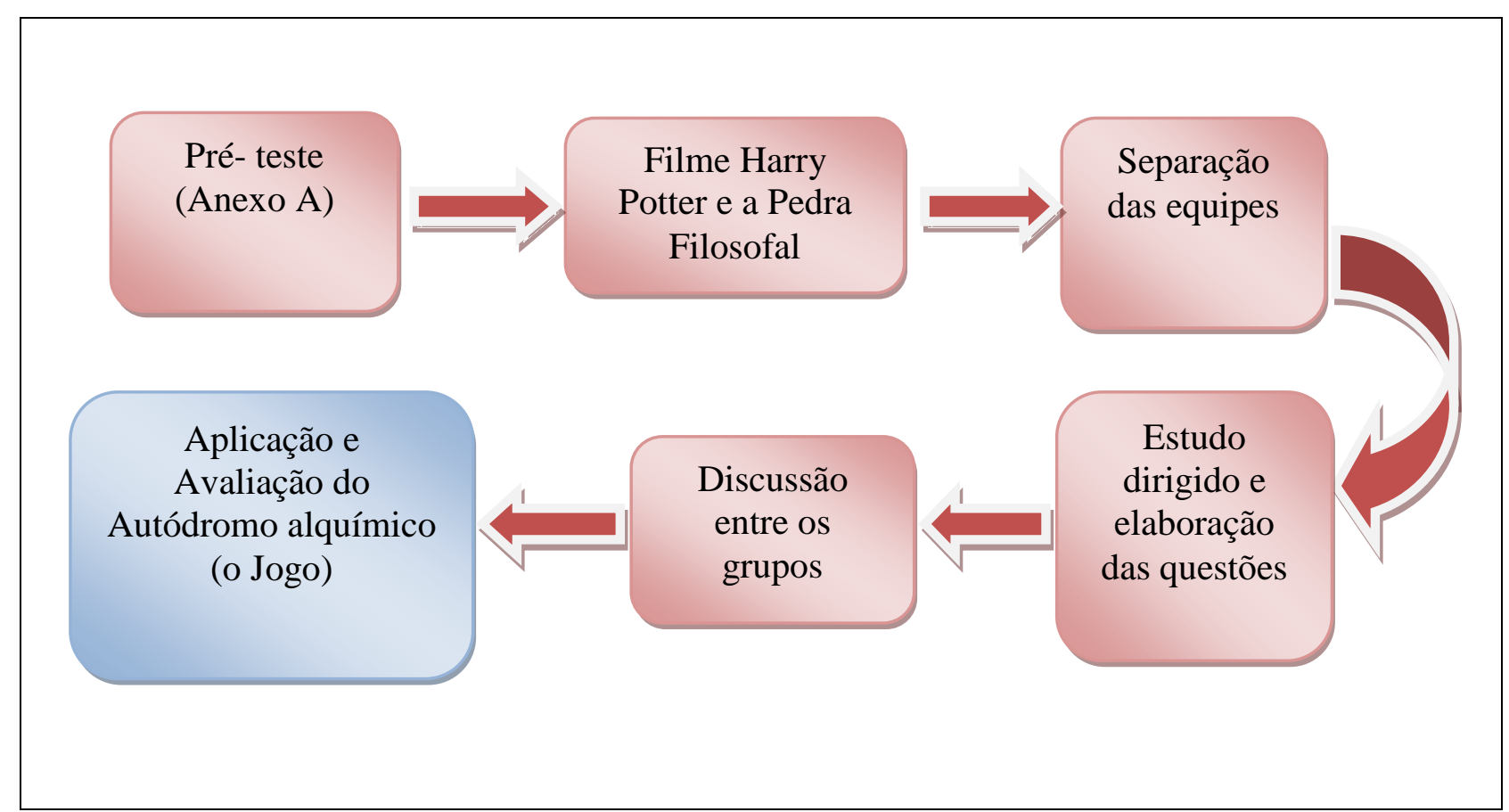

Figura 6.2: Etapas da aplicação da atividade lúdica. 
Tabela 6.2: Etapas da Metodologia da Atividade Lúdica

\begin{tabular}{cc|}
\hline Etapas da Metodologia & \multicolumn{2}{c}{ Horas-Aulas Necessárias } \\
\hline Sensibilização e Pré-teste & 1 \\
\hline Filme Harry Potter e a Pedra Filosofal & 2 \\
\hline Questionamentos sobre o filme & 1 \\
Estudo-dirigido sobre o tema & 2 \\
Elaboração de questões & 1 \\
Discussões sobre as questões e & 1 \\
dúvidas & 2 \\
\hline Autódromo Alquímico: O Jogo & \\
\hline
\end{tabular}

\subsubsection{2- PRÉ- TESTE (ANÁLISE DIAGNÓSTICA INICIAL) E SENSIBILIZAC̄̃̃O}

$\mathrm{Na}$ etapa inicial da aplicação do jogo, os alunos foram convidados a refletir e responder um pré-teste (análise diagnóstica inicial). Os professores recolheram o pré-teste (Anexo A) e convidaram os alunos a assistirem o filme Harry Potter e a Pedra Filosofal.

O filme Harry Potter e a Pedra Filosofal foi utilizado como instrumento sensibilizador introdutório às aulas de Química (Santana, Rezende e Arroio, 2008). Os alunos assistiram ao filme e, após, foram orientados a responder questionamentos a respeito do mesmo através de um debate.

Utilizamos esse tipo de recurso porque a linguagem do filme possibilita ao professor deixar de ser um informador, passando a ser um mediador que fomenta a autonomia do aluno. A imagem mostra-se mais eficaz do que a palavra na hora de provocar emoções. Sendo assim, o vídeo desempenha um papel importante, com sua capacidade de provocar emoções e sensações (Arroio e Giordan, 2006) 


\subsubsection{3- ESTUDO DIRIGIDO SOBRE O TEMA, ELABORAČ̃̃O DE QUESTÕES E} DISCUSSÕES SOBRE AS QUESTÕES

Os professores solicitaram que os alunos levassem material de pesquisa com um tema pré-determinado (livros, apostilas, enciclopédias, material pesquisado da internet, entre outros) para a sala de aula. Os professores separaram os alunos em grupos com quatro componentes, para a realização de um estudo dirigido (Anexo $\mathrm{C}$ ), que culminou com a proposição de questões elaboradas pelos próprios alunos (Anexo D). Estas perguntas foram utilizadas, pelo professor, para a elaboração do jogo de tabuleiro por serem importantes para a compreensão do tema enfocado. Esta etapa foi finalizada através de uma discussão em grupos, tornando possível o esclarecimento de algumas dúvidas a respeito da temática. Após estas etapas e todo o processo, que durou oito horas-aula, os alunos foram apresentados ao jogo e suas respectivas regras.

\subsubsection{CRIACÃO E DESENVOLVIMENTO DE UM PROTÓTIPO: O AUTÓDROMO}

\section{$\underline{\text { ALQUÍMICO }}$}

Durante a etapa de criação e desenvolvimento das alternativas de jogos foi feita uma revisão da literatura sobre os tipos de jogos, como aparecem nos Capítulos 4 e 6, deste estudo e foram trabalhadas as possibilidades de aplicação e desenvolvimento de uma atividade lúdica abordando essa temática. Nem todas as idéias foram positivas, constatando-se que muitas das possibilidades remontavam a jogos que envolviam os níveis de cognição mais elementares, sendo necessária a adoção e seleção de algumas propostas (Antunes, 2003). Dentre estas idéias, foram feitos alguns esboços até que se escolheu a opção mais interessante no que se refere à proposta de oferecer um ambiente criativo, prazeroso, motivacional e crítico, atendendo às necessidades do desenvolvimento de algumas habilidades necessárias aos alunos (Antunes, 2003). Logo, optou-se pela criação de um jogo conhecido por autódromo (Antunes, 1987), que é uma metodologia lúdica que utiliza perguntas e respostas para a sua execução, à medida que os alunos acertam 
as respostas vão acumulando pontos para posterior vitória. O vencedor é aquele que obtiver a maior pontuação ao final do jogo (Santana e Rezende, 2007) após somatória das respostas corretas. Posteriormente denominamos o nosso autódromo de Autódromo Alquímico, pois o mesmo irá desenvolver as FPS a partir da temática alquimia e química e as diferentes formas de se trabalhar com as transformações dos materiais.

O Autódromo Alquímico é um jogo de tabuleiro, semelhante a uma corrida de carrinhos, que se refere ao tema Alquimia (Figura 6.3). Este jogo desenvolve (Antunes, 2003) nos alunos habilidades tais como: saber conviver em grupo; saber lidar com regras e com previsibilidade; respeito às identidades e diferenças; inter-relação de pensamentos, idéias e conceitos; desenvolvimento da criatividade e da capacidade de argumentação, além de aumentar a interação entre os alunos e entre eles e o professor (Brasil, 2002).

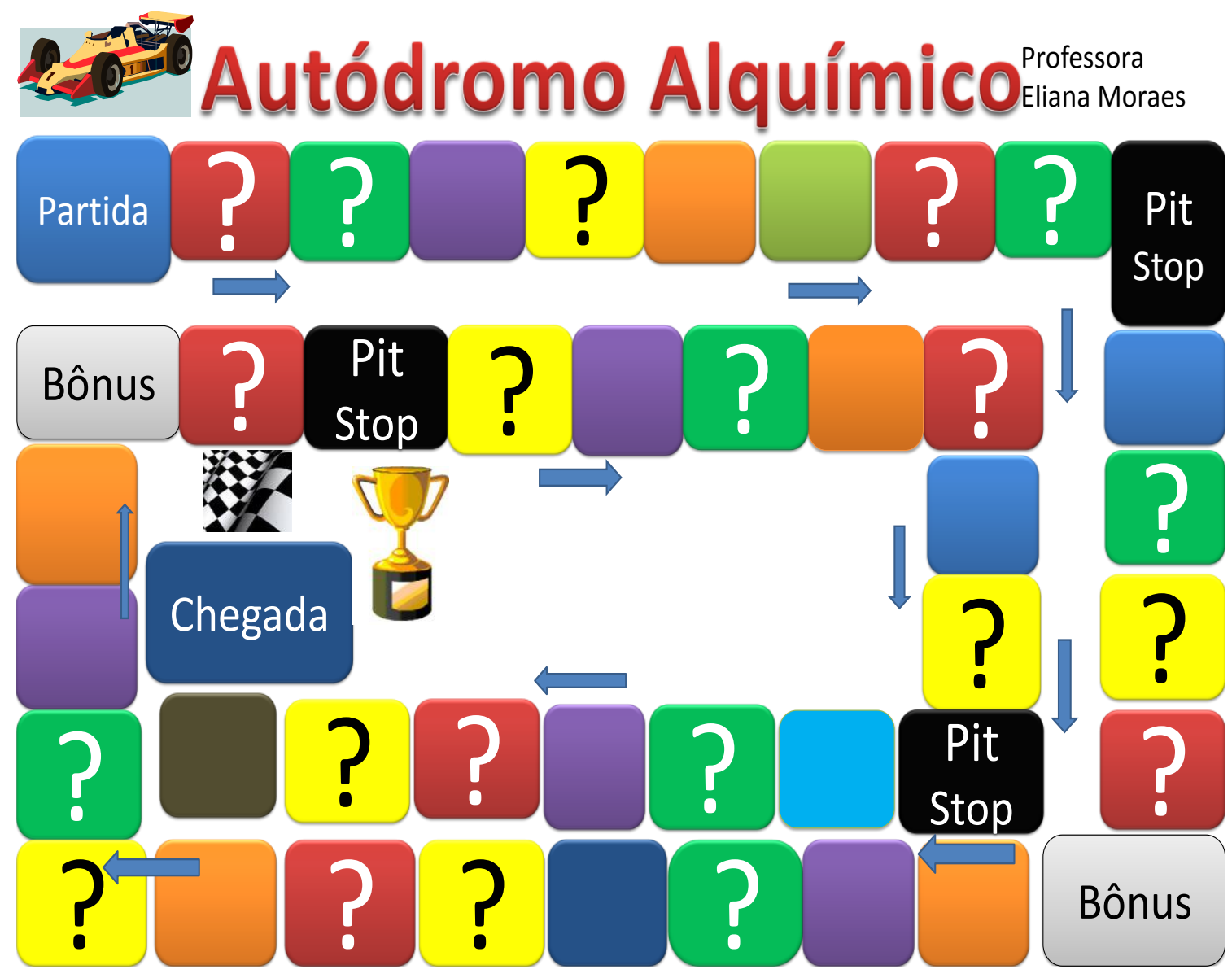

Figura 6.3: Tabuleiro do Autódromo Alquímico 
6.2.1.5 MODELO DE ESTRUTURA DO PROTÓTIPO DE JOGO E DESENVOLVIMENTO DOS MATERIAIS

Criar um modelo de estrutura de jogo passível de aplicação em ambiente de sala de aula constituiu um desafio de percurso. $O$ jogo deveria estimular a participação, criar motivação e, ao mesmo tempo, ser factível para a realização por grupos maiores em trabalho simultâneo. A professora sugeriu que fossem aplicadas em grupos de, no máximo, quatro pessoas. Nesse caso, o fator tempo é determinante: considerando a disponibilidade de cinqüenta minutos de duração de uma aula, seriam 100 minutos por semana, pois as aulas de química na escola são duplas (dois horários seguidos).

$\mathrm{Na}$ criação do jogo, foi definida a utilização dos seguintes elementos: um tabuleiro (Figura 6.3), cartas vermelhas, amarelas e verdes, que representam as perguntas nos diferentes níveis (Anexo D); cartas brancas, representando as cartas-bônus; quatro carrinhos com cores distintas, para representar cada aluno em seu respectivo jogo; um dado comum de seis faces. Nesta proposta, os alunos formaram os grupos com quatro pessoas, para trabalharem cooperativamente na resolução do problema proposto pelo jogo. O caráter competitivo fica estabelecido entre esses grupos.

Nas primeiras aplicações, o tabuleiro foi confeccionado em uma cartolina, com pequenos quadrados coloridos que foram colados formando a pista do autódromo. Posteriormente, os tabuleiros foram impressos em lona para aumentar a durabilidade dos mesmos, facilitando também o trabalho do professor. Os carrinhos e dados foram comprados pelo professor, sendo peças de maior durabilidade, se comparadas ao restante dos materiais. As cartas contendo as questões foram confeccionadas pelo próprio professor, porém as perguntas foram elaboradas pelos alunos (Anexo $\mathrm{C}$ ). O material utilizado foi papel cartão impresso, forrado com papel contact, para conferir maior durabilidade aos cartões, facilitando a manipulação dos mesmos. As cores do papel cartão utilizado foram: vermelho, verde, amarelo e branco, pois isso iria identificar o grau de dificuldade de cada carta. E, por último, foi necessária a confecção de caixas para serem guardados os jogos em seus respectivos lugares. 


\subsubsection{DEFINICOÕES DAS REGRAS DE FUNCIONAMENTO}

Em linhas gerais, o jogo deverá seguir a seguinte dinâmica (Santana 2006):

1) para iniciar a atividade, separa-se a sala em grupos e distribuem-se as caixas ${ }^{1}$ contendo os jogos, regras, instruções, tabuleiro, perguntas e carrinhos, para cada equipe, possibilitando a montagem do jogo pelos alunos;

2) antes do início da partida, os jogadores, em grupos, recebem as instruções mediante exposição do professor sobre as regras e dinâmica do jogo;

3) começa jogando o aluno que conseguir maior pontuação ao lançar o dado;

4) as perguntas no jogo diferem quanto ao nível de dificuldade, cujo grau é indicado em analogia às cores dos semáforos de trânsito. As verdes são de nível mais básico, as amarelas intermediárias e, as vermelhas, apresentam um nível mais alto de elaboração, como é mostrado na Figura 6.3, que as mostra indicadas por interrogações no tabuleiro, classificadas segundo este código de cores. É importante ressaltar que as questões foram elaboradas primeiramente pelos grupos durante a aplicação da oficina ( Anexos D e E);

5) quando os alunos vão superando as dificuldades e respondendo as perguntas com distintos níveis de complexidade, os colegas do grupo julgam a coerência das respostas e decidem se as mesmas estão corretas ou não; se estiverem corretas, eles vão ultrapassando os colegas. Por exemplo, ao acerto de uma pergunta verde corresponde o avanço de uma casa, enquanto o erro implica no correspondente retorno. O mesmo acontece com as perguntas amarelas só que, ao invés de avançar ou retornar uma casa, eles vão avançar/ retornar duas enquanto, para as perguntas vermelhas, o número de casas que serão avançadas ou retrocedidas é igual a três, devido ao nível de dificuldade das questões;

6) não é permitido o uso de material de consulta;

7) existem, também, na pista do autódromo, o pit stop e a carta-bônus; o primeiro significa que a equipe/aluno deve ficar uma rodada sem jogar; já, na

\footnotetext{
${ }^{1}$ No caso da aplicação com tabuleiro pequeno, antes de se passar para o tabuleiro gigante.
} 
carta-bônus, o aluno escolhe um envelope que contém a indicação do número de casas que ele pode avançar ou retornar, ou uma pergunta bônus que será respondida ou ainda um enigma a ser decifrado. O aluno (ou equipe) que chegar primeiro ao final da pista de corrida é o vencedor.

\subsubsection{APLICACCÃO DO JOGO: AUTÓDROMO ALQUÍMICO}

A primeira aplicação deste jogo gerou diversas discussões, das quais surgiu a idéia de se montar uma pista de corrida gigante, com as casas do tamanho de uma cartolina, em que os alunos seriam os carrinhos da pista (Figuras $6.4 \mathrm{e}$ 6.5), sendo montada na quadra da escola. Observa-se que ocorreu uma evolução das regras do Autódromo pelos próprios alunos, o que podemos classificar como pertencendo ao quarto nível de interação de acordo com Soares (2008). As turmas que participaram do autódromo gigante foram a A, B e C (aplicação-piloto); nas turmas D, E, F, G, (Figura 6.6) H e I (Figura 6.7), a aplicação do jogo foi realizada com o tabuleiro pequeno, em grupos de quatro componentes.

A aplicação-piloto permitiu testar o jogo e ajustar algumas regras. O pósteste das turmas-piloto ( $A, B$ e $C$ ) foi realizado juntamente com o provão da unidade e não através de um instrumento específico, como aconteceu com as demais turmas.

Logo após essa aplicação das demais turmas, ou seja, uma semana depois, os alunos fizeram análise diagnóstica final que serviu de pós-teste, composto por duas questões discursivas a respeito da temática (Anexo F).

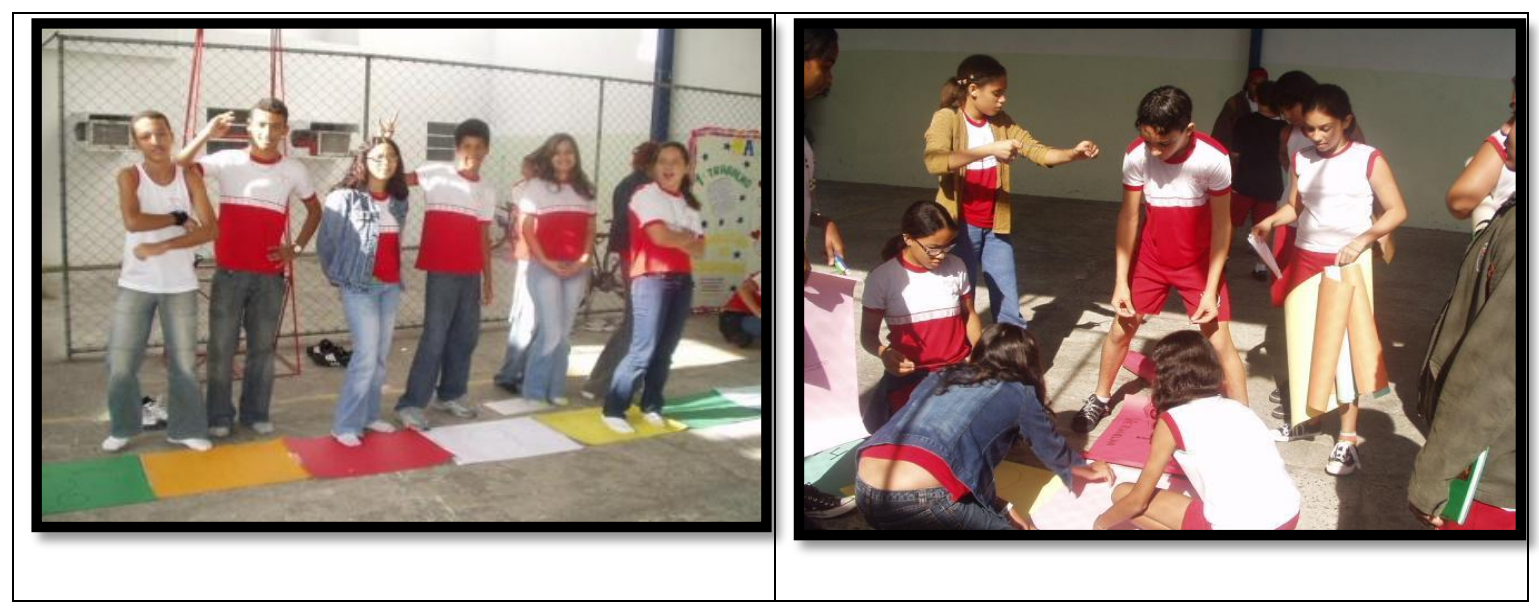




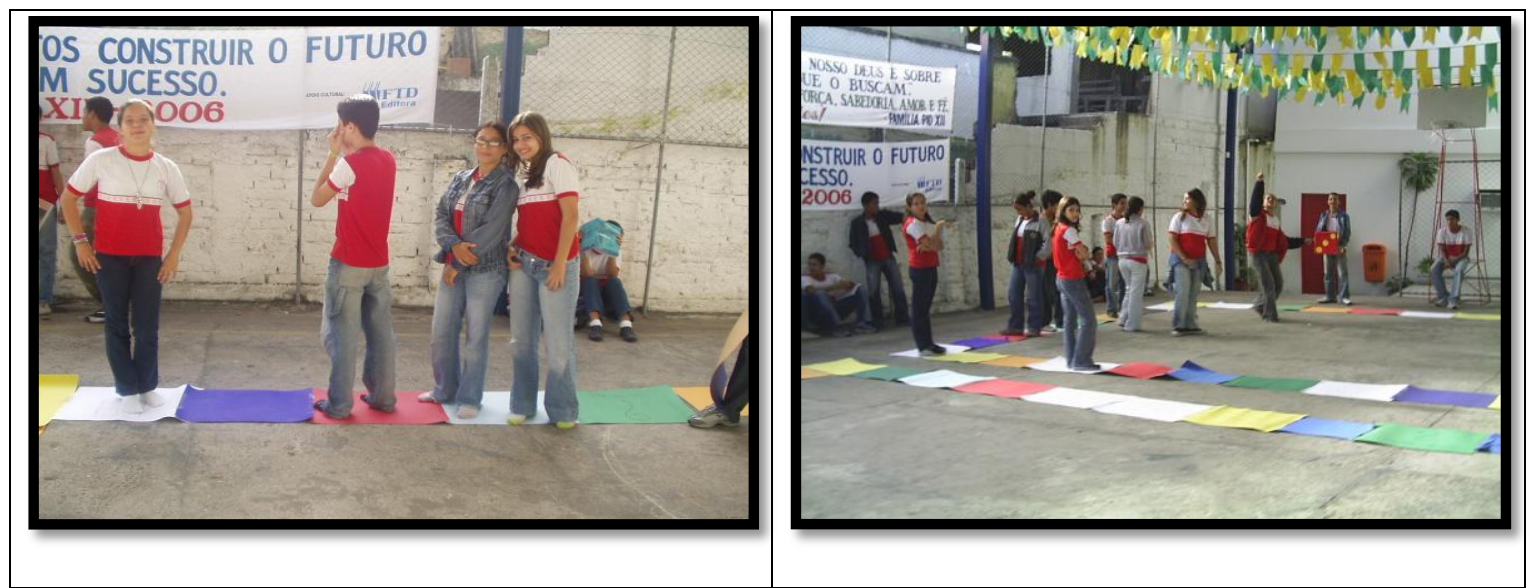

Figura 6.4: Montagem e aplicação-piloto do Autódromo Alquímico gigante (turma piloto A).

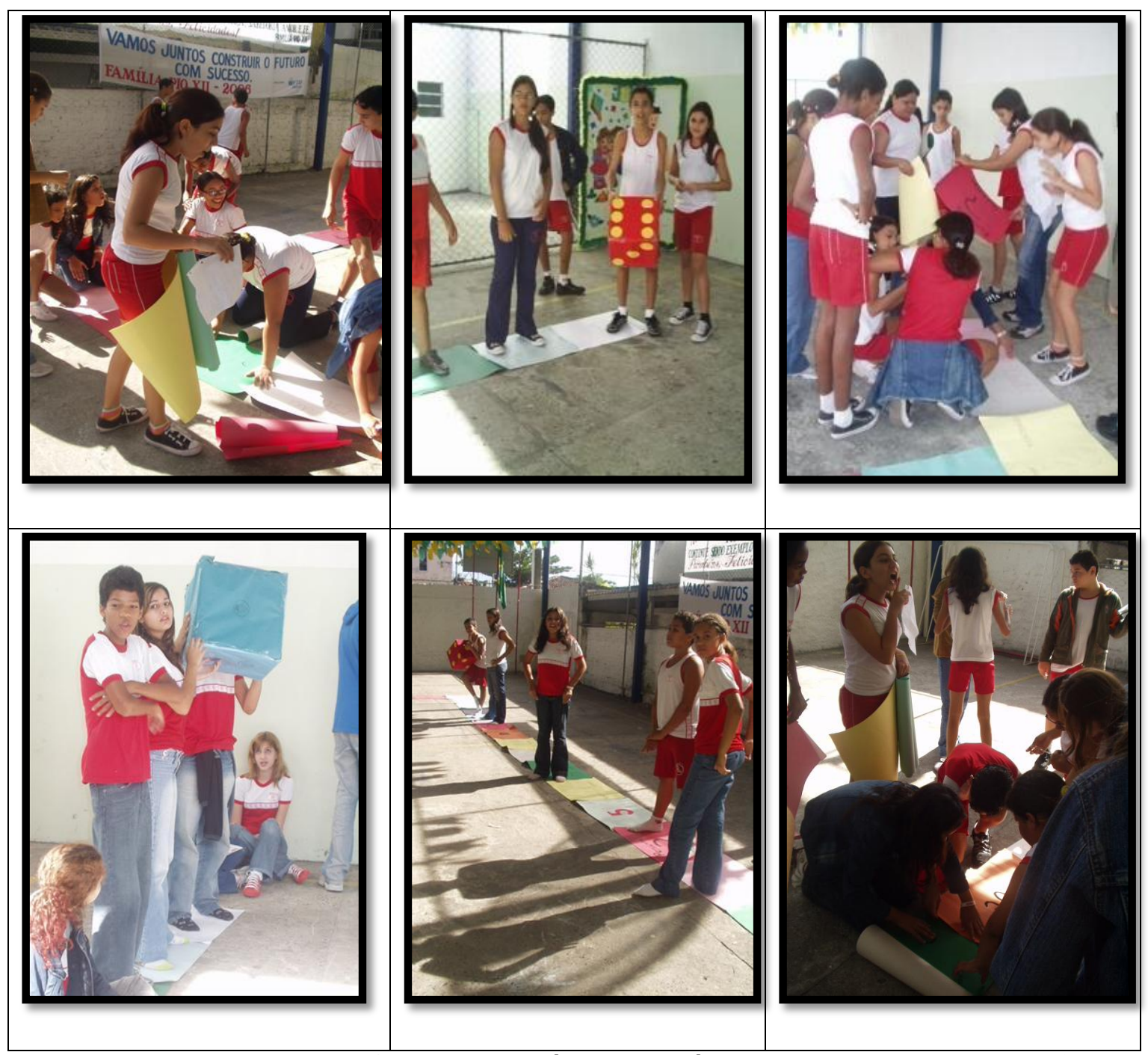

Figura 6.5: Montagem e aplicação-piloto do Autódromo Alquímico gigante (turmas piloto B e C) 

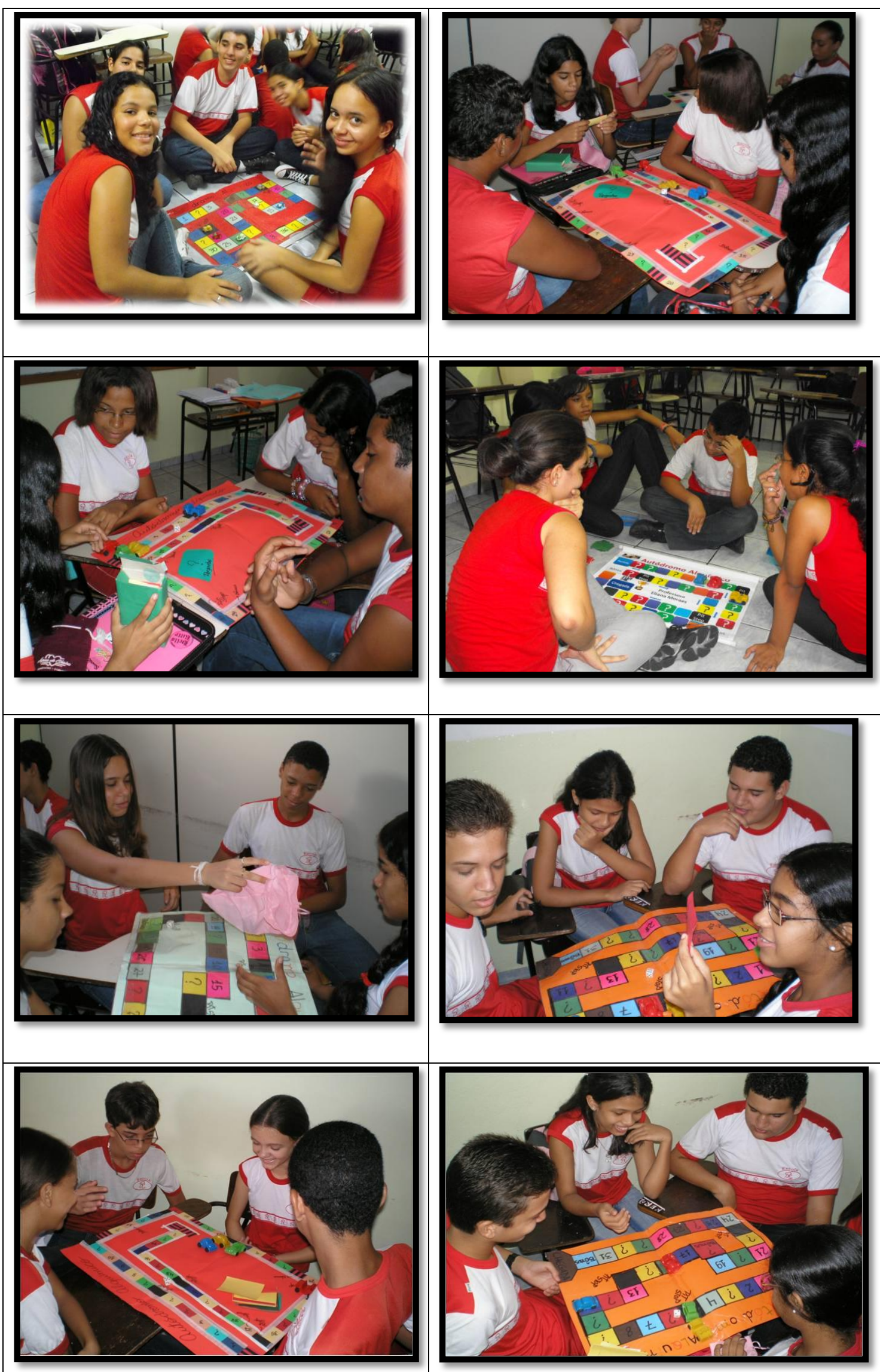

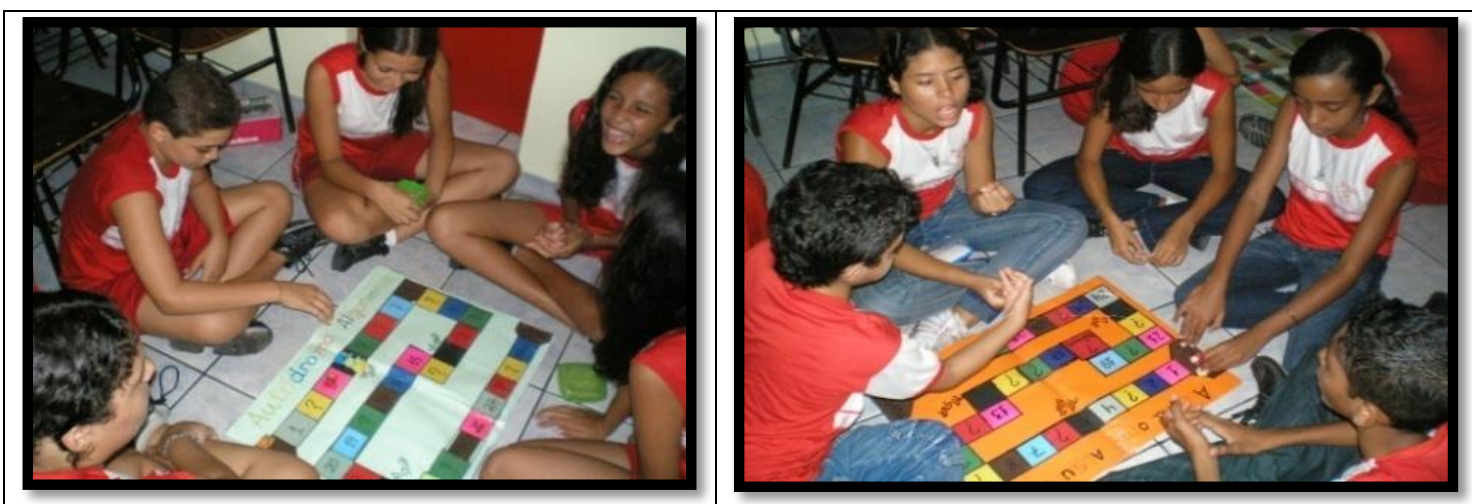

Figura 6.6: Aplicação do Autódromo Alquímico em equipes (Turmas D, E, Fe G)
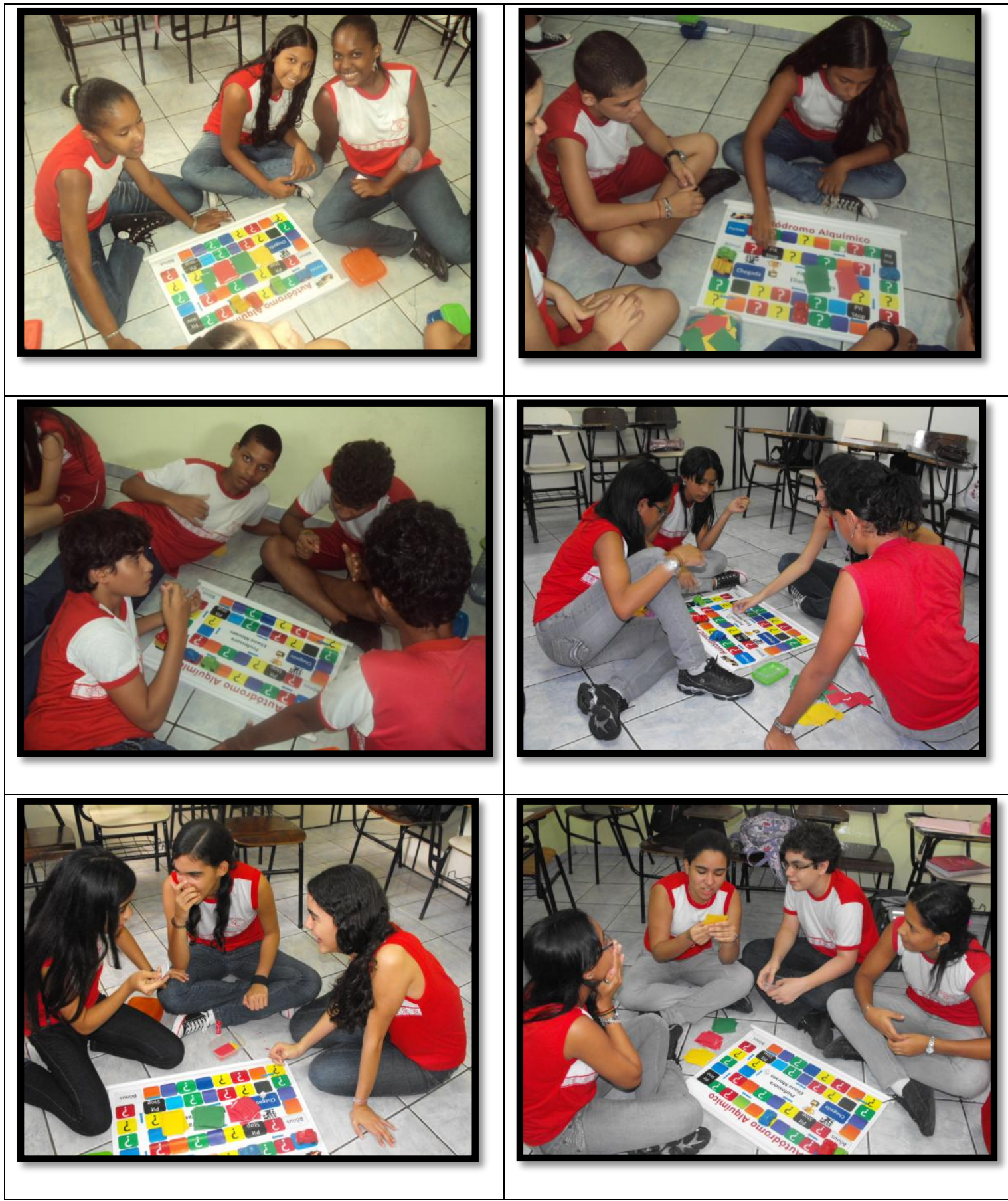


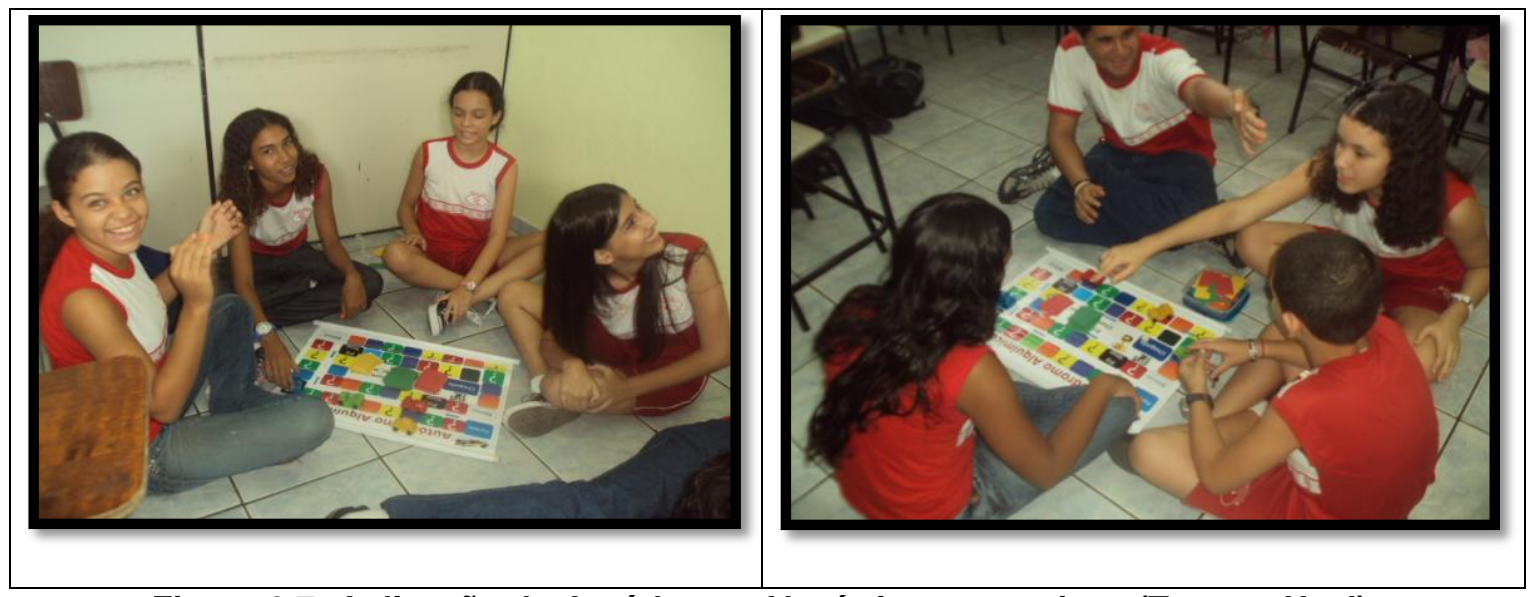

Figura 6.7: Aplicação do Autódromo Alquímico em equipes (Turmas H e l).

\section{3- Coleta e Análise dos Dados da atividade}

\subsubsection{FONTES DE DADOS}

No presente trabalho, os dados são construídos, através de técnicas de análise do conteúdo (Bardin, 2000), a partir das fontes empregadas para a coleta de informações. Nesta Dissertação, foram empregados diversos recursos investigativos, com o objetivo de se fazer uma triangulação dos dados, a saber:

- avaliação diagnóstica, dividida em três momentos durante todo 0 processo de aplicação (Anexos A a F; Figura 6.8);

- filmagens, posteriormente transcriadas; ${ }^{2}$

- entrevistas e questionários (Anexos G e H) , realizados após todo o processo do jogo.

Nos pré-testes aplicados em todas as turmas (Anexo A) foi solicitado que os alunos escrevessem a respeito de quatro palavras (Alquimia, Alquimistas, Pedra Filosofal e Química). Essa avaliação diagnóstica inicial foi aplicada logo no primeiro contato com a turma, para verificar os conhecimentos prévios dos alunos a respeito da temática envolvida no jogo. A avaliação continuada

\footnotetext{
2 "operação radical de tradução" (CAMPOS, 1981) - Deus e o diabo no fausto de Goethe. São Paulo: Perspectiva, 1981. CAMPOS, H. Da tradução como criação e como crítica In: Metalinguagem e outras metas . $4^{\mathrm{a}}$ ed. São Paulo: Perspectiva, 1992.
} 
(Anexos B-E) foi realizada para ser comparada à inicial, sendo realizada durante o processo. Logo após o encerramento de todas as etapas constituintes do jogo, foi realizada a análise diagnóstica final (Anexo F).

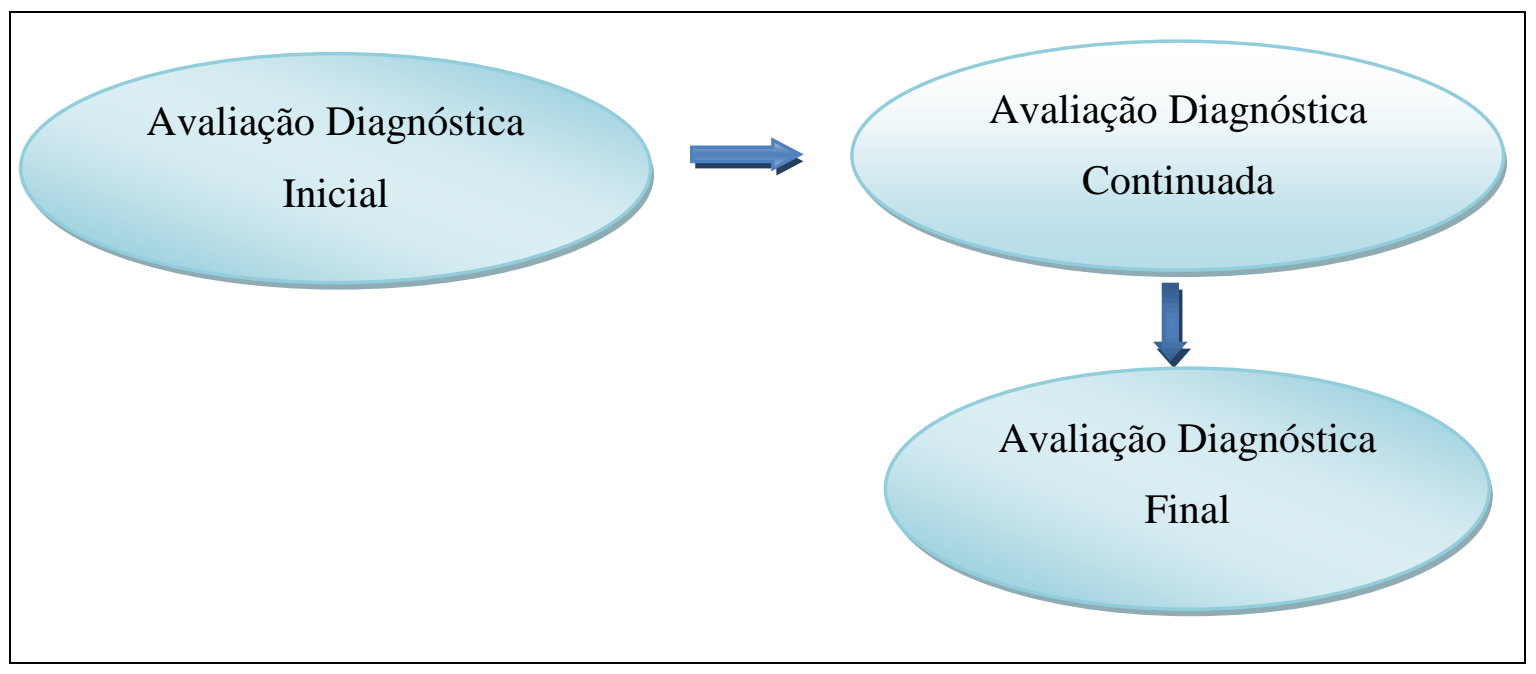

Figura 6.8: Tipos de Avaliações Diagnósticas

Entretanto, os instrumentos diagnósticos em si não são adequados para a compreensão das interações entre os sujeitos durante o processo em que os conceitos são ressignificados. Com a intenção de analisar essas interações dos alunos durante $o$ jogo, foram feitas filmagens que representaram as etapas 3 até 7 (Questionamentos sobre o filme, estudo dirigido sobre a temática, elaboração das questões, discussões sobre as questões e dúvidas e o jogo Autódromo Alquímico), posteriormente foram transcritas essas etapas (tabela 6.2).

As filmagens escolhidas para serem usadas nos resultados desse estudo foram os filmes das turmas de 2009 e 2010 (F, G, H e I) por serem mais significativas para toda a pesquisa. Os alunos interagiram com maior facilidade nessas turmas devido à professora ter interferido na escolha dos grupos. Nas turmas anteriores, os próprios alunos escolhiam os componentes do seu grupo, porém, foi observada a formação das famosas "panelinhas", ou seja, grupos formados pela escolha de componentes por maior afinidade e aproximação. Foi observado que esse fator foi prejudicial em certo ponto para a pesquisa, pois, observou-se uma grande evolução em alguns grupos e uma pequena interação entre outros grupos que não estavam muito familiarizados. 
A interferência e mediação da professora foi importante no processo de escolha dos grupos, pois serviu para um melhor desenvolvimento de habilidades em diferentes níveis de cognição em que se encontravam os alunos.

Além dessas avaliações diagnósticas, que analisaram o processo de desenvolvimento do jogo quanto à ressignificação dos conceitos, os professores acharam pertinente que os alunos também avaliassem o jogo de uma forma geral, através de um questionário (anexo G) e de uma entrevista (anexo $\mathrm{H}$ ).

Esses questionários aplicados ao final do processo serviram para analisar a função do jogo, bem como a opinião dos discentes em relação à metodologia diferenciada utilizada no processo. Foram analisadas as respostas e as mesmas serão apresentadas em forma de gráficos com as respectivas análises.

Nas entrevistas que foram gravadas em áudio, foram escolhidos alguns trechos a serem transcritos e analisados, outros fatores em comum entre os entrevistados, possibilitando posterior análise de dados e resultados e discussão.

\subsubsection{Análise de conteúdo}

A análise de conteúdo é uma técnica que visa identificar o que está sendo falado a respeito de determinado tema. Valentim (2005) aponta em suas pesquisas que esse tipo de análise utiliza, basicamente, materiais textuais escritos. Comumente em diversos tipos de pesquisas, quando realizadas as coletas de dados aparecem predominantemente dois tipos de textos básicos, os primeiros são textos construídos durante o processo de pesquisa, tais como: transcrições de filmagens, entrevistas e protocolos de observação, podendo ser analisados outros meios como diários de campo e anotações dos professores, o segundo tipo de texto são os que foram produzidos para outra finalidade específica, como análise diagnósticas iniciais, continuadas e finais. 
Segundo Puglisi e Franco (2005) na análise de conteúdo o ponto de partida é a mensagem, porém ao analisá-la é necessário levar em consideração o contexto em que os produtores estão envolvidos e na concepção crítica e dinâmica da linguagem, priorizando assim as interações sociais representadas por interações dialógicas dos sujeitos envolvidos em todo processo de análise.

\section{Número de Pessoas Implicadas na Comunicação}

\begin{tabular}{|c|c|c|c|c|}
\hline $\begin{array}{l}\text { Código e } \\
\text { Suporte }\end{array}$ & $\begin{array}{l}\text { Uma pessoa } \\
\text { "Monólogo" }\end{array}$ & $\begin{array}{l}\text { Comunicação } \\
\text { "Diálogo" }\end{array}$ & Grupo Restrito & $\begin{array}{c}\text { Comunicação em } \\
\text { Massa }\end{array}$ \\
\hline
\end{tabular}

\section{Linguístico}

\begin{tabular}{|c|c|c|c|c|}
\hline Escrito & $\begin{array}{l}\text { agendas, maus } \\
\text { pensamentos, } \\
\text { conjecturas, } \\
\text { diários íntimos. }\end{array}$ & $\begin{array}{c}\text { cartas, } \\
\text { respostas a } \\
\text { questionários, } \\
\text { a testes } \\
\text { projetivos, } \\
\text { trabalhos } \\
\text { escolares. }\end{array}$ & $\begin{array}{l}\text { ordens de serviço numa } \\
\text { empresa, todas as } \\
\text { comunicações escritas } \\
\text { trocadas dentro de um } \\
\text { grupo. }\end{array}$ & $\begin{array}{l}\text { jornais, livros, } \\
\text { revistas, anúncios } \\
\text { publicitários, } \\
\text { cartazes, literatura, } \\
\text { textos jurídicos e } \\
\text { panfletos. }\end{array}$ \\
\hline Oral & sonhos & $\begin{array}{l}\text { entrevistas e } \\
\text { conversações } \\
\text { de qualquer } \\
\text { espécie. }\end{array}$ & $\begin{array}{l}\text { discussões, entrevistas, } \\
\text { conversações de grupo de } \\
\text { qualquer natureza. }\end{array}$ & $\begin{array}{l}\text { exposições, } \\
\text { discursos, rádio, } \\
\text { televisão, cinema, } \\
\text { publicidade, mp3, } \\
\text { cds e dvds. }\end{array}$ \\
\hline
\end{tabular}

\begin{tabular}{|c|c|c|c|c|}
\hline Icônico & & & & \\
\hline $\begin{array}{l}\text { Sinais, } \\
\text { grafismos, } \\
\text { imagens, } \\
\text { fotografias, } \\
\text { filmes, etc. }\end{array}$ & $\begin{array}{c}\text { rabiscos mais } \\
\text { ou menos } \\
\text { automáticos. } \\
\text { grafitos,sonhos. }\end{array}$ & $\begin{array}{l}\text { respostas aos } \\
\text { testes } \\
\text { projetivos, } \\
\text { comunicação } \\
\text { entre duas } \\
\text { pessoas } \\
\text { através da } \\
\text { imagem. }\end{array}$ & $\begin{array}{c}\text { toda a comunicação } \\
\text { icônica num pequeno } \\
\text { grupo (símbolos icônicos } \\
\text { numa sociedade secreta, } \\
\text { numa casta) }\end{array}$ & $\begin{array}{l}\text { sinais de trânsito, } \\
\text { cinema, } \\
\text { publicidade, } \\
\text { pintura, cartazes, } \\
\text { televisão. }\end{array}$ \\
\hline
\end{tabular}

\begin{tabular}{|c|c|c|c|}
\hline \multicolumn{4}{|c|}{ Outros Códigos Semióticos } \\
\hline $\begin{array}{l}\text { aquilo que, não } \\
\text { sendo lingüístico, } \\
\text { pode ter } \\
\text { significações } \\
\text { (música, código } \\
\text { olfativo, objetos } \\
\text { diversos, } \\
\text { comportamentos, } \\
\text { espaço, tempo, } \\
\text { sinais } \\
\text { patológicos, etc.) }\end{array}$ & $\begin{array}{c}\text { manifestações histéricas da } \\
\text { doença mental, posturas, gestos, } \\
\text { tiques, dança, coleções de } \\
\text { objetos. }\end{array}$ & $\begin{array}{l}\text { comunicação não verbal } \\
\text { com destino a outrem } \\
\text { (posturas, gestos, distância } \\
\text { espacial, sinais olfativos, } \\
\text { manifestações emocionais, } \\
\text { objetos cotidianos, } \\
\text { vestuário, alojamento), } \\
\text { comportamentos diversos, } \\
\text { tais como os ritos e as } \\
\text { regras de cortesia. }\end{array}$ & $\begin{array}{c}\text { meio físico e } \\
\text { simbólico: } \\
\text { sinalização urbana, } \\
\text { monumentos, } \\
\text { arte...; mitos, } \\
\text { estereótipos, } \\
\text { instituições, } \\
\text { elementos de } \\
\text { cultura. }\end{array}$ \\
\hline
\end{tabular}

Quadro 6.1: Domínios possíveis da aplicação da análise de conteúdo (Valentim, 2005)

Ao se observar o tipo de análise a ser realizada deve ser priorizado a interpretação do sentido que um indivíduo atribui às mensagens. De acordo com Machado (1991) a análise do conteúdo assemelha-se ao processo de 
categorização e tabulação de respostas a questões abertas. Criada inicialmente como uma técnica de pesquisa objetiva, sistemática e quantitativa de comunicações, atualmente é utilizada cada vez mais empregada para análise de material qualitativo obtido através da coleta de dados realizadas na pesquisas, como a utilizada nesse relato.

Algumas vantagens ao se utilizar o método referem-se à possibilidade de lidar com grandes quantidades de dados, além de se fazer uso, principalmente, de dados brutos, que ocorrem naturalmente. Possui também um conjunto de procedimentos maduros e bem documentados e o pesquisador caminha através da seleção, criação de unidades e categorização desses dados (Bauer e Gaskell, 2002).

A análise pode ser dividida em três fases: pré-análise, análise propriamente dita e tratamento de dados, devendo ser norteada por objetivos específicos (Bardin, 2000). A primeira fase é chamada pré-análise, que pode ser realizada em duas etapas: análise textual e temática. Na segunda fase é realizada a etapa de análise propriamente dita, ocorre à exploração do material, através de releitura para a identificação e categorização dos elementos de análise. Finalmente, faz-se o tratamento dos resultados, sendo a última fase de análise composta por inferência e a interpretação. Valentim (2005) especifica, ainda, os domínios possíveis ao se realizar análise de conteúdo, explicitando as possibilidades e as comparando entre si (Quadro 6.1).

Entre as técnicas utilizadas para a realização da análise de conteúdo, destacam-se dois tipos, a análise léxica e a análise categorial. A análise léxica tem como material de análise as próprias unidades de vocabulário, as palavras portadoras de sentido relacionadas ao objeto de pesquisa. A análise categorial trata do desmembramento do discurso em categorias, em que os critérios de escolha e de delimitação orientam-se pela dimensão da investigação dos temas relacionados ao objeto de pesquisa, identificados nos discursos dos sujeitos pesquisados.

O processo de coleta e análise de dados pode ser entendido a partir dos diagramas apresentados nas Figuras 6.9, 6.10 e 6.11 que representam as três fases da análise. Em sua fase inicial (Figura 6.9) inicia-se a partir dos objetivos da pesquisa que são a base para a construção do instrumento de coleta de 
dados. Nessa fase, é importante que se observem as possíveis técnicas da análise de conteúdo. Feito isso, deve-se constituir o corpus central que apoiará a análise de dados, etapa posterior à coleta de dados. A constituição do corpus é possível a partir da leitura e análise da literatura selecionada, permitindo criar inferências em relação ao objeto e ao seu entorno (Valentim, 2005).

A segunda fase (Figura 6.10) do processo de coleta e análise de dados parte das subcategorias essenciais, definidas na etapa anterior, às quais se somam as inferências do pesquisador referentes ao objeto de pesquisa, visando-se construir o segundo instrumento de coleta de dados, a entrevista. Nessa fase, as inferências são fundamentais para a construção dos tópicos do instrumento, pois é a partir delas que é possível estabelecer as dimensões e relações para a análise, que possibilitará a construção de novo corpus teórico.

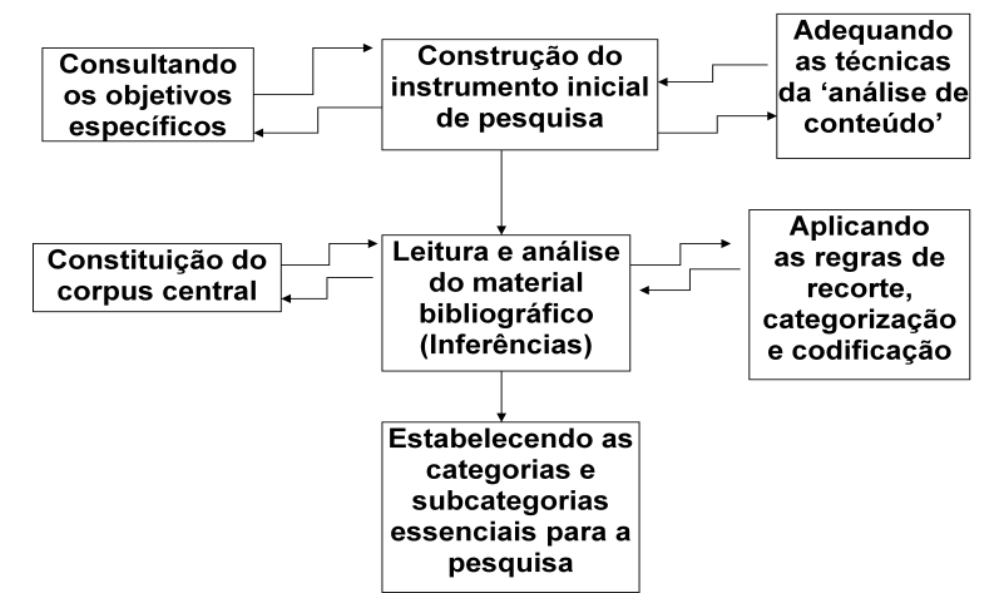

Figura 6.9: Processo de Coleta de Análise de Dados - Fase Inicial (Valentim, 2005)

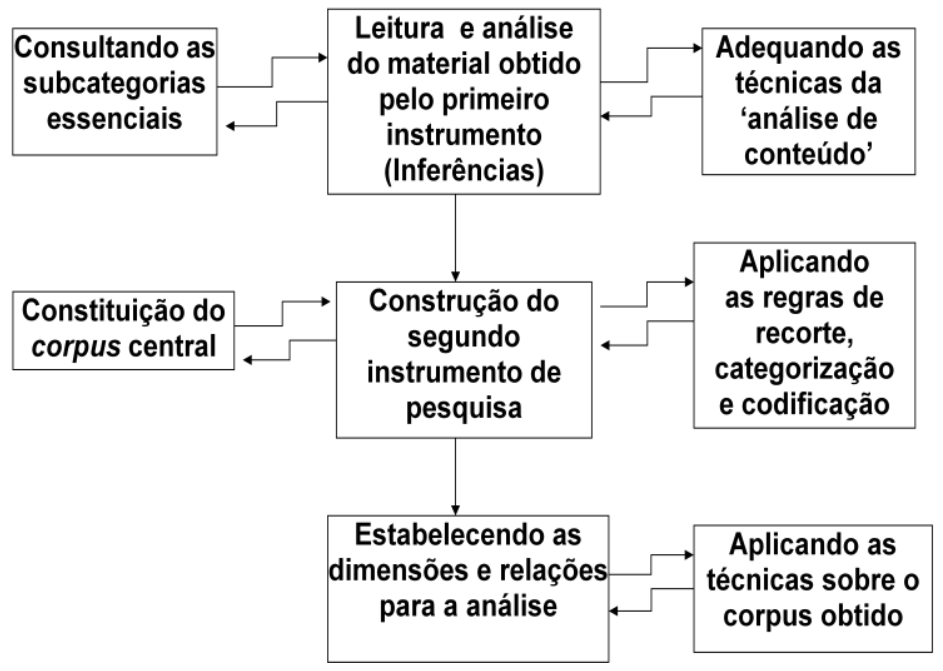

Figura 6.10- Processo de Coleta de Análise de Dados - Fase Intermediária (Valentim, 2005) 
A terceira e última fase do processo de coleta e análise de dados parte do corpus teórico construído, para realizar a interpretação da análise. Novas inferências poderão ser feitas pelo pesquisador em relação ao objeto de pesquisa, mesmo que não tenham sido previstas. No entanto, as interpretações devem estar apoiadas em provas de validação, isto é, na própria literatura de especialidade ou nas práticas observadas no ambiente pesquisado. Nessa fase, a interpretação é essencial, mas deve estar claramente relacionada ao corpus existente, de modo que seja validada pela comunidade científica da área. Finalmente, sistematizar os resultados com os objetivos iniciais, buscando a construção de conhecimento científico sobre o objeto pesquisado (Figura 6.11).

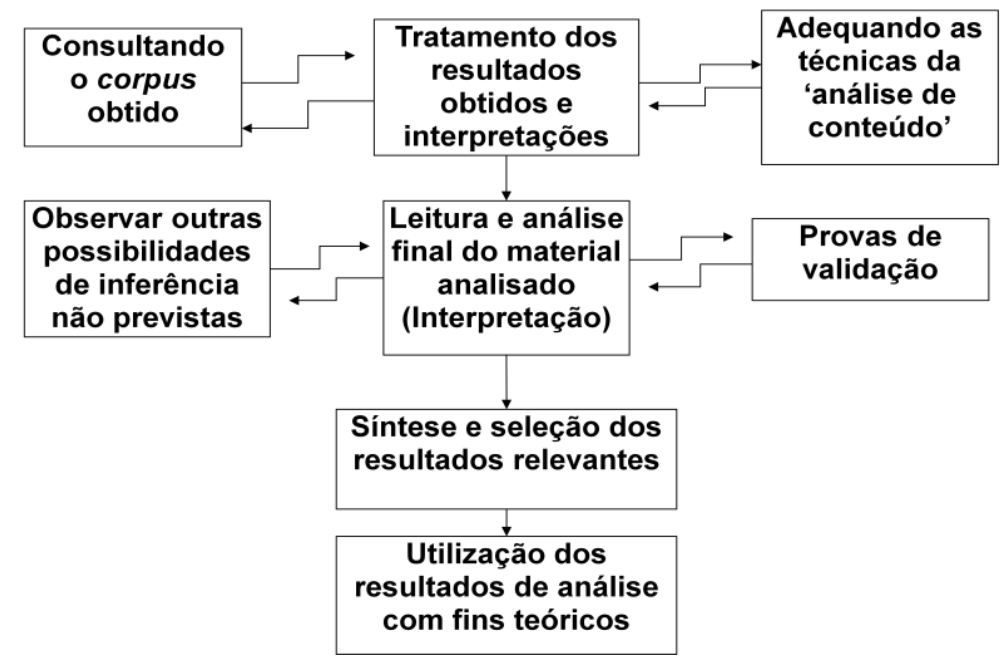

Figura 6.11- Processo de Coleta de Análise de Dados - Fase Final (Valentim, 2005)

A partir da análise dos instrumentos diagnósticos e da análise de conteúdo (Bardin, 2000), tornou-se possível a criação de sete categorias para o enquadramento e classificação das respostas dos alunos presentes nas três análises diagnósticas. A categorização das respostas foi realizada a partir das evocações registradas por eles para cada uma das palavras empregadas (Bardin, 2000; Tabela 6.3). Estas categorias espelham as convergências e divergências entre alquimia e química durante o desenvolvimento das etapas metodológicas, permitindo que se percebam a ampliação e evolução dos conceitos desenvolvidos durante o jogo. 
Tabela 6.3: Categorias construídas para as análises diagnósticas

\section{CATEgorias}

Transformação: Relacionado à mudança de formas e ocorrência de reações;

Pré- Química: Relativo à evolução da Alquimia em Química;

Magia: Arte tida como capaz de produzir, por meio de certas práticas ocultas, efeitos que contrariam as leis naturais.

Experimentação: Quando for relacionada a todos os aspectos que envolvem diversos experimentos;

Saberes: Quando ocorrer uma soma de conhecimentos, ilustração, cultura, erudição.

Motivações: Fator que determina o comportamento das pessoas;

Conceitualização :É uma Idéia que uma pessoa faz de uma classe de objetos.

As categorias e subcategorias eleitas e que aparecem na Tabela 6.3 serão analisadas de acordo com as FPS de Vygotsky (2005; 2007). A emoção, abstração, imaginação, percepção, generalização, memória, atenção, o pensamento, linguagem e a criatividade formam o conjunto das funções psicológicas superiores destacadas neste trabalho. Tornou-se necessário uma definição específica de cada uma das FPS para posterior análise das filmagens, facilitando assim a identificação dos trechos em que ocorre o desenvolvimento dessas funções (Tabela 6.4).

Tabela 6.4: Especificidades das Funções Psicológicas Superiores

\begin{tabular}{|c|c|}
\hline & Definição de cada Função Psicológica Superior (FPS) \\
\hline Emoção & $\begin{array}{l}\text { Toda emoção é uma chamada à ação ou uma renúncia a ela. Nenhum } \\
\text { sentimento pode permanecer indiferente e improdutivo no } \\
\text { comportamento. As emoções são os organizadores internos das } \\
\text { reações, que retesam, excitam, estimulam ou inibem o papel de } \\
\text { organizador do comportamento do ser humano. }\end{array}$ \\
\hline Abstração & $\begin{array}{l}\text { Ação ou efeito de abstrair; } \\
\text { Imagem mental subjetiva. }\end{array}$ \\
\hline Imaginação & $\begin{array}{l}\text { Faculdade mental de evocar, sob a forma de imagem, objetos ou fatos } \\
\text { conhecidos por percepção ou experiência anteriores; } \\
\text { Capacidade de elaborar imagens, concepções, idéias e soluções novas; } \\
\text { Função pela qual a mente vê e representa sob uma forma sensível e }\end{array}$ \\
\hline
\end{tabular}




\begin{tabular}{|c|c|}
\hline & ta, seres, coisas, situação das quais não teve exper \\
\hline Percepção & $\begin{array}{l}\text { Apreensão, por meio do sentido e da mente; capacidade de } \\
\text { compreensão. }\end{array}$ \\
\hline Generalização & $\begin{array}{l}\text { Torna-se geral, comum a muitas pessoas, propagar-se, tornar-se mais } \\
\text { amplo. }\end{array}$ \\
\hline Memória & $\begin{array}{l}\text { Faculdade de reter na mente idéias, impressões e conhecimentos } \\
\text { adquiridos anteriormente; Dissertação, relato, narração sobre o assunto } \\
\text { científico, podendo existir diversos tipos: memória coletiva, permanente, } \\
\text { principal, visual e volátil. } \\
\text { A memória é um mediador do comportamento porque, através dela, as } \\
\text { experiências passadas influenciam o que fazemos no presente. }\end{array}$ \\
\hline Atenção & $\begin{array}{l}\text { Ação de fixar a mente sobre alguma coisa, ponderação, cuidado, } \\
\text { meditação, aplicação. } \\
\text { É o processo de se concentrar seletivamente em determinados } \\
\text { elementos do estímulo, tipicamente aqueles considerados mais } \\
\text { importantes. }\end{array}$ \\
\hline Pensamento & $\begin{array}{l}\text { Conjunto de processos pelos quais o ser humano mediante o contato } \\
\text { com a realidade material e social, elabora conceitos, estabelece } \\
\text { relações e adquire novos conhecimentos; } \\
\text { Maneira de pensar ou julgar, ponto de vista, opinião, conjunto de idéias } \\
\text { próprias de alguém ou de um grupo. }\end{array}$ \\
\hline Linguagem & $\begin{array}{l}\text { Sistema de signos orais ou escritos que usam os membros de uma } \\
\text { comunidade para a comunicação; } \\
\text { Faculdade humana que permite comunicar idéias ou sentimentos. }\end{array}$ \\
\hline Criatividade & $\begin{array}{l}\text { Criar só é possível quando o cérebro detém uma grandiosa e alargada } \\
\text { variedade de conhecimentos e informações. Essas associações } \\
\text { permitirão alcançar as idéias e conceitos novos, de uma forma única e } \\
\text { original. O processo criativo pode ser classificado em: } \\
\text { Criatividade individual: é a forma criativa expressa por um indivíduo } \\
\text { Criatividade coletiva ou de grupo ou criatividade em equipe: forma } \\
\text { criativa expressa por uma organização, equipe ou grupo. Surge } \\
\text { geralmente da interação de um grupo com o seu exterior ou de } \\
\text { interações dentro do próprio grupo e tem como objetivo principal } \\
\text { otimizar ou criar produtos, serviços e processos.Na organização } \\
\text { moderna a "criatividade em equipe" é o caminho mais curto e mais } \\
\text { rápido para modernização e atualização. }\end{array}$ \\
\hline
\end{tabular}


Capítulo 7: RESULTADOS E DISCUSSÃO 


\section{1 -ANÁLISE dOS RESULTADOS OBTIDOS NA REVISÃo BIBLIOGRÁFICA REALIZADA NA METODOLOGIA DE ESTUDO}

\subsection{1- Categorias 1 e 2 : Anos e Locais de Publicação dos jogos}

Analisamos os jogos de acordo com as duas primeiras categorias iniciais que foram ano e local de publicação. Essas categorias são subdivididas em duas subcategorias cada uma. A primeira foi subdividida em períodos entre 1929-1999 e 2000-2009 (últimos 10 anos), já a segunda categoria foi subdividida em nacionais e internacionais, as mesmas foram correlacionadas. Internacionalmente entre o período de 1929-1999 uma pesquisa de fundamental importância foi realizada por Jeanne B. Russel (1999) apud Soares (2004), em extensa revisão bibliográfica, a autora descreve artigos que utilizam jogos para ensinar Química, publicados em periódicos de renome, tais como Journal of Chemical Education, The Chemical Educator, entre outros. Esta revisão apresenta jogos relacionados aos conceitos das mais diversas áreas da química, desde conceitos gerais (elementos, estruturas atômicas, nomenclatura, fórmulas, equações, reações e também, há um jogo de tabuleiro para se discutir tabela periódica), como os que envolvem Química Inorgânica (ácidos e bases, soluções), também aparecem jogos cuja temática desenvolvida é voltada para Química Orgânica e Instrumentação.

O jogo mais antigo descrito pela autora data do ano de 1935, Chemical Lotto (Caldwell, 1935) em um total de 71 artigos, que se distribuem entre apenas 14 autores. Porém foi encontrado um jogo que foi publicado no ano de 1929. Esse jogo é denominado de Chemical Bank (Howard, 1929) que trata da temática química orgânica. Por esse motivo iniciaremos nossa perspectiva histórica a partir do ano de publicação deste jogo, pois o mesmo é a publicação mais antiga relativa a esse tema.

Há também relatos sobre jogos que usam mais uma vez a temática de química orgânica como The Game of name (Goldsmith. 1971), Xtal-line (Alsobrook, 1973), Elosis (Ziegle, 1974). Chemantics e Balancing Games (Schimtt, 1976a ; 1976b) dois jogos que trabalham com o tema reações químicas. Jogos computacionais como 0 
Computer Game in Chemistry (Smith, 1977), The electron game (Wiseman, 1978) e Kinects (Harsch, 1984) também aparecem na revisão de Russel (1999).

O uso de selos e estampas é usado por Schreck \& Lang (1985). Os mesmos descrevem o uso de selos com desenhos relacionados à Química Orgânica e a algumas descobertas científicas.

Utchinson \& Willerton (1985) utilizaram camisetas e coleções de estampas de produtos para ensinar conceitos relativos à presença e importância da química no cotidiano do estudante. Banks (1996) apresenta um dominó com assuntos de Química Orgânica. Helser (1999) descreveu o uso de palavras cruzadas com nomes de compostos químicos, entre outros.

A partir dos anos 2000-2001 foi observada uma considerável ampliação na publicação de diversos jogos em periódicos internacionais. Uma espécie de banco imobiliário, no qual se vendem e se compram diversas substâncias químicas, foi discutido por Deavor (2001). Além disso, Dkeidek (2003) descreve um jogo de ligar os pontos, dependente da relação de raios entre os elementos químicos representados por cada ponto, no qual o resultado final pode ser uma figura humana ou a de um animal. O uso do tradicional jogo de bingo para ensinar nomenclatura de compostos inorgânicos é apresentado por Crute (2000).

Waddel \& Rybolt (1996, 1999, 2001, 2002, 2003, 2004, 2005, 2006, 2007 entre outros) descreveram uma série de aventuras químicas da dupla Sherlock Holmes e Watson. Os artigos relatam histórias de mistério envolvendo conceitos químicos e, ao final de cada história, o leitor é convidado a resolver o crime ou o mistério relatado. Na página seguinte, os autores disponibilizam a resposta para que o leitor possa conferir sua resolução. Essa série trabalha nos alunos diversos conceitos e habilidades necessárias às práticas docentes atuais, facilitando assim 0 desenvolvimento dos educandos a partir de métodos diferenciados, ou seja, atividades lúdicas que irão propiciar o fechamento da lacuna no processo de ensino e aprendizagem deixado por outros métodos educacionais.

Outro estudo bibliográfico de fundamental importância a respeito de jogos de regras voltados para o ensino de ciências foi o de Moreira (2006; 2008). Ele analisou dez artigos publicados em periódicos internacionais, encontrados em revistas on-line (The American Biology Teacher), entre os quais pode-se citar: STENCEL, J. \& 
Barkoff, A. (1993 ) Cherif, A. H. \& Somervill, C. H.(1995 e 1998), Hudson, M. (2003) , Wyn, M. A. \& Steigink, S. J. (2000), Chinnicl, J. P.; Yue, J. W. \& TOREes, K. M. (2004), Cohen, D.; Ben-Zvi, R.; Hofstein, A. \& Rahamimoff, R. (2004), Stavroulakis, A. M. ( 2005 ), Marx, J. G.; Honeycutt K. A.; Clayton, S. R. \& Moreno, N. P.(2006), SEIPELt, R. L. (2006).

Estes jogos apresentados no trabalho desse autor foram observados para uma categorização inicial. Conclui-se que segundo a primeira categoria (Ano de publicação) $30 \%$ são classificados no grupo de publicações mais antigas (últimos 70 anos) e $70 \%$ no grupo dos mais recentes, ou seja, nos últimos dez anos. Em relação à segunda categoria podemos considerar todos os artigos analisados como sendo internacionais. A terceira categoria pode ser comparada à análise realizada pelo autor através de uma intervenção crítica comparativa de acordo com o nível de interação entre os alunos e a aprendizagem desenvolvida pelos respectivos jogos.

Em nível nacional, no mesmo trabalho, Moreira (2006) descreve a publicação de nove trabalhos nos anais do V ENPEC (Encontro Nacional de Pesquisa e Ensino de Ciências), sendo quatro comunicações orais e cinco painéis que enfocavam jogos ou atividades lúdicas no ensino de Ciências. (Nardi, 2005)

Nacionalmente começaram a aparecer publicações com essa temática e que nos últimos anos começaram a se destacar em congressos e periódicos nacionais. Existem pesquisas recentes específicas do uso de jogos no ensino de química publicados em congressos nos anos de 2009 e 2010. Atualmente existem quatro grupos formados no Brasil que se destacam quando se referem a essa temática tão interessante. No ano de 2009 o grupo da Prof. Dra. Maria Celina Piazza Recena existente na UEMS publicou um trabalho apresentado no Encontro Centro Oeste de Debates em Ensino de Química. O trabalho citado analisava as publicações de jogos em química nas Reuniões Anuais da SBQ (Freitas, D. S.; Marcelino, L. V. e Recena, M. C. P., 2009). Já no ano de 2010, outro grupo de destaque dessa temática denominado de LEQUAL (Laboratório de Educação Química e Atividades Lúdicas do IQ - UFG) liderados pelo Prof. Dr. Márlon Herbert Flora Barbosa Soares, publicou um artigo completo com uma investigação realizada em seis edições do Encontro Nacional de Ensino de Química, entre os anos de 1996 a 2008, ou seja, do VIII ao XIV. A pesquisa foi realizada a partir dos livros de resumo desses encontros. Foram pesquisados trabalhos contendo palavras-chaves como jogos, jogos pedagógicos, 
jogos em química, atividades lúdicas e jogos didáticos. A seguir foram delimitados parâmetros a serem observados.

Existem mais dois grupos que remetem essa temática em suas linhas de pesquisa, estando localizado o terceiro na UEMS, liderados pelos professores doutores Noé de Oliveira, Edemar Benedetti e Antonio Rogério Fiorucci e o último em São Paulo, localizado no IQ da USP, denominado de GALPEQ (Grupo de Atividades Lúdicas e Pesquisa em Ensino de Química) e orientado pela Prof ${ }^{\underline{a}}$ Dr $^{\text {a }}$ Daisy de Brito Rezende. Este último se preocupou em ampliar a análise dos dois primeiros grupos, analisando também em nível nacional os livros de atas do ENPEC (Encontro Nacional de Pesquisa em Ensino de Ciências) dos últimos 10 anos. Em nossas pesquisas observou-se que seria de relevante significância se ampliássemos a análise para o intervalo de 1929-2009, ou seja, os últimos 80 anos e preocupou-se com publicações internacionais nos últimos 10 anos também.

Ao se analisar o estudo bibliográfico realizado nos anos de 2007 até 2010 foram obtidos os dados apresentados na tabela 7.1 e no gráfico apresentado na figura 7.1. Todos os dados foram categorizados e comparados à nacionalidade das publicações. Pode-se observar na tabela 7.1 houve um aumento significativo nas publicações de jogos, principalmente no Brasil nos últimos dez anos (2000- 2009).

Tabela 7.1: Categorias 1 e 2 ( ano de publicação e nacionalidade)

\begin{tabular}{lll}
\hline Periódicos Analisados & $1929-1999$ & $2000-2009$ \\
\hline Internacionais & 93 & 154 \\
Nacionais & 5 & 296 \\
\hline
\end{tabular}

Os jogos mais antigos publicados no Brasil foram encontrados na Revista Química Nova. Um baralho químico foi publicado por Magalhães (1978) e Nicodem (1982) publicou o Biriba da Ressonância. Ambos usam a Química orgânica como temática. 


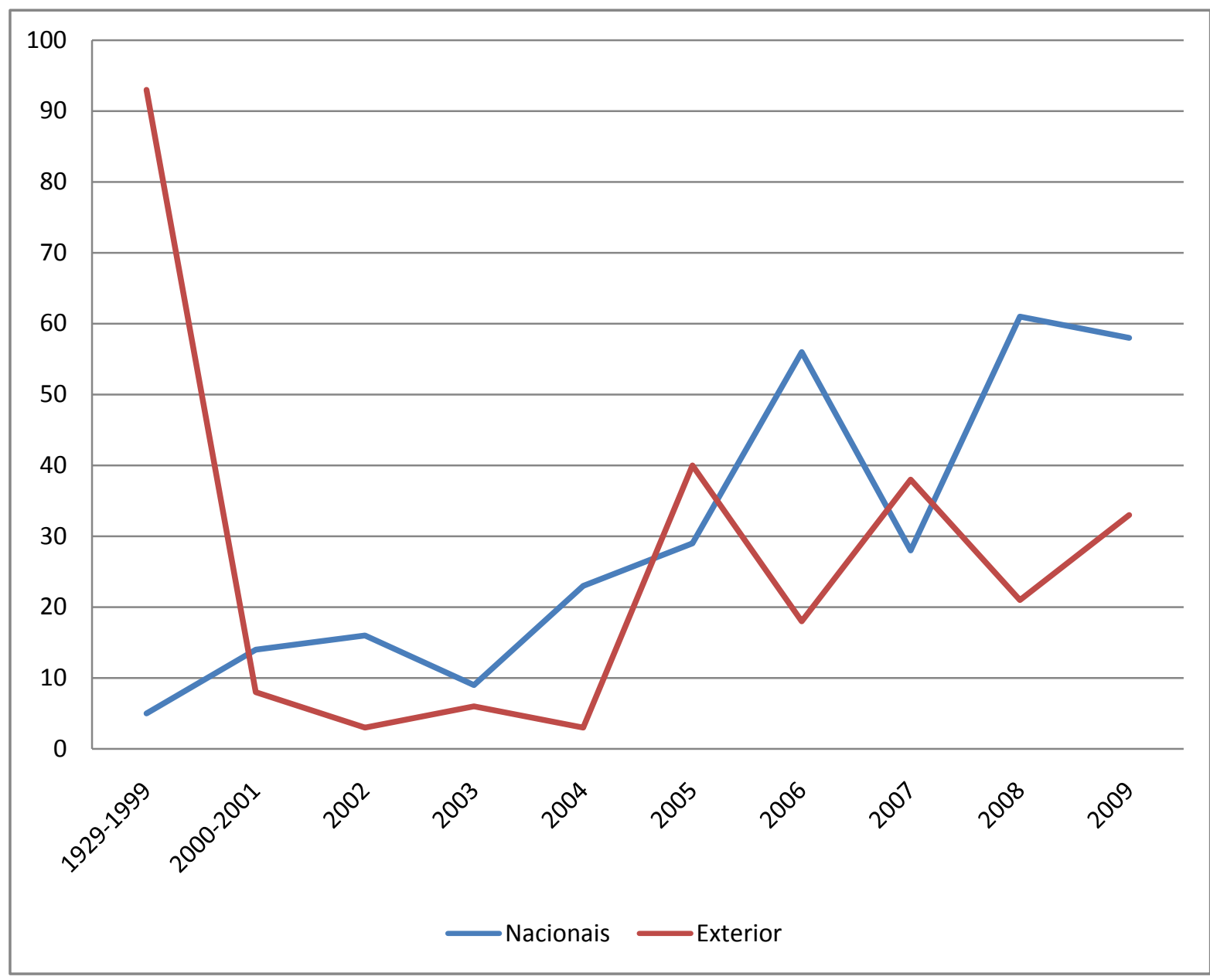

Figura 7.1- Gráfico Comparativo das nacionalidades e anos de publicação dos jogos

Os trabalhos publicados nacionalmente, em sua grande maioria foram publicados efetivamente nos últimos anos, envolvendo assuntos variados, tais como: tabela periódica, compostos orgânicos e inorgânicos, história da química, materiais de laboratório, equilíbrio químico, termoquímica, estrutura atômica, estudo dos gases, química e meio ambiente, reações químicas e solubilidade. Estes trabalhos possuem maior relevância a partir do ano de 2000 , tabela 7.2 , pois são poucos os que são publicados anteriores a essa data.

No gráfico apresentado na figura 7.1 mostra-se a análise detalhada do período de 1929-1999 (70 anos) e de 2000-2009 (últimos 10 anos). Neste último apresenta-se a evolução das publicações de cada ano, ressaltando os aumentos consideráveis das publicações a partir do ano de 2004 a nível nacional. (Tabela 7.2) 
Tabela 7.2: Publicações Nacionais e Internacionais em periódicos nos últimos 10 anos

\begin{tabular}{lcc}
\hline Anos de Publicação & Publicações Nacionais & Publicações Internacionais \\
\hline $2000-2001$ & 14 & 8 \\
\hline 2002 & 16 & 3 \\
\hline 2003 & 9 & 6 \\
\hline 2004 & 22 & 3 \\
\hline 2005 & 29 & 40 \\
\hline 2006 & 56 & 18 \\
\hline 2007 & 28 & 38 \\
\hline 2008 & 61 & 21 \\
\hline 2009 & 58 & 17 \\
\hline
\end{tabular}

$\mathrm{Na}$ tabela 7.2 pode-se observar a evolução da quantidade de publicações no Brasil principalmente nos anos de 2006, 2008 e 2009, pois nesses anos os Nacionais ultrapassam a quantidades de publicações em relação aos periódicos internacionais.

Os tipos de jogos apresentados em nível nacional são os mais diversos possíveis, desde softwares educativos, como o Carbópolis (Eichler, 2000); o Urânio 235 e a Cidade do Átomo (Eichler, 2005) até jogos mais comuns como Dominós (Passos e Santana, 2004), Bingos (Santana, 2006), Jogo da Memória (Santana, 2005), QuebraCabeça (Santana, 2005), Batalha Naval Periódica (Santana, 2006) ,RPG : Role Playing Game (Cavalcanti e Soares, 2009), Autódromos (Santana e Rezende, 2007 e 2008), Ludo Químico (Soares, 2004) Júris Químicos (Oliveira e Soares, 2005; Moreira 2008), Palavras Cruzadas (Filho, Fiorucci, Benedetti e Craveiro, 2009),Passa ou Repassa Químico e Caça ao Tesouro (Santana, 2008; 2009). 
Tabela 7.3: Publicações Nacionais em congressos nos últimos 10 anos

\begin{tabular}{llll}
\hline Congressos Nacionais & ENEQ & RASBQ & ENPEC \\
\hline $1998-1999$ & 3 & 2 & 14 \\
2000 & 8 & 2 & - \\
2001 & - & - & 12 \\
2002 & 14 & 3 & - \\
2003 & - & 3 & 9 \\
2004 & 28 & 2 & - \\
2005 & - & 7 & 16 \\
2006 & 47 & 9 & - \\
2007 & - & 14 & 21 \\
2008 & 33 & 12 & - \\
2009 & - & 9 & 29 \\
\hline
\end{tabular}

\subsection{2- NíveIS DE COGNIÇÃO DAS ATIVIDADES LÚDICAS}

Cognição é a capacidade ou processo de adquirir e assimilar percepções e conhecimentos. Ao analisar os jogos observou-se que muitos dos mesmos, principalmente a nível internacional possuíam um fator em comum, as habilidades cognitivas trabalhadas no jogo eram elementares. Entende-se por habilidade elementar a memorização, reprodução, repetição, entre outros, ou seja, aplicação direta do conhecimento voltada para o ensino tradicional, o que Freire (1996) chama de ensino bancário, como se o conhecimento fosse depositado nos alunos sem que os mesmos utilizem sua criticidade, criatividade e dialogicidade.

Os aspectos cognitivos podem ser relacionados com as Funções Psicológicas (Vygotsky, 2005; 2007). Essas funções se apresentam de duas formas distintas, as elementares e as superiores. (Figuras 7.2 e 7.3 ) 
Segundo Vygotsky (1998), a característica central das funções elementares ou FPE é que elas são total e diretamente determinadas pela estimulação procedente do meio ambiente. Para as funções superiores ou FPS, a característica central é a estimulação autogerada, isto é, a criação e o uso de estímulos artificiais que se transformam em causas imediatas do comportamento.

Cerca de $80 \%$ dos jogos que aparecem em publicações internacionais remetem a estes aspectos cognitivos elementares, enquanto que em periódicos nacionais esses valores se enquadram entre 60 - 70 \% dependendo assim do local de publicação como é mostrado na tabela 7.4.

Em nível nacional, percebe-se que a percentagem de jogos que desenvolvem habilidades mais elevadas é mais significativa se comparado aos periódicos internacionais (tabela 7.4). Não sendo o adequado ainda, pois o ensino de Química encontra-se em constante mudança, porém é notória a diferença entre os objetivos dos jogos.

Tabela 7.4: Categoria 3 ( nível de cognição)

\begin{tabular}{lll}
\hline Periódicos Analisados & $\begin{array}{l}\text { Aspectos Cognitivos } \\
\text { Elementares }\end{array}$ & $\begin{array}{l}\text { Aspectos Cognitivos } \\
\text { Elevados }\end{array}$ \\
\hline $\begin{array}{l}\text { Periódicos } \\
\text { Internacionais }\end{array}$ & $80 \%$ & $20 \%$ \\
\hline Periódicos Nacionais & $60 \%$ & $40 \%$ \\
\hline Anais de Congressos & $70 \%$ & $30 \%$ \\
\hline Internet & $70 \%$ & $30 \%$ \\
\hline
\end{tabular}

Consideramos também como aspectos cognitivos elevados ou superiores o trabalho em grupo, criatividade, liberdade, liderança, capacidade de interagir entre os colegas e expor seus pensamentos, socialização, trocam de experiências, entre outros. (Melo, 2005; Cabrera e Salvi, 2005) 


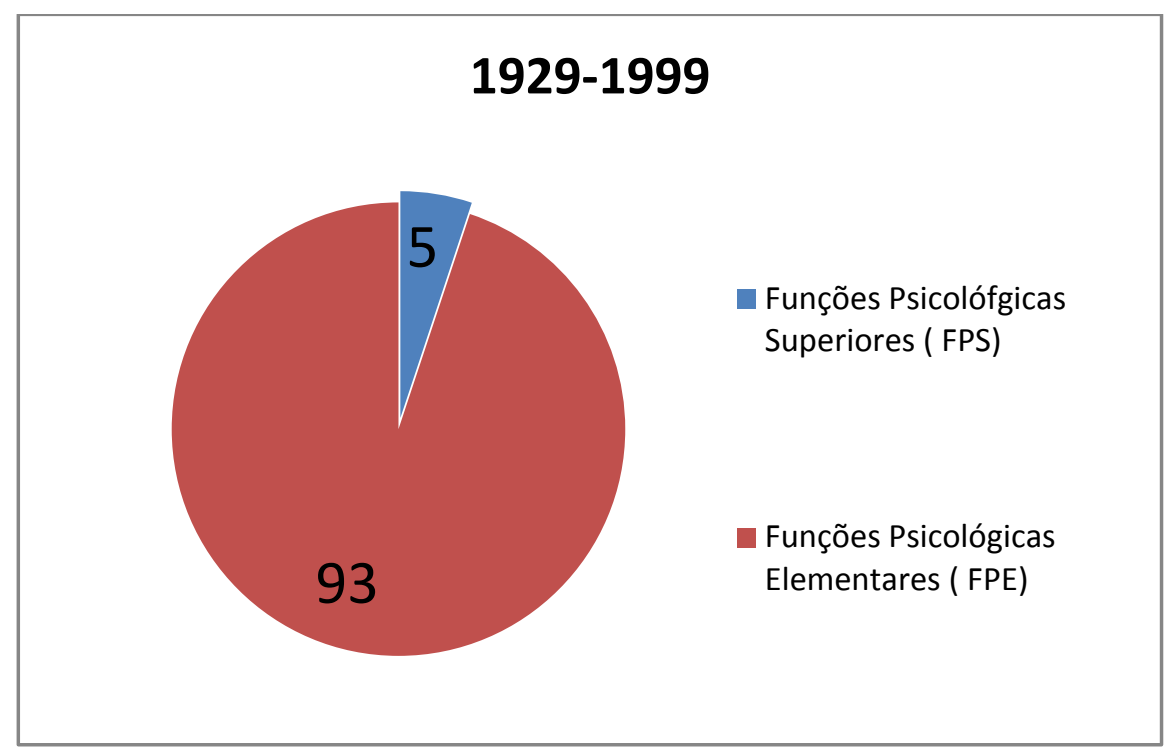

Figura 7.2: Relação das Funções Psicológicas com os jogos publicados entre 1929-1999.

Vygotsky (2007) estudou as FPS, enquanto funcionamento psicológico tipicamente humano, diferenciando-as das funções psicológicas elementares, enquanto processos de origem biológica. É a transformação de funções elementares em superiores que Vygotsky (2007) geralmente tinha em mente quando falava da forma como a natureza do desenvolvimento se modifica

Segundo os estudos de Coll (1996) essas funções supõem o uso de intermediários externos, nesse caso o uso de atividades lúdicas - que são denominados por ele como instrumentos psicológicos, implicando um processo de mediação, utilizando certas estratégias, ou por meio de determinados instrumentos psicológicos que tratam de modificar a nós mesmos, alterando diretamente nossa mente e nosso funcionamento psíquico.

As funções superiores são transformações qualitativas que ocorrem na interrelação entre os fatores externos e os internos resultando da apropriação e a internalização de instrumentos e signos em um contexto de interação.

A emoção, a imaginação, a percepção, a atenção, a linguagem e a memória formam o conjunto das funções psicológicas superiores destacadas neste trabalho. Observamos de acordo com os gráficos apresentados nas figuras 7.2 e 7.3 que nos anos de 1929-1999 as funções que mais apareciam no desenvolvimento através do jogo eram as elementares, 93 jogos pesquisados nesse período retratam essas funções. Em relação às funções psicológicas superiores apenas cinco jogos 
apresentam seu desenvolvimento. Porém com o passar do tempo foram observados um aumento dos jogos que favorecem o desenvolvimento das FPS. No gráfico da figura 7.3 observa-se que a quantidade de jogos foi ampliada para 64, já os que trabalham as FPS chegam a 352.

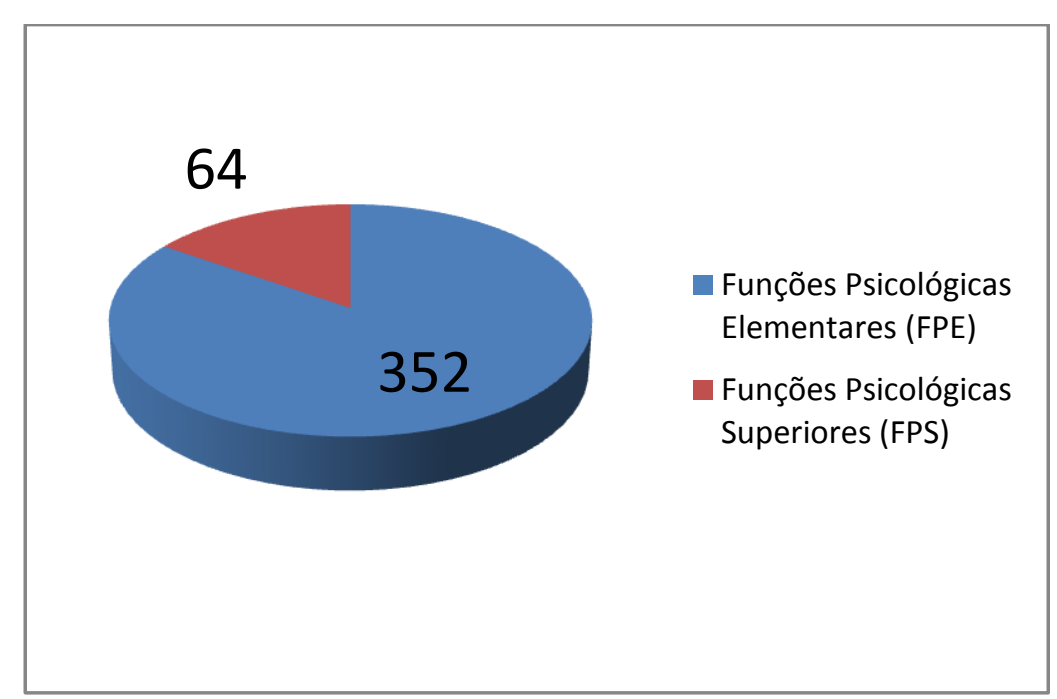

Figura 7.3: Relação das Funções Psicológicas com os jogos publicados entre 2000-2009.

Ao compararmos os dois gráficos constatou-se um grande aumento do desenvolvimento das FPS, pois nos anos de 1929-1999 esses jogos eram de aproximadamente 5\%, já no período posterior 2000-2009 essa porcentagem passou para $15,3 \%$ ou seja, um aumento de $10 \%$, um valor considerável se comparado com a diferença dos intervalos dos anos pesquisados 1929-1999 (70 anos) e 2000-2009 (10 anos). 


\section{2 -ANálise dAS Avaliacões Diagnósticas (INICIAIS, CONTINUADAS E}

\section{FINAIS)}

\subsection{1- Análise Diagnóstica Inicial (Pré-Teste)}

A primeira etapa da construção dos dados consistiu na análise das respostas dos alunos frente aos instrumentos diagnósticos e categorização das mesmas (Bardin, 2000). Um dos instrumentos diagnósticos foi aplicado antes de se iniciarem as etapas do jogo, sendo denominado de análise diagnóstica inicial (anexo A). A avaliação continuada foi realizada durante a aplicação e também está presente nas filmagens, pois faz parte do estudo dirigido usado na metodologia. (Anexos $B, C, D e$ E). Após aplicação de todas as etapas do jogo, realizou-se a análise diagnóstica final (Anexo F).

Os resultados obtidos a partir da análise das respostas do pré-teste aplicado (Anexo $A$ ) aparecem em forma de percentagem para cada uma das nove turmas (Tabelas 7.5 a 7.8), agrupados por categoria em função das palavras indutoras. Nesse caso, as palavras indutoras utilizadas na análise diagnóstica inicial foram: Alquimia, Alquimistas, Pedra Filosofal e Química.

$\mathrm{Na}$ análise da primeira palavra indutora (Alquimia), enquadramos as respostas dos alunos em quatro categorias: Transformação, Pré-Química, Magia e Motivações (Tabela 7.5). Essas categorias foram construídas a partir das respostas dos alunos, exemplificadas nos Quadros 7.1 a 7.4.

As respostas que aparecem nos Quadros 7.1 a 7.4 foram extraídas dos Prétestes, sendo usados o número da caderneta e a turma ( $\mathbf{A}$ até $\mathbf{I})$ de que o estudante fazia parte para identificar a resposta. Assim, o significado de uma identificação como Estudante $2 A$ é que o aluno pertence à turma $\mathbf{A}(2006)$, na qual a seqüência numérica segue a ordem alfabética na turma; a codificação foi utilizada em todas as nove turmas.

Os gráficos apresentados na Figura 7.4 sintetizam os resultados apresentados na Tabela 7.5 para a palavra indutora Alquimia. Observa-se, pela análise desses gráficos, que, para quatro das turmas $(\mathbf{C}, \mathbf{F}, \mathbf{H}, \mathbf{I})$, a categoria mais significativa, ou 
seja, que obteve maior porcentagem (variando de $40 \%$ a 53,5\%) foi Magia e Misticismo. A categoria menos citada foi Motivação (porcentagens variando no intervalo de $3,6 \%$ a $22,2 \%$ ); nesse caso, os alunos achavam que a Alquimia tinha como objetivo a imortalidade (Quadro 7.4).

Tabela 7.5: Resultados em porcentagem (\%) para Alquimia, em função das turmas.

\begin{tabular}{|c|c|c|c|c|c|c|c|c|c|c|}
\hline Categorias & Evocações & A & B & C & D & E & $\mathbf{F}$ & $\mathbf{G}$ & $\mathbf{H}$ & $\mathbf{I}$ \\
\hline Transformação & Transformação & 27,5 & 20,0 & 20,0 & 25,9 & 25,0 & 19,2 & 15,4 & 10,0 & 7,2 \\
\hline Pré- Química & $\begin{array}{l}\text { Ciência que originou a } \\
\text { Química }\end{array}$ & 30,0 & 24,0 & 26,7 & 40,8 & 28,6 & 15,4 & 30,8 & 30,0 & 35,7 \\
\hline Magia & $\begin{array}{l}\text { Magia, Misticismo; } \\
\text { Feitiços e Bruxaria }\end{array}$ & 35,0 & 36,0 & 40,0 & 22,2 & 35,7 & 50,0 & 30,8 & 50,0 & 53,5 \\
\hline Motivações & Imortalidade & 7,5 & 20,0 & 13,3 & 22,2 & 10,7 & 15,4 & 19,2 & 10,0 & 3,6 \\
\hline
\end{tabular}

\section{TRANSFORMAÇ̃̃̃O}

Uma vez assisti um desenho que dizia que alquimia é uma transformação de vários materiais.

Estudante 2-H

É quando você mistura vários elementos formando um novo.

Estudante 23- $\mathrm{H}$

\section{Quadro 7.1: Alquimia e Transformações}

\section{Pré-Química}

Estudo bastante erudito e peculiar, a química antiga! É o estudo que as pessoas faziam para descobrirem coisas novas.

Estudante 1-H

É o estudo da Química antiga!

Estudante 17-H

\section{Quadro 7.2: Alquimia e Pré-Química}

MAGIA

É uma ciência criada por volta da ldade Média que misturava arte e magia. 


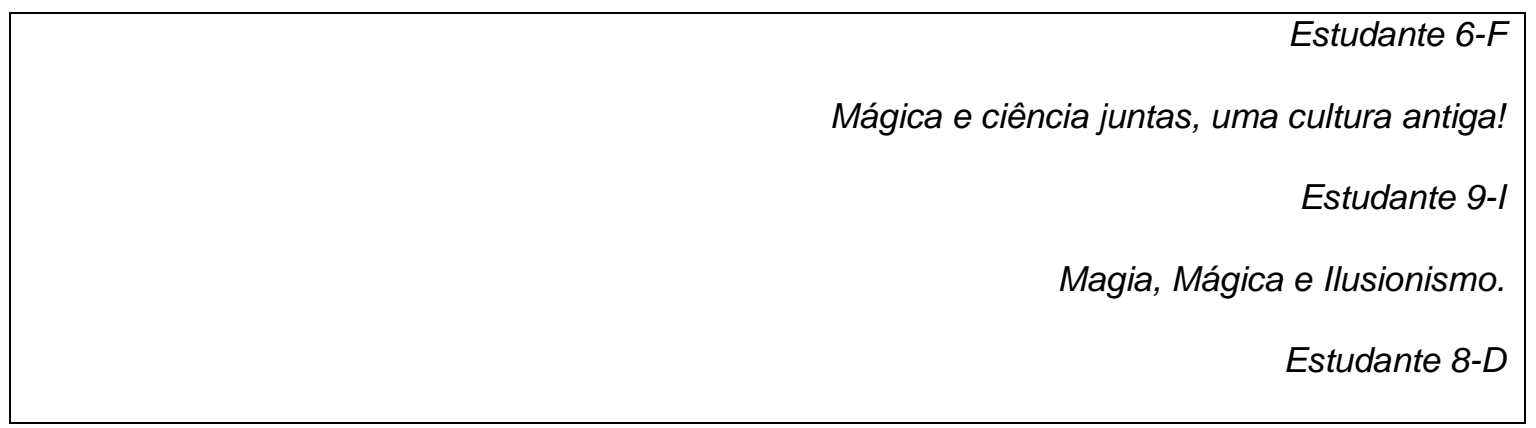

Quadro 7.3: Alquimia e Magia

\section{MOTIVAÇÕES}

É uma mistura de arte e magia, teve seu auge na Idade Média com o objetivo de garantir uma longa vida.

Estudante 12-G

A alquimia tenta descobrir coisas improváveis de existir como a pedra filosofal e o elixir da longa vida.

Estudante 7-F

\section{Quadro 7.4: Alquimia e Motivações}

Estes resultados podem ser explicados devido à inexistência de indivíduos desvinculados de seu meio cultural, logo, as respostas apresentadas pelos alunos nas análises diagnósticas iniciais devem-se à influência do universo cultural dos mesmos nessa faixa etária, em que o tema magia está relacionado com Alquimia. Essa temática encontra-se muito presente em jogos, filmes, desenhos, revistas e livros, facilitando a associação desses temas pelos educandos (Quadro 7.1). A questão da imortalidade é menos marcante nessas mídias.

Podemos nos embasar nas idéias de Vygotsky para explicar os fatores observados na análise das respostas apresentadas na Tabela 7.5 e Figura 7.4. Na concepção desse autor, todo e qualquer ser humano apresenta-se inserido em um determinado ambiente cultural, que faz parte essencialmente de sua própria constituição enquanto pessoa. Torna-se impossível pensar nos seres humanos de forma isolada, sem nenhum contato com um grupo cultural, pois esses grupos serão fornecedores de instrumentos e signos que possibilitarão o desenvolvimento das atividades humanas. 


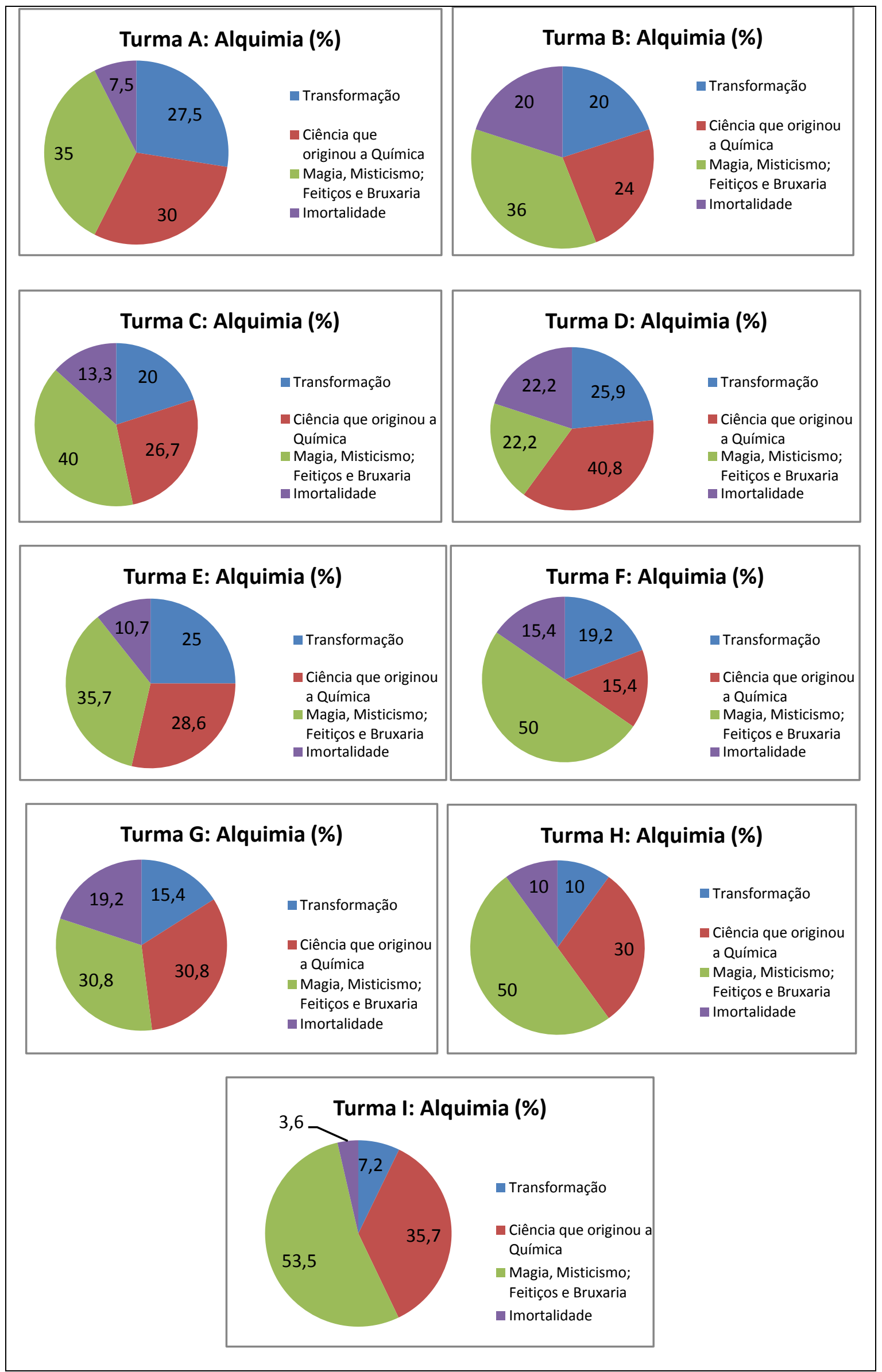

Figura 7.4: Gráficos de 9 turmas com os resultados da Palavra Alquimia 
Nessa situação, Oliveira (1999) complementa que o aprendizado envolto nesse processo é fundamental para a construção do ser humano. O desenvolvimento do educando, nesse caso, será baseado no aprendizado que, sempre envolve a interferência, direta ou indireta, de outros indivíduos e a reconstrução pessoal da experiência e dos significados.

As categorias Pré-Química e Transformações aparecem nas respostas dos alunos em porcentagens bem próximas, a depender das turmas observadas (Figura 7.4). Ocorre uma variação de $15 \%$ a $40 \%$ em relação à Pré-Química e de $7 \%$ a $28 \%$ em relação à categoria que indica Transformação.

No caso das turmas A, B, E e $\mathbf{G}$ observa-se que a idéia de que a Alquimia seja uma Pré-Química é tão significativa quanto a associação à Magia enquanto, na turma D, a idéia da Alquimia ser uma Pré-Química prevalece claramente. As categorias Transformação e Pré-Química em cinco das seis primeiras turmas (exceto para D) aparecem com porcentagens próximas.

A análise dos gráficos sugere que os erros conceituais e epistemológicos apresentados nos instrumentos culturais apresentados no capítulo 2 e presentes na vivência dos alunos, influenciam diretamente suas concepções, como mostram suas respostas.

Em relação à segunda palavra indutora (Alquimistas), observa-se o aparecimento de seis (06) categorias, algumas das quais divididas em sub-categorias (Tabela 7.6). São elas: Transformação, Pré-Química, Magia, Experimentação, Saberes e Motivações (Quadros 7.5 a 7.10).

Mais uma vez é observado que as respostas dos alunos se concentram em torno de duas categorias principais. Nesse caso, a primeira foi Pré-Química (Quadro 7.6), presente nas respostas de oito das nove turmas pesquisadas, sendo a turma $\mathbf{E}$ a única em que não aparecem respostas classificáveis nessa categoria. A outra categoria que merece destaque é Magia (Quadro 7.7), presente nas nove turmas, oscilando em um intervalo de $12 \%$ a $43 \%$. 
Tabela 7.6: Resultados em porcentagem (\%) para Alquimistas, em função das turmas.

\begin{tabular}{|c|c|c|c|c|c|c|c|c|c|c|}
\hline Categorias & $\begin{array}{c}\text { Sub- } \\
\text { categorias }\end{array}$ & A & B & C & D & E & $\mathbf{F}$ & $\mathbf{G}$ & $\mathbf{H}$ & I \\
\hline Transformação & & 10,0 & -- & -- & -- & -- & -- & -- & 10,0 & - \\
\hline Pré-Química & & 12,5 & 20,0 & 16,7 & 18,5 & -- & 46,1 & 38,5 & 30,0 & 10,7 \\
\hline Magia & & 27,5 & 32,0 & 40,0 & 11,1 & 25,0 & 30,8 & 42,3 & 40,0 & 35,7 \\
\hline Experimentação & & 7,5 & 8,0 & 10,0 & 7,4 & -- & 15,4 & 11,6 & 10,0 & 14,3 \\
\hline \multirow[t]{3}{*}{ Saberes } & Metalurgia & 7,5 & 4,0 & -- & 7,4 & -- & -- & -- & -- & - \\
\hline & Matéria-prima & 2,5 & 4,0 & 3,3 & 3,7 & -- & -- & -- & -- & - \\
\hline & Transmutação & 10,0 & 4,0 & & 10,7 & 3,9 & -- & -- & -- & 3,6 \\
\hline \multirow[t]{4}{*}{ Motivações } & Imortalidade & -- & -- & -- & -- & -- & -- & -- & -- & - \\
\hline & $\begin{array}{l}\text { Pedra } \\
\text { Filosofal }\end{array}$ & 7,5 & 20,0 & 6,7 & 14,8 & 32,1 & - & - & 10,0 & 7,1 \\
\hline & $\begin{array}{c}\text { Mudança da } \\
\text { História }\end{array}$ & 2,5 & -- & -- & -- & -- & -- & -- & -- & - \\
\hline & $\begin{array}{c}\text { Praticantes da } \\
\text { Alquimia }\end{array}$ & 12,5 & 8,0 & 23,4 & 37,1 & 25,0 & -- & 7,7 & -- & 28,6 \\
\hline
\end{tabular}

Mais duas categorias merecem destaque em nossa análise. A primeira é Motivações (Quadro 7.10), ressaltando a relevância da subcategoria Praticantes da Alquimia, que foi citada por sete turmas. A segunda é Experimentação (Quadro 7.8), que mais uma vez não foi citada por apenas uma das nove turmas, nesse caso, a turma E.

Esses resultados podem ser explicados devido aos meios e mídias culturais que apresentam a palavra Alquimistas de diversas formas. Muitos dos alunos associaram essa palavra aos personagens que eles usam para jogar RPG, que são os alquimistas, magos, feiticeiros e bruxos. Esse é um dos fatores que contribuem para uma porcentagem tão significativa da categoria Magia. Outro fator de grande 
influência nesse resultado é o uso do filme Harry Potter ${ }^{1}$, tão divulgado pela mídia, apresentando um alquimista chamado Nicolas Flamel que, no filme, era amigo do diretor da escola de magia. Outro meio cultural que influenciou não apenas a categoria magia, mas a categoria motivações foi à apresentação de uma minissérie, intitulada "O Pequeno Alquimista", em um canal aberto de televisão ${ }^{2}$, no ano de 2005. Existe, também, um livro intitulado "O Alquimista $^{3}$, de um autor internacionalmente conhecido, que pode ter colaborado para essas porcentagens apresentadas na Tabela 7.6.

TRANSFORMAÇÃo E AlQUIMISTAS

Os alquimistas eram pessoas que estudavam muito para descobrirem novas coisas. Estudante 8-F

Quadro 7.5: Transcrição de respostas categorizadas como Transformação.

PRÉ- Química e Alquimistas

Eram estudiosos da Química Antiga.

Estudante 19- G

Estudavam processos químicos usados antigamente.

Estudante 23-B

São pessoas que trabalham com produtos químicos a fim de interesse científicos.

Estudante 22-G

Quadro 7.6: Transcrição de respostas categorizadas como Pré-Química.

MAgia e Alquimistas

Eram bruxos, tanto que muitos foram queimados na fogueira na época da Inquisição.

Estudante 7-A

Bruxos, Feiticeiros, Magos.

Estudante 21-C

1 O filme Harry Potter e a Pedra Filosofal é um filme dos gêneros aventura, fantasia e mistério dirigido por Chris Columbus e lançado no ano de 2001 pela Warner Bros Studios. O filme é baseado na primeira obra da saga literária Harry Potter, criada pela escritora J.K. Rowling. O filme é o primeiro da série de adaptações cinematográficas da saga, e foi escrito por Steve Kloves e produzido por David Heyman.

2 O Pequeno Alquimista foi uma microssérie exibida pela emissora de televisão Rede Globo em quatro capítulos, durante quatro semanas, no período de 26/12/04 a 16/01/05.

Esta minissérie foi baseada nos livros $O$ pequeno alquimista e $O$ pequeno alquimista e o elixir da longa vida, de Márcio Trigo. O programa especial dedicado ao público infanto-juvenil era escrito por Mariana Mesquita, Cláudio Lobato e Thereza Falcão, com redação final de Mariana Mesquita. A direção era de Ulysses Cruz, a direção geral de Márcio Trigo e a direção de Núcleo de Carlos Manga.

3 O Alquimista é um best-seller do escritor brasileiro Paulo Coelho.

O livro foi traduzido para mais de 56 línguas, tendo vendido mais de 65 milhões de cópias em todo mundo. 
Quadro 7.7: Transcrição de respostas categorizadas como Magia.

EXPERIMENTAÇÃO E ALQUIMISTAS

Eles estudavam fenômenos através de experimentos.

Estudante 19-E

São pessoas que trabalham com substâncias através de experimentos

Estudante 27-H

Quadro 7.8: Transcrição de respostas categorizadas como Experimentação.

SABERES E ALQUIMISTAS

Eles trabalhavam com a alquimia e com metais.

Estudante 11-D

Metalurgia

Dominavam a metalurgia e técnicas de extração de metais.

Estudante 5-G

Buscavam matérias-primas para realizar seus estudos.

Estudante 24-A

MATÉRIA - PRIMA

Descobriam e estudavam a matéria-prima.

Estudante 32-A

Os alquimistas faziam a transmutação dos metais.

Estudante 16-I

Transmutação

São Cientistas que usam elementos para tentar criar outros.

Estudante 3-E

Quadro 7.9: Transcrição de respostas categorizadas como Saberes

Motivações E AlQuimistas

Queriam a Imortalidade.

Estudante $7 \mathrm{H}$

IMORTALIDADE

Pessoas que tinham como objetivo de vida a imortalidade.

Queriam viver por muito tempo, alguns tinham mais de 200 anos, isso

eu li na internet.

Estudante 25-B

Buscavam a pedra filosofal que nem no filme 1 de Harry Potter.

Estudante 4-D

PEDRA

FilosofaL

MUdANÇA DA

HISTÓRIA
Queriam muito a pedra filosofal que era uma substância muito importante naquela época.

Estudante 1-C

Eles estudavam e trabalhavam com o objetivo de mudar a história.

Estudante 5-A 


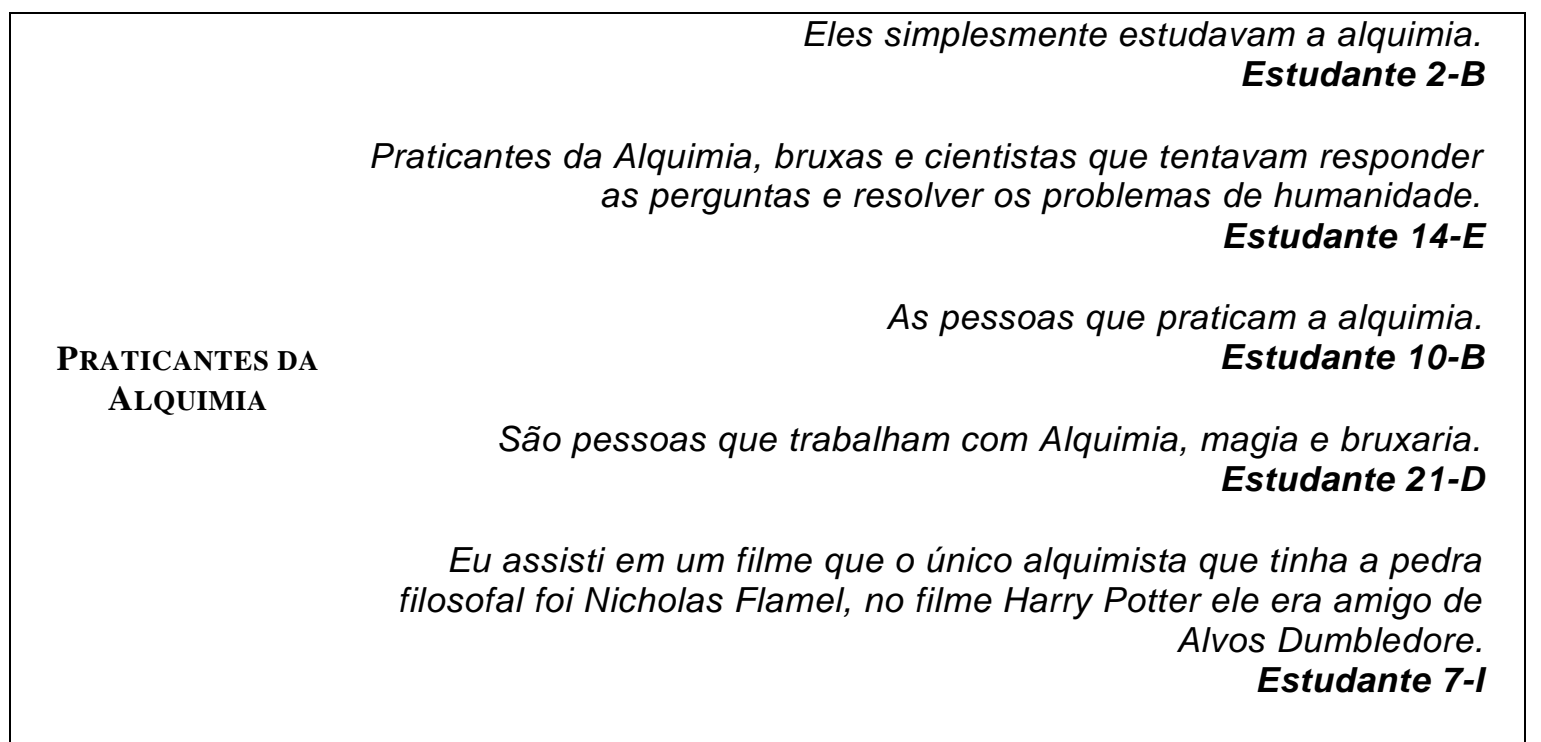

Quadro 7.10: Transcrição de respostas categorizadas como Motivações e respectivas subcategorias.

A análise das respostas para a terceira palavra indutora, Pedra Filosofal, levou à construção de quatro categorias (Transformação, Magia, Motivações e Conceitualização), estando as duas últimas divididas em sub-categorias (Tabela 7.7; Quadros 7.11 a 7.14). No caso da categoria Magia, a referência aos filmes de Harry Potter foi explícita e significativa (vide nota da Tabela 7.7), reforçando a idéia de que há artefatos culturais que têm influência relevante no aprendizado dos alunos, que não se restringe ao limite das atividades escolares. Esse fator confirma a necessidade de se problematizarem conceitos que possam interferir na aprendizagem de novos conteúdos, como é o caso de Alquimia e dos termos relacionados a essa temática, que, caso não tenham seu significado expresso e discutido pelos alunos, podem contribuir para dificultar a compreensão das diferenças epistemológicas entre Química e Alquimia.

Transformação e a Pedra Filosofal

É uma pedra que transforma ferro em Ouro.

Estudante 17I

Ela transforma os objetos.

Estudante 1B

Quadro 7.11: Transcrição de respostas categorizadas como transformação. 
Tabela 7.7: Resultados em porcentagem (\%) da Palavra 3 (Pedra Filosofal).

\begin{tabular}{|c|c|c|c|c|c|c|c|c|c|c|}
\hline Categorias & $\begin{array}{l}\text { Sub- } \\
\text { categorias }\end{array}$ & A & B & C & D & E & $\mathbf{F}$ & $\mathbf{G}$ & $\mathbf{H}$ & $\mathbf{I}$ \\
\hline Transformação & & 12,5 & -- & 10,0 & 18,5 & 28,6 & -- & -- & 10,0 & 10,7 \\
\hline Magia & & 20,0 & 28,0 & 23,4 & 11,1 & 10,7 & 34,7 & 19,2 & 30,0 & 25,0 \\
\hline \multirow{2}{*}{ Motivações } & Imortalidade $^{\mathrm{a}}$ & 52,5 & 36,0 & 40,0 & 40,7 & 28,6 & 27,0 & 27,0 & 30,0 & 25,0 \\
\hline & $\begin{array}{l}\text { Transmutação } \\
\text { e Imortalidade }\end{array}$ & 10,0 & 24,0 & 16,7 & 26,0 & 21,4 & 30,8 & 27,0 & 20,0 & 25,0 \\
\hline \multirow{2}{*}{ Conceitualização } & $\begin{array}{l}\text { Essência da } \\
\text { vida }\end{array}$ & 2,5 & -- & 3,4 & -- & -- & 7,7 & 23,1 & -- & -- \\
\hline & $\begin{array}{l}\text { Elemento } \\
\text { Simbólico }\end{array}$ & 2,5 & 12,0 & 6,7 & -- & -- & -- & 3,8 & 10,0 & 14,3 \\
\hline \multicolumn{2}{|c|}{$\begin{array}{l}\text { a. \% devida, ao Filme Harry Potter, } \\
\text { conforme as explicações dos alunos: }\end{array}$} & 42,5 & 32,0 & 30,0 & -- & -- & 27,0 & 27,0 & 30,0 & 25,0 \\
\hline
\end{tabular}

\section{MAgia e a Pedra Filosofal}

Pedra Mágica que tem o poder de deixar a pessoa que a possui curada de toda e qualquer doença.

Estudante 19- G

Algo que os Alquimistas usavam para fazer coisas extraordinárias.

Estudante 5- F

É uma pedra com poderes que Pikachú usava no filme Pokémon para enfrentar e derrotar os seus rivais.

Estudante 28- $F$

Quadro 7.12: Transcrição de respostas categorizadas como Magia.

\section{MOTIVAÇões E A PEDRa Filosofal}

TRANSMUTAÇÃO E IMORTALIDADE

IMORTALIDADE
A Coisa mais cobiçada pelos alquimistas, o que Ihes daria vida eterna e o poder de transformar outros metais em ouro.

Estudante 3G

É uma pedra que é considerada o elixir da longa vida, tornando a pessoa imortal, dando sabedoria e inteligência a quem possui.

Estudante $29 \mathrm{H}$

Quem a achasse poderia viver o quanto quisesse.

Estudante 22A 


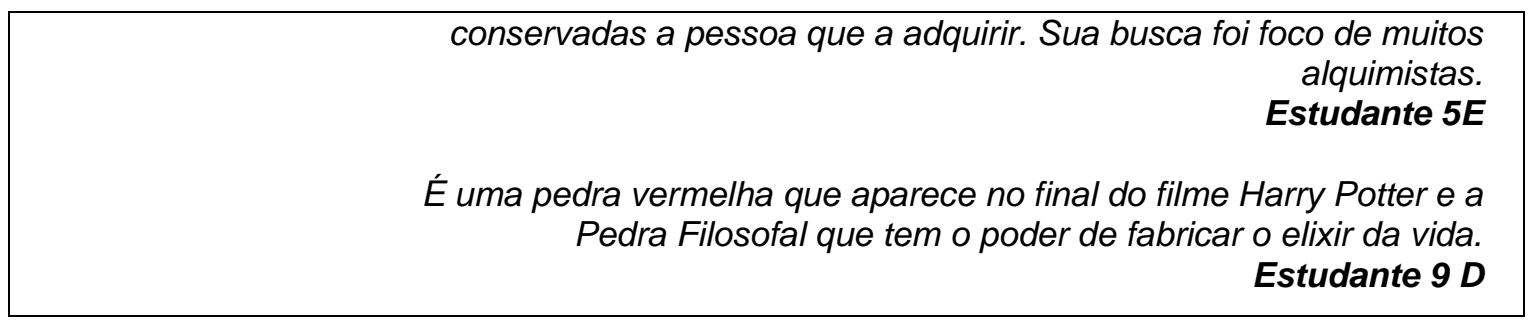

Quadro 7.13: Transcrição de respostas categorizadas como Motivações.

\section{CONCEITUalização e a Pedra Filosofal}

ESSÊNCIA DA VIDA

É a pedra que busca a verdadeira essência da vida humana.

Estudante 2F

ELEMENTO Simbólico

Na verdade é um elemento simbólico que representa a pureza de espírito.

Estudante 11H

Quadro 7.14: Transcrição de respostas categorizadas como Conceitualização.

Observamos que, para as três primeiras palavras indutoras, as categorias Transformações, Motivações e Magia estiveram presentes em todos os momentos da análise. Porém, não aparecem em todas as turmas, principalmente ao se observar as porcentagens relativas às evocações devidas à palavra três (Pedra Filosofal). Essas diferenças são explicáveis, pois, pessoas que vivem em uma mesma época histórica podem apresentar vários processos de desenvolvimento, em conseqüência de diferenças em suas atividades ou nas condições de vida e existência.

Assim, esse resultado pode ser explicado considerando-se os artefatos culturais utilizados por alunos de diferentes grupos e períodos, pois o universo cultural em que eles estão envolvidos não é, necessariamente, idêntico. Esse fator é importante para as características de cada turma. Há distinção entre as mesmas, pois são constituídas por pessoas diversas em épocas diferentes, com pensamentos e ações distintas, já que a pesquisa teve início no ano de 2006 e foi concluída no ano de 2010, ou seja, um intervalo de cinco anos, ocorrendo mudanças culturais e sociais nesse período.

Da análise da quarta palavra motivadora, Química, foram construídas três categorias (Transformação, Pré-Química e Conceitualização; Quadros 7.15 a 7.17), e mais algumas subcategorias (Tabela 7.8). 
Observamos a partir da Tabela 7.8, que as respostas dos alunos puderam ser categorizadas, em sua maioria, em Transformações (Quadro 7.15). Essa categoria é a prevalente em todas as turmas, exceto $\mathbf{G}$, com valores entre $25 \%$ e $78 \%$. Em relação à Pré-Química (Quadro 7.16), nas seis turmas houve respostas que puderam ser agrupadas nessa categoria, com porcentagens representativas (de 7 a $28 \%$ ).

Tabela 7.8: Resultados em porcentagem (\%) da Palavra 4 Química

\begin{tabular}{|c|c|c|c|c|c|c|c|c|c|c|}
\hline Categorias & Sub-categorias & A & B & C & D & $\mathbf{E}$ & $\mathbf{F}$ & $\mathbf{G}$ & $\mathbf{H}$ & $\mathbf{I}$ \\
\hline Transformação & & 52,5 & 32,0 & 46,8 & 77,8 & 46,4 & 26,9 & 30,8 & 33,3 & 25,0 \\
\hline Pré- Química & & 15,0 & 28,0 & 26,7 & - & 7,1 & 19,2 & 27,0 & - & - \\
\hline \multirow[t]{6}{*}{ Conceitualização } & Meio ambiente & 5,0 & 4,0 & - & - & - & - & - & 16,6 & 21,4 \\
\hline & $\begin{array}{l}\text { Tudo que está } \\
\text { presente no dia-a- } \\
\text { dia }\end{array}$ & 5,0 & 8,0 & 6,7 & 3,7 & 21,4 & 3,8 & 3,8 & 13,4 & 10,7 \\
\hline & $\begin{array}{l}\text { Pode ser usado } \\
\text { para o bem e o mal }\end{array}$ & 2,5 & - & - & 3,7 & - & - & - & 13,4 & 10,8 \\
\hline & $\begin{array}{l}\text { Mistura de } \\
\text { elementos e } \\
\text { substâncias }\end{array}$ & 12,5 & 24,0 & 13,3 & - & 25,0 & 23,0 & 34,6 & 3.3 & 7,1 \\
\hline & Poções & - & - & - & 3,7 & - & - & - & - & - \\
\hline & $\begin{array}{l}\text { Fenômenos } \\
\text { Químicos }\end{array}$ & 7,5 & 4,0 & 16,7 & 11,1 & - & 27,0 & 3,8 & 20,0 & 25,0 \\
\hline
\end{tabular}

Quanto à Conceitualização (Quadro 7.17), foram construídas seis subcategorias que envolvem meio ambiente, cotidiano, benefícios e malefícios da ciência, elementos e substâncias, poções e, por fim, fenômenos químicos.

Ao analisar as subcategorias apresentadas, observa-se que meio ambiente (4 até $22 \%$ ) e benefícios e malefícios da ciência (2,5 a 13,5\%) estão presentes em apenas 4 turmas, enquanto poções está representada em apenas uma turma, correspondendo a $4 \%$ das respostas. Já as demais estavam presentes em 
praticamente todas as turmas, com exceção da turma $\mathbf{D}$, no que se refere à subcategoria elementos e substâncias e à turma E, na qual a subcategoria fenômenos químicos não aparece.

\section{QUímiCA E TRANSFORMAÇÃo}

Estuda os fenômenos químicos, vários tipos de fórmulas e substâncias como a água, o álcool e os tipos de misturas, estudando também as transformações e fenômenos que ocorrem na natureza.

Estudante 1-F

A Química é a ciência que estuda os fenômenos que transformam o estado da matéria.

Estudante 3-A

Estuda fenômenos que transformam uma matéria em outra.

Estudante 12-C

Quadro 7.15: Transcrição de respostas categorizadas como Transformação.

Pré- QuímiCa E Química

A Química já existia antes, é uma evolução da alquimia.

Estudante 5-C

Uma deu origem à outra.

Estudante 8-C

Quadro 7.16: Transcrição de respostas categorizadas como Pré-Química.

Conceitualização

A Química estuda o meio ambiente como um todo.

Estudante 2I

Ciência que estuda a natureza e as transformações que nela ocorrem.

Estudante 3H

MEIO AMBIENTE

Ciência que estuda os fenômenos químicos que ocorre no meio ambiente.

Estudante 10A

É o estudo de fenômenos químicos naturais.

Estudante 12B

ESTÁ PRESENTE

NO DIA-A-DIA
A Química é o estudo das substâncias ao nosso redor, de onde elas vêm, quais são as vantagens e desvantagens destas substâncias. 


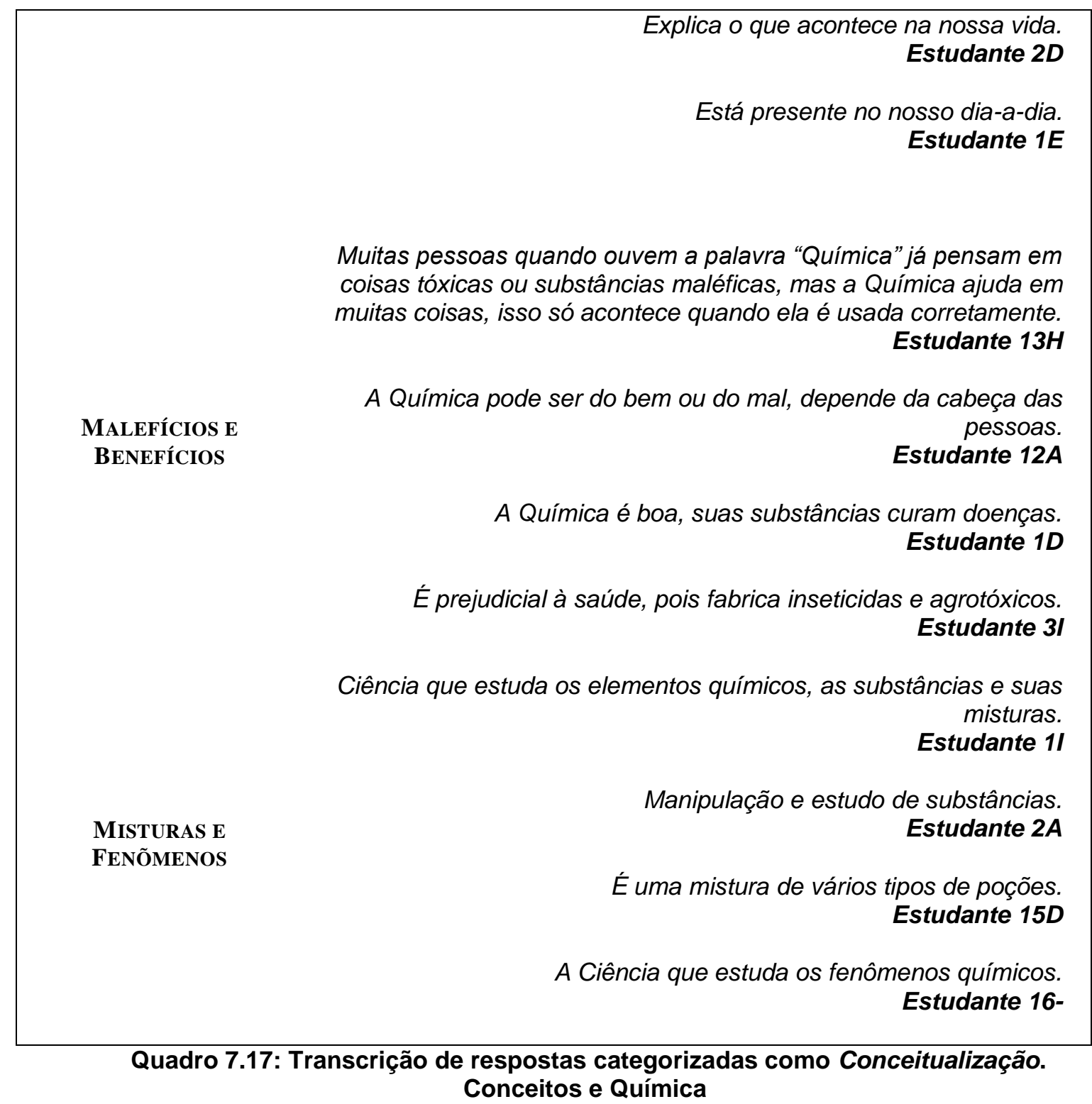

Este conjunto de resultados evidencia que as concepções dos alunos são influenciadas pelo meio em que se encontram. As concepções dos alunos devem-se à internalização de situações e signos determinados pelos meios culturais e pelos recursos tecnológicos disponíveis. A apropriação dessas situações e signos será transformada em instrumentos de significação, de pensamento e ação, facilitando uma nova compreensão do indivíduo quanto à sua relação com o contexto.

É a partir de sua experiência com o mundo objetivo e do contato com as formas culturalmente determinadas de organização, e com os signos fornecidos pela cultura, que os alunos vão construindo seu sistema de signos e, conseqüentemente, interiorizando suas concepções. A sociedade em que o indivíduo está inserido é 
determinante do conteúdo e a motivação na vida do ser humano, pois todas as atividades dominantes aparecem como elementos da cultura.

\subsection{2- Análise Diagnóstica Continuada}

Nessa atividade de discussão, a professora refletiu sobre as orientações a serem feitas a seus alunos, dentro do contexto pedagógico adotado. As etapas do jogo, que culminariam no Autódromo Alquímico, foram assumidas e explicitadas, pois se, por um lado, os alunos em grande parte dependem da mediadora para o contato com atividades promotoras de desenvolvimento, nesse caso atividades lúdicas, por outro, a maneira como é feita a seleção de atividades e o tipo de mediação oferecida deve ser cuidadosa. As atividades não devem estar aquém ou além das necessidades e possibilidades dos alunos que as desenvolvem.

Nesta seção, será mostrado como a mediação realizada pelo processo do Jogo contribui para o desenvolvimento das FPS, explicitando-se as diferentes funções com base em Vygotsky (2000; 2005; 2007).

\subsubsection{1 - EMOÇÃO}

As falas mostradas nos Quadros 7.18 e 7.19 referem-se a diferentes momentos do jogo. No Quadro 7.18, estão apresentados excertos que se referem à impressão individual dos alunos quanto ao filme que haviam acabado de assistir. No segundo caso, apresenta-se um episódio de discussão entre os alunos. Como se pode observar pelas falas transcriadas nesses quadros (7.18 e 7.19), quando os alunos estão emocionalmente envolvidos na ação, o processo de ensino e aprendizagem é facilitado, aumentando principalmente a motivação a respeito do entendimento da temática.

Ah, professora, eu adoro os filmes do Harry Potter e não tinha idéia de que poderíamos aprender com eles, ao invés de apenas assistir. Agora sim, eu entendi melhor as coisas que aparecem lá. 
\begin{tabular}{|lr|}
\hline Eu sempre escutava e lia sobre esse negócio de alquimia, magia e feiticeiros, pois \\
eu jogo muito RPG e esses são alguns personagens que gosto de jogar e não sabia \\
que poderíamos entender essas coisas, eu achava que isso não fazia parte da história \\
verdadeira, pensava que era só faz-de-conta.
\end{tabular}

Quadro 7.18: Transcriação das falas de alguns alunos sobre o filme e jogos.

Estes excertos mostram que muitos alunos começaram a se envolver na atividade, pois se identificaram muito com o tema alquimia. Como foi comentado na justificativa desta pesquisa, esse tema faz parte do universo cultural deles, estando presente em filmes, livros, desenhos, jogos, vídeos-game, internet, revistas e até em livros. Esse fator pode ser explicado de acordo Elkonin (1998), pois em seus estudos ele relata que a base do jogo é social devido precisamente a sua natureza e origem, ou seja, a que o jogo se desenvolve a partir das condições de vida do aluno na sociedade.

O episódio extraído da filmagem, apresentado no Quadro 7.19, também exemplifica o envolvimento emocional com o processo. Nele, observa-se a importância da interação social e da mediação para a aprendizagem, percebendo-se as interações dos alunos com os colegas, com o professor e com o jogo.

\footnotetext{
GRUPO 2

TURMA H

ANO 2010

MOMENTO: Logo após a apresentação do filme

PARTE da TRANSCRIAÇÃo:

Aluno A: Ei, olha aí viu, assim fica bem legal de entender!

Aluno B: Assim como?

Aluno C: Oxente, com o filme que a gente assistiu na aula passada.

Aluno $A$ : $E$ isso que eu tô falando!

Aluno D: Eu também acho, pois, no ano passado, não tinha essas coisas e eu não entendi bem as coisas, apesar de eu estar repetindo o ano acho bem melhor assim!

Aluno A: Mas, vamos aqui fazer o que a professora pediu!

Aluno B: Verdade, vai lá, assim eu vou entender melhor!
} 
Aluno A: Primeiro, o que vocês perceberam ao assistir o filme?

Aluno $C$ : Eu vi sobre o objetivo da pedra filosofal!

Aluno A: Claro né, olha só o nome do filme: Harry Potter e a Pedra Filosofal... Não é isso que ela quer?

Aluno B: Mas ele não falou por mal, paciência, ôxe!

Aluno D: Eu entendi que, no filme o alquimista, Nicolas Flamel, ele tinha a Pedra...

Aluno A: Sim, claro, a Pedra Filosofal...

Aluno $B$ : $E$ isso é verdade?

Aluno C: Claro que não, ué. Até parece!

Aluno A: Eu sei que esse alquimista aí, Flamel, ele é famoso, passou até na minissérie da globo um dia desses, acho que ano passado.

Aluno D: Sei, eu assisti. Era o pequeno alquimista né?

Aluno A: Hum, isso mesmo...

Aluno B: Eu também assisti!

Aluno C: Mas, então, qual era o objetivo mesmo?

Aluno D: Imortalidade!

Aluno B: Não era só isso era?

Aluno A: Claro que não!

Aluno B: Então, tinha mais coisas? O que mais?

Aluno A: No filme fala também de transmutação!

Aluno C: Ah! Esse eu sei, porque no jogo de RPG isso aí aparece!

Aluno D: Transmutação? Não seria Transformação?

Aluno $C$ : É transmutação mesmo!

Aluno A: Tem a ver com metais!

Aluno B: Com Ouro!

Aluno C: Ah! Tá! Tô entendendo tudo agora!

Aluno A: É quando os alquimistas tentavam transformar todo metal em ouro!

Aluno B: Assim fica fácil!

Aluno C: Mas, isso existiu mesmo?

Aluno D: Acho que sim, tem nos livros também falando sobre isso!

Aluno B: Mas no nosso livro não fala só disso, né?

Aluno D: Claro que não, tem mais coisa!

Aluno A: Então a gente coloca como, aqui no estudo?

Aluno B: Fala que nem no filme!

Aluno C: É; também acho!

Aluno D: Mas isso tá certo? Esse filme?

Aluno B: Nem sei, mas a gente pode perguntar!

Aluno C: Coloca na lista de dúvidas de perguntas!

Aluno A: Concordo.

Aluno D: Tá bom, e quem vai escrever isso ai? 
Aluno B: Eu posso escrever.

Aluno A: Você escreve e a gente fala!

Aluno B: Tá, pode ser.

Quadro 7.19: Transcriação de um episódio da filmagem do grupo 2 (turma H).

Ao desenvolver em sala de aula um trabalho com jogos, deve-se observar a existência de duas dimensões, a cognitiva e a emocional (afetiva). As duas dimensões devem ser trabalhadas em equilíbrio, pois assim a influência do professor no processo é facilitada.

Os aspectos emocionais estão diretamente ligados ao desenvolvimento afetivo do educando e à sua relação com a construção do conhecimento, como mostrado nos Quadros 7.18 e 7.19. Esse envolvimento favorece o desenvolvimento dos aspectos cognitivos (Vygotsky, 2007; Elkonin, 2000).

A análise destes quadros (7.18 e 7.19) mostra que a emoção foi uma das primeiras FPS a se manifestar nesses grupos de alunos. Como qualquer forma de pensamento, de comportamento e ação é permeada pela emoção, esse resultado é importante porque esse aspecto facilita o processo de desenvolvimento cognitivo. Esses dados mostram que a temática tem a capacidade de envolver os alunos.

Contudo, é importante ressaltar que a emoção não domina o comportamento dos alunos (Quadros 7.18 e 7.19), pois nota-se que vão se estabelecendo relações entre a emoção e outras funções psíquicas. Com a utilização da linguagem, como mostrado na transcriação das filmagens apresentadas (Quadros 7.18 e 7.19), a emoção é mediada e sua expressão é modificada (Vygotsky, 2007).

Categorias observadas na análise diagnóstica inicial podem ser identificadas no episódio mostrado, como seria de se supor nesse momento de início de discussão (Quadro 7.19). As categorias que mais se revelam nesses trechos são Transformação, Saberes, Motivações e Conceitualização.

Ainda ao ser analisado o episódio apresentado no Quadro 7.19 podemos ver que a dinâmica interativa facilita a elaboração e o entendimento de conhecimentos, que se produzem nas interações sociais e com o meio. O contato com o outro, as diversas formas de pensar, agir e entender dos alunos durante o jogo, constantemente marcado por tensão, são fatores primordiais no processo. 
Por esses motivos, é necessário deixar os alunos à vontade para assim facilitar 0 processo criativo e imaginativo existente no diálogo entre os alunos do grupo e entre eles e componentes dos outros grupos.

\subsubsection{2- PercepçÃo}

Ao longo do desenvolvimento humano, principalmente através da internalização da linguagem e dos conceitos e significados culturalmente desenvolvidos, a percepção, de acordo com Oliveira (1999), deixa de ser apenas uma relação direta entre o indivíduo e o meio, passando a ser mediada por conteúdos culturais. Esses conteúdos culturais são representados pelos filmes, livros, jogos e vídeo games apresentados no Capítulo 2 e influenciam no diálogo e nas interpretações dos alunos, como apresentado no Quadro 7.20.

Os alunos se apropriam desses conteúdos e efetuam relações sociais concretas fazendo a transposição da sua realidade cultural com o desenvolvimento da atividade lúdica. Para Elkonin (1998), não existe atividade desconexa com a realidade, já que praticamente todos se baseiam em atividades anteriormente desenvolvidas, tendo inicialmente um caráter utilitário, para depois receber novas influências sociais e se constituir em uma atividade lúdica.

O entendimento das atividades lúdicas, neste contexto, só pode ser realizado se levarmos em conta o complexo processo educacional a que cada um dos alunos está submetido. Entretanto, os educandos precisam começar a intervir/agir nesse mundo, fato que só pode ser realizado pela apropriação cultural de diversos elementos constituintes da sociedade, dentre eles, os diversos meios culturais citados anteriormente.

Novamente, é importante ressaltar como a interação entre os alunos também provoca intervenções no seu desenvolvimento. Observamos, durante as filmagens, que os grupos de educandos sempre se apresentam de forma heterogênea quanto ao conhecimento. Percebemos que, quando um aluno possui maior facilidade de assimilação de determinado assunto, ele contribui para o desenvolvimento dos outros colegas de turma. Assim, como o professor, um colega também pode 
funcionar como mediador entre um aluno e outro e entre as ações e significados estabelecidos como relevantes no interior da cultura.

A percepção consiste na apreensão de uma totalidade e sua organização consciente não é uma simples adição de estímulos locais e temporais, o que chega à consciência são configurações globais, dinâmicas e perfeitamente integradas de sensações. Embora as sensações não nos ofereçam em si mesmas, a compreensão do mundo, elas representam os elementos necessários ao conhecimento, sem os quais não existiriam percepções.

Como mostrado no Quadro 7.20, a percepção de mundo dos alunos não se dá em termos de atributos isolados, mas em termos de objetos, eventos e situações definidos pela linguagem e classificados pela cultura. Nesse episódio, observam-se falas classificáveis nas seguintes categorias: Pré-Química, Magia, Transformação, Saberes e Conceitualização.

\section{GRUPO 1 \\ TURMA I \\ ANO 2010}

MOMENTO: Estudo Dirigido

Parte da Transcriação:

Aluno A: Vocês trouxeram o material gente?

Aluno B: Sim, claro!

Aluno C: Nós precisamos de que mesmo para responder?

Aluno A: Do máximo de material possível!

Aluno D: Isso mesmo foi ela (a professora) que disse!

Aluno E: É só que vamos responder com atenção esse troço!

Aluno C: Vamos parar de enrolar e começar, por que a filmadora tá ligada já!

Aluno A: Ai, lá vai então!

Aluno B: Qual a primeira pergunta?

Aluno C: A primeira pergunta sobre alquimia e seus objetivos!

Aluno D: Vocês lembram o que vocês responderam naquele papelzinho antes do fime? Aluno A: Eu respondi em relação ao filme e os livros de Harry Potter mesmo, porque eu tenho todos lá em casa e assisto sempre, então eu falei em relação a Magia, Bruxaria. Aluno B: Eu falei em relação a Bruxaria também, mas eu lembrei dos jogos de RPG, que tem personagens assim sabe, bruxo, magos, feiticeiros e alquimistas.

Aluno D: Eu não falei sobre isso não, eu lembrei que eu li na internet que a alquimia veio antes da química, como se uma fosse o complemento da outra. 
Aluno A: Mesmo? Eu nunca pensei nisso!

Aluno C: Nem eu! Quando eu respondi falei que era em relação à transformação das coisas. E acho que é isso mesmo!

Aluno A: Tem lógica, tudo isso tem lógica!

Aluno B: Então vamos colocar como?

Aluno D: Bota um mistura de tudo!

Aluno A: Pode ser!

Aluno C: Certo, eu escrevo pra vocês e os objetivos a gente vai colocar o que?

Aluno $B$ : $E$ isso ai a gente vai ter que ler o material e pesquisar o objetivo.

Aluno D: No filme era a transmutação ou transformação!

Aluno B: O elixir também!

Aluno C: O elixir dá a imortalidade!

Aluno D: E o resto?

Aluno A: Vamos procurar então!

Quadro 7.20: Transcriação de parte da filmagem do grupo 1, turma I.

\subsubsection{3- ATENÇÃO}

No Quadro 7.21, por exemplo, observa-se que os alunos demonstraram assimilação e capacidade de seleção de informações, como mostrado no episódio transcriado, ressaltando-se que, quando da realização da atividade, havia transcorrido pelo menos uma semana da apresentação do filme. Como se percebe facilmente nas falas dos alunos, eles não haviam esquecido os aspectos fundamentais para a discussão.

Nota-se, ainda, que os alunos mantinham o foco da discussão durante todo 0 episódio, demonstrando 0 papel da FPS denominada atenção para 0 desenvolvimento da atividade, como também se percebe claramente no episódio apresentado no Quadro 7.21, por exemplo.

As falas transcriadas nesse episódio são representam três categorias: Conceitualização, Saberes e Motivações.

\section{GRUPO 1}

TURMA H

ANO 2010

MOMENTO: Estudo Dirigido 


\section{PARTE da TRANSCRIAÇão:}

Aluno A: Tá bom vamos continuar ai o estudo dirigido senão não vai sobrar tempo!

Aluno B: A parte agora é sobre a Pedra Filosofal?

Aluno A:Sim, o que tem ai? Lê pra gente!

Aluno C: Fale sobre a pedra filosofal de acordo com o filme: "Harry Potter e a Pedra Filosofal".

Aluno A: Tá certo, só isso?

Aluno D: Não, tem mais ainda sobre isso!

Aluno C: Você concorda com a função da pedra filosofal descrita no filme? Se sim, exemplifique, se não concorda justifique sua resposta corrigindo a parte discordante.

Aluno E: Então no filme Harry Potter e a Pedra Filosofal eles se referem a pedra quando estão na biblioteca depois do natal!

Aluno A: Como é que aparece?

Aluno B: Aparece bem assim: O Antigo estudo da alquimia preocupava-se com a produção da pedra filosofal, uma substância lendária com poderes fantásticos.

Aluno A: É isso mesmo!

Aluno E: Mas tem mais coisa!

Aluno B: Tem sim!

Aluno C: A outra parte é assim: A pedra pode transformar qualquer metal em ouro puro. Produz também o Elixir da longa vida, que torna quem o bebe imortal

Aluno D: Imortalidade e Ouro eram os objetivos então!

Aluno E: Parece que sim, mas isso no filme né!

Aluno A: E na verdade é como?

Aluno B: Vamos descobrir procurando e lendo!

Aluno C: Claro, fazer do jeito que a professora falou!

Depois de 10 minutos eles retomam a discussão, logo após o estudo e procura nos textos.

Aluno A: Eu achei aqui uma coisa legal!

Aluno B: Foi? Cadê?

Aluno E: Eu também achei uma coisa!

Aluno C: Calma, cada um fala em sua vez!

Aluno A: Eu começo! Aqui diz que a pedra filosofal ela realmente produzia o elixir da longa vida e fazia a transmutação!

Aluno B: Então o filme tá certo?

Aluno E: Eu achei diferente aqui!

Aluno C: Então fala ué!

Aluno E: Aqui no meio fala que é uma simbologia! Não é coisa material e sim espiritual!

Aluno D: Acho essa explicação mais certa!

Aluno A: Ah, não sei! 
Aluno B: Então como resolver esse problema?

Aluno E: Não sei!

Aluno C: È Simples! É só explicar as duas coisas que achamos!

Aluno D: Isso mesmo!

Quadro 7.21: Transcriação de parte da filmagem do grupo 1, turma $H$.

\subsubsection{4- MEMÓRIA}

A relação das FPS com o meio físico e social, mediada pelos instrumentos e signos desenvolvidos no interior da vida social, possibilita ao ser humano criar e transformar seus modos de ação no mundo. Os fragmentos das filmagens representados no Quadro 7.22, mostram que, neste caso, os instrumentos que relacionam o meio físico e social são os filmes, as discussões, o estudo dirigido e, por fim, o jogo trabalhado. Os excertos mostrados no Quadro 7.22 são exemplos de Conceitualização, Experimentação, Saberes, Motivações e Magia.

As diferentes apropriações culturais realizadas pelos alunos estão diretamente relacionadas à estruturação da sociedade e da cultura lúdica e no momento em que o educando adquire essa cultura por meio das relações e artefatos culturais.

Para Elkonin (1998), o conteúdo desenvolvido nos jogos pode ser caracterizado como uma teia de relações sociais, no qual através da transposição de suas significações históricas permite ao aluno uma efetiva entrada no âmbito das diversas aprendizagens sociais, facilitando, portanto, no desenvolvimento de um cidadão crítico.

\footnotetext{
GRUPO 3

TURMA H

ANO 2010

MOMENTO: Após a aplicação do Estudo dirigido

Parte da Transcriação: RelaÇão da MemÓria com instrumentos mediadores.

Aluno A: Temos que elaborar as perguntas para serem usadas nos jogos, agora!

Aluno B: É, cuidado com essas perguntinhas básicas ai!

Aluno C: Mas é fácil, quando a gente escutar alquimia sempre vai relacionar com o filme, com o jogo e as discussões que a gente trabalhou aqui na aula!
} 
Aluno A: Também acho!
Aluno D: É mesmo.
Aluno B: Não só isso!
Aluno C: Tem também o resto, né?
Aluno D: Qual resto?

Aluno A: As outras coisas que a gente sabia antes, o Fullmetal mesmo, aqueles desenhos animados.

Aluno B: Tem os filmes de Pokémon Também!

Aluno C: Muitas coisas gente, RPG, filme, livro, tem até parque na Disney agora, eu li que iam lançar um parque sobre os filmes!

Aluno A: Calma ai! Lembrar da Alquimia por essas coisas não indica que isso tá certinho, né!

Aluno C: Claro que não, lembra da conclusão do nosso estudo, a alquimia não tem a ver com a magia e sim como as pessoas que estavam de fora enxergavam isso!

Aluno B: É na verdade eles eram considerados como bruxos porque a igreja católica não aceitavam os seus estudos, ai criaram uma linguagem com signos!

Aluno A: Mas pense ai, naquela época aparecer um grupo de pessoas que queriam transformar qualquer metal em ouro...

Aluno D: Sem contar também do elixir da vida, que daria a "possível" imortalidade!

Aluno A: Isso que é coisa de louco!

Aluno B: Também pudera alguns serem presos e queimados!

Aluno C: Mas tudo isso foi muito importante, porque eles descobriam coisas importantes usadas até hoje!

Aluno A: Verdade.

Aluno B: O banho-maria é um exemplo disso!

Aluno D: Sem contar a descoberta de várias substancias que foram desenvolvidas por experimentos.

Aluno A: Acho que a gente pode fazer as perguntas em cima dessas coisas ai que falamos!

Aluno B: Eu concordo!

Aluno C: Também!

Aluno D: Então eu vou começar a preparar as fichinhas!

Quadro 7.22: Transcriação de parte da filmagem do grupo 3, turma $\mathrm{H}$.

As funções psicológicas estão inter-relacionadas, isto é, cada função psicológica estabelece relações com as demais funções. Dificilmente desenvolve-se uma função separadamente, pois o funcionamento do psiquismo é integrado em um sistema psicológico. (Vygotsky, 2005) 
Com a apropriação das funções psicológicas superiores, o indivíduo (o adolescente) começa a adquirir maior controle de suas ações e a memória passa a ser uma função do pensamento, ou seja, o indivíduo recorda ou memoriza um conteúdo que ele deseja e o faz por meio de signos auxiliares. Esses conteúdos memorizados são constituídos de elementos abstratos e a memória baseia-se na lógica.

\subsubsection{5- GeneralizaÇÃo E AbStraçÃo}

A generalização e a abstração são duas funções psicológicas muito importantes, principalmente quando a relacionamos ao Ensino de Ciências. Nesse caso específico, relacionado à temática Alquimia e Química, essas FPS proporcionam uma maior compreensão dos conceitos associados a esses temas, atuando no aprimoramento de conceitos gerais e conceitos abstratos.

A observação do excerto apresentado no Quadro 7.23 evidencia que, no processo de abstração não existem conceitos idênticos, pois cada indivíduo presta mais atenção a algumas características, em detrimento de outras, dependendo de sua formação e do universo cultural em que se encontra. Segundo Elkonin (1998) isso ocorre porque o desenvolvimento psíquico produzido pela atividade lúdica está intimamente relacionado com o tipo de apropriação que os alunos realizam em seu cotidiano.

Percebe-se, também, que houve ressignificação dos conceitos-chave trabalhados. Os conceitos identificados nas falas dos alunos podem ser classificados nas categorias Transformação e Conceitualização, mostrando a ressignificação de química.

\section{GRUPO 5}

TURMA I

ANO 2010

MomenTo: Durante o estudo, elaboração de questões

Parte da TranscriaÇão: Generalização e abstração

Aluno A: Nós devemos ficar atentos para entender ao máximo o assunto.

Aluno B: Claro, né. 
Aluno C: Vamos observar os detalhes para começar a fazer as perguntas direito.

Aluno D: Deveríamos começar falando do conceito de Alquimia...

Aluno A: Então, vamos ler as orientações.

Os alunos leram as instruções presentes no estudo dirigido entregue após o filme.

Aluno D: Como eu disse antes, vamos fazer uma sobre a Alquimia primeiro.

Aluno B: Podemos falar sobre os erros que aparecem nos livros.

Aluno A: No filme também.

Aluno D: Então, como fica? Começamos por qual parte? Quero fazer a primeira questão.

Aluno $C$ : Vocês responderam o quê sobre alquimia?

Aluno B: Eu coloquei que era uma coisa antiga, que tinha a ver com a magia.

Aluno $C$ : $E$ você respondeu isso por quê?

Aluno B: Por causa dos filmes, mas agora eu sei que não é isso apenas.

Aluno D: Temos que fazer uma pergunta que todos entendam a resposta, depois essa pergunta vai parar nas nossas mãos e, aí, que vai ser bonito se ninguém souber responder direito.

Aluno C: A gente que vai decidir se a resposta está coerente! Então, atenção!

Aluno D: Todos têm que concordar, ué.

Aluno A: Sim, claro, tá nas regras!

Aluno B: Concordo!

Aluno C: Então tá!

Aluno B: Como eu tava falando, não tem a ver com magia não, mas transformação.

Aluno D: Que tipo de transformação?

Aluno B: Tipo "Mudança".

Aluno D: Alteração das coisas.

Aluno A: Da matéria.

Aluno D: Também, na verdade dos materiais.

Aluno B: Pode ser.

Aluno C: Pode ser não, na verdade é.

Aluno A: Então porque sempre aparece magia nesse meio?

Aluno D: Olha a época menino.

Aluno B: Verdade, a época pode ser a culpada.

Aluno C: Certo! Então, como acontecia?

Aluno B: Imagine o que as pessoas pensariam de uma pessoa que transformava coisas sem saber muito bem o por quê?

Aluno C: Bruxos!

Aluno A: Claro, né, isso não é normal.

Aluno D: Eu também pensaria isso, vocês não?

Aluno B: Se até hoje o povo pensa, imagine só naquela época.

Aluno A: Tempos diferentes, locais diferentes, pensamentos diferentes.

Aluno C: Mas buscavam a pedra filosofal e o elixir da longa vida, não era? 
Aluno A: Teoricamente sim.

Aluno B: Como assim, apenas teoricamente?

Aluno A: Aparece em alguns livros, mas pelo o que tá dando prá ententer tem muito mais coisa nessa história.

Aluno B: Quais coisas?

Aluno D: Agora eu estou entendendo, li aqui na pesquisa que é metáfora.

Aluno C: De qual tipo?

Aluno B: Simbologia.

Aluno D: Eles não queriam apenas riqueza e imortalidade, mas pureza de espírito.

Aluno C: Queria a pureza da alma!

Aluno D: Queriam atingir a perfeição.

Aluno B: Agora, ficou mais fácil de entender.

Aluno D: Verdade!

Aluno A: E a relação com a Química, então, é a mesma questão.

Aluno B: Sim, as transformações das coisas.

Aluno D: Então, qual a diferença?

Aluno C: Os objetivos.

Aluno A: Com Certeza.

Continua ...

Quadro 7.23: Transcriação de parte da filmagem do grupo 5, turma I .

Para que haja formação de conceitos propriamente ditos, é importante o desenvolvimento de conceitos espontâneos, do cotidiano, de base empírica, além do aprimoramento de conceitos científicos, de base abstrata (Vygotsky, 2007). A aquisição desses conceitos envolve, a priori, a cooperação entre o educando e o professor. Reforçando a idéia que parta alunos dessa faixa etária pesquisada, os signos e palavras constituem também um meio de contato social e contribuem para a construção do conceito.

\subsubsection{6- Criatividade}

A interação e envolvimento entre os grupos observados, característica constante no domínio sócio-histórico-cultural, facilitam a criatividade. No Quadro 7.24, que mostra o diálogo de educandos do grupo seis da turma $\mathrm{H}$, além da reelaboração de conceitos, pode-se perceber essa característica. Percebe-se essa reassimilação de 
conceitos pela identificação de um grande número de assertivas classificáveis como Conceitualização.

Elkonin (1998) destaca a criatividade como um processo extremamente importante e profícuo, o qual possibilita aos alunos o desenvolvimento de suas principais ações objetivas na realidade cotidiana, conseqüentemente, a imaginação é colocada em outro patamar, esse importante elemento foi anteriormente desprezado por grande parte dos teóricos sobre o jogo (Piaget, 1971; Chateau, 1954; Caillois, 1990; Brougére, 1998).

\section{GRUPO 6 \\ TURMA H \\ ANO 2010}

MoMENTO: Elaboração das Questões que serão utilizadas posteriormente na aplicação do Autódromo Alquímico.

Parte da Transcriação: Criatividade

Aluno A: Nós temos que preparar as questões para a fase do jogo.

Aluno B: Sim, prestar atenção aos tipos de questões.

Aluno C: Concordo, pois são de três cores, então é melhor fazer antes em uma folha de rascunho prá depois passar a limpo nas fichinhas!

Aluno D: Tudo bem, então podemos colocar nas fichas nossas dúvidas também, né?

Aluno A: Claro né, se colocarmos apenas o que já sabemos não vai ter graça.

Aluno $C$ : Mas, mesmo assim, a gente tem que pesquisar as respostas depois.

Aluno A: Sim, evidente.

Aluno D: Também acho porque depois do jeito que eu não tenho sorte é bem capaz de cair exatamente o que eu não sei.

\section{Risos}

Aluno B: Eu posso passar para as fichas depois, minha letra é bonitinha.

Aluno C: Tá, tá certo. Bora logo com isso.

Aluno A: Começando então pelas vermelhas!

Aluno B: Coloca aquela paradinha de Química antiga como aparece no nosso livro.

Aluno C: Isso mesmo!

Aluno D : Ah sei, aquela parte que aparece : "Alquimia, a precursora da Química"

Aluno B: Essa.

Aluno $C$ : Precursora é o que mesmo?

Aluno A: Que veio antes!

Aluno $D$ : Acho que tem a ver com origem!

Aluno B: Isso mesmo!

Aluno C: Ah, tá! 
Aluno A: Vamos pensar em outra!

Aluno C: Também pode fazer outra falando dos objetivos da Alquimia.

Aluno A: Da Química também.

Aluno $C$ : Dos reais ou dos que aparecem nos filmes?

Aluno A: Não esqueçam dos livros também!

Aluno D: Isso mesmo.

Aluno B: Acho que a gente podia fazer duas diferentes.

Aluno C: Sim, concordo.

Aluno A: Uma com os objetivos reais.

Aluno B: A outra pode ser com as coisas que a gente sabia antes sobre Alquimia.

Aluno C: Certo, mas se a gente vai fazer sobre isso porque a gente não fala também do RPG?

Aluno A: RPG?

Aluno $C$ : Sim, lembra que eu falei dos personagens.

Aluno A: Ah, tá, lembro sim. Feiticeiros, Magos e Alquimistas.

Aluno D: Mas da maneira que você explicou parece que tudo é a mesma coisa.

Aluno B: Verdade.

Aluno C: Sério?

Aluno A: Sim.

Aluno C: Mas, falando sério, eu também pensava isso, porque as fichinhas dos jogos que têm as descrições de cada personagem explicam isso, mas acho que não é bem explicado não, porque pelo que eu tô vendo, a descrição do alquimista não tá tão certinha assim.

Aluno A: Você trouxe as fichinhas aí?

Aluno D: Ah eu também quero ver, fiquei curioso!

Aluno C: Trouxe sim!

Aluno B: Então, lê pra gente!

Aluno C: Tá! Lá vai. "O Alquimista é uma classe de personagens típica de cenários de fantasia medieval. Os "alquimistas" são baseados nos alquimistas históricos, que eram os químicos ou cientistas medievais. Assim, o alquimista, em jogos de RPG, é responsável pela criação de toda sorte de poções e compostos, desde poções de cura, entre outras finalidades, até ácidos, pólvora e outros explosivos. Quando a situação exige que entre em um combate, o alquimista usa seus compostos, jogando ácidos e explosivos em seus inimigos e poções aos seus aliados.

Aluno A: Verdade, ouvindo isso dá até prá pensar em magia.

Aluno D: Até Magia Negra, né!

Aluno C: Eu disse, mas agora eu sei que isso não é bem assim!

Aluno A: Concordo.

Aluno D: Sim, vamos pensar em outra né?

Aluno B: A Sexta pode ser do que tem a ver uma com a outra. A Alquimia e a Química!

Aluno C: É, falar do tipo de ligação entre elas.

Aluno D: A ligação e a diferença né! 
Aluno C : Isso, boa idéia.

Aluno A: Então, já temos mais duas...

Continua...

Quadro 7.24: Transcriação de parte da filmagem do grupo 6 turma $H$.

Segundo os estudos de Vygotsky (2000; 2005; 2007), não se pode definir se um indivíduo é criativo apenas a partir de sua performance ou desempenho individual. As características que compõem o fenômeno da criatividade são dadas pelas experiências de vida de cada sujeito em seu cenário sócio-histórico-cultural. Logo, foi observado o desenvolvimento dessa FPS a partir da interação social apresentada em distintos grupos de estudo.

A criatividade de acordo com Vygotsky (2000) refere-se à atividade individual do sujeito quanto ao produto gerado por ele, sendo influenciada diretamente por fatores e objetos culturais. Esse fenômeno individual denominado criação torna-se fator formador de cultura e poderá ser desenvolvido através do uso de atividades lúdicas, como o jogo descrito nesta pesquisa.

\subsection{3- Análise Diagnóstica Final}

A análise diagnóstica final (pós-teste) foi realizada a partir de um questionário contendo duas questões (Anexo F). Nas respostas dos alunos, observou-se que os mesmos ressignificaram seus conceitos devido ao desaparecimento de algumas categorias se comparadas às análises diagnósticas inicial e continuada.

O primeiro questionamento apresentado foi: Qual o ponto em comum existente entre a Alquimia e a Química?

As categorias observadas a partir das transcrições das respostas apresentam-se na Tabela 7.9 na Figura 7.5, expressos em porcentagens. e nos Quadros 7.25 a 7.28 , em que se exemplificam algumas respostas dos alunos, para as diferentes categorias. 
Tabela 7.9: Ponto em comum entre Alquimia e Química

\begin{tabular}{ccccccccccc}
\hline Categorias & Evocações & A & B & C & D & E & F & G & H & I \\
$\%$ & $\%$ & $\%$ & $\%$ & $\%$ & $\%$ & $\%$ \\
\hline Transformação & Transformação dos materiais & 50 & 44 & 43 & 48 & 45 & 42 & 35 & 50 & 36 \\
Experimentação & Experimentos & 22 & 32 & 27 & 30 & 30 & 30 & 8 & 17 & 22 \\
Motivações & $\begin{array}{c}\text { Descoberta de substâncias e } \\
\text { desenvolvimento de técnicas } \\
\text { laboratoriais }\end{array}$ & 27 & 24 & 20 & 22 & 25 & 20 & 45 & 16 & 20 \\
\hline Conceitos & Coisas diferentes & - & -10 & - & - & 8 & 12 & 17 & 22
\end{tabular}

A análise da tabela mostra que apenas quatro das sete categorias iniciais estão representadas nas evocações de cinco turmas, enquanto aparecem apenas três das categorias nas demais turmas. As respostas dos alunos se enquadraram nas categorias Transformação, Experimentação, Motivações e Conceitualização. Essas quatro categorias aparecem nas turmas $\mathbf{C}, \mathbf{F}, \mathbf{G}, \mathbf{H}$ e I. Já nas turmas $\mathbf{A}, \mathbf{B}, \mathbf{D}$ e E, as respostas dos alunos não se enquadram na categoria Conceitualização, identificando-se apenas as outras três.

A categoria Transformação foi a mais citada de acordo com as respostas, em todas as turmas, representando pelo menos $35 \%$ das respostas, ou seja, ocorreu um aumento quando comparado aos resultados da Figura 7.4.

A segunda categoria mais significativa foi a Experimentação, cuja porcentagem se enquadra em um intervalo de 8 a $32 \%$. Os alunos simplesmente acham que um dos pontos em comum entre os dois objetos de estudo (Alquimia e Química) seria que em ambos existiam experimentos, esquecendo de citarem um fator relevante. $A$ diferença entre eles é a questão do objetivo ao realizar o experimento, porém algumas dessas explicações aparecem na segunda questão que será apresentada mais adiante.

Logo em seguida, a terceira categoria mais citada foi Motivações. As respostas que se enquadram nessa categoria referiam-se ao desenvolvimento $e$ aprimoramento de técnicas laboratoriais bem como à descoberta de muitas 
substâncias, na época em que prevalecia a Alquimia. As justificativas utilizadas pelos alunos, em sua grande parte, referem-se ao emprego, até hoje, dessas substâncias e técnicas em laboratórios químicos.

E, por último, a questão da Conceitualização que, nesse caso, se restringe apenas em explicar que a Alquimia e a Química são coisas diferentes, não aparecendo em todas as turmas, mas em apenas cinco delas.

Observa-se claramente, a partir dos gráficos apresentados na figura 7.5, que ocorreu sim uma ressignificação dos conceitos em relação à Alquimia e Química, pois, no pré-teste, a partir da tabulação das respostas foram evidenciadas visões equivocadas dos alunos. No pós-teste, observamos que ocorreu modificação dessas visões. O ponto em comum entre a Alquimia e a Química é que ambos trabalham com as transformações dos materiais.

Essa ressignificação pode ser explicada de acordo com as teorias de Vygotsky (1998), que enfatiza a importância da intervenção do professor e de outros colegas no desenvolvimento de cada indivíduo envolvido na discussão e no jogo, servindo de objeto de interação que pode ser considerado legítimo promotor de aprendizado escolar.

TRANSFORMAÇÃo

Agora eu entendi que o que tem em comum entre a Alquimia e a Química é que as duas traballham com as transformações das coisas.

Estudante 23-I

Sim, existe ponto em comum sim, os fenômenos e transformações.

Estudante 4-F

O ponto em comum é simplesmente a transformação dos materiais.

Estudante 30-A

Quadro 7.25: Pontos em comum entre Alquimia e Química- Transformação.

EXPERIMENTAÇÃO

O que tem em comum é que as duas trabalham com experiências.

Estudante 15-C

Os experimentos são o ponto em comum.

Estudante 1-A.

Quadro 7.26: Pontos em comum entre Alquimia e Química- Experimentação 


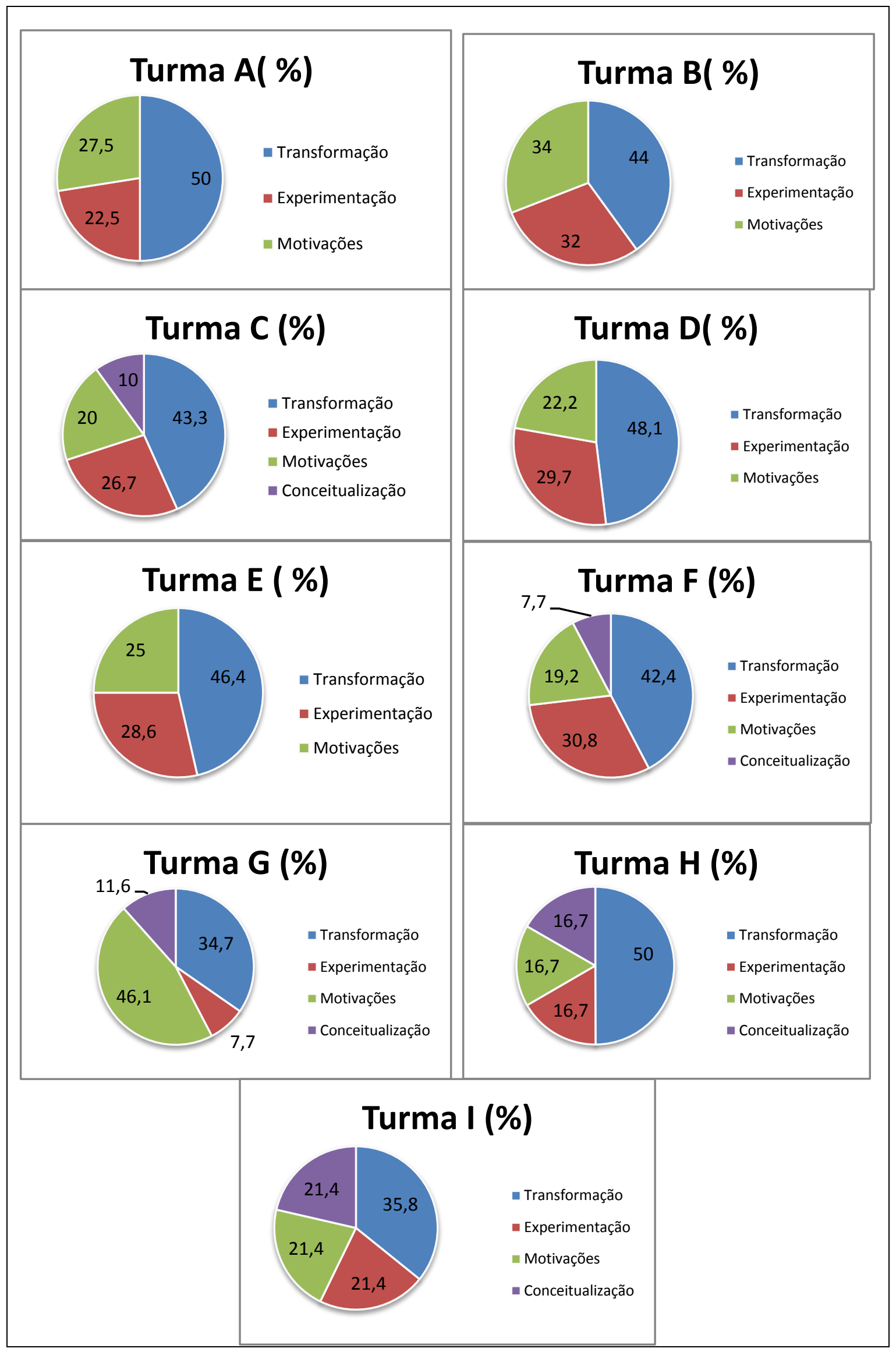

Figura: 7.5: Gráficos de 9 turmas com os resultados do ponto em comum entre Alquimia e Química 
MOTIVAÇõES

A Alquimia e a Química tem um ponto em comum, ambas em suas pesquisas descobriram novas substâncias.

Estudante 7-B

Desenvolveram técnicas usadas em laboratórios até hoje.

Estudante 1-G

Sei que o ponto em comum é o uso de substâncias descobertas e aprimoramento de técnicas

laboratoriais.

Estudante 5-H

Quadro 7.27: Pontos em comum entre Alquimia e Química- Motivações

CONCeitualização

São coisas diferentes, porém muito importantes para a Ciência.

Estudante 12-I

São coisas diferentes que trabalham com a transformação dos materiais.

Estudante 21-H

Quadro 7.28: Pontos em comum entre Alquimia e Química- Conceitos

A segunda questão apresentada no pós-teste foi: Existe alguma diferença entre a Alquimia e a Química?

Foi possível identificar apenas três categorias trabalhadas anteriormente que foram: Transformação, Experimentação e Conceitualização. A primeira não apresenta subcategorias, porém a segunda e a terceira se desdobram em duas subcategorias cada uma. Esses resultados são apresentados na Tabela 8.10, nos gráficos representados na Figura 7.6 e nos Quadros 7.29, 7.30 e 7.31, em que aparecem algumas das respostas dos estudantes.

As três categorias aparecem nas respostas das turmas A, B, C, D, H e I. Observamos que a categoria menos presente em todas as seis turmas foi Transformação, cuja porcentagem atingiu um intervalo médio de $10 \%$ a 20\%, como mostrado na Tabela 7.10 Nesse caso específico, a maioria das respostas se referiam à forma de pensamento. Muitos alunos descreveram suas idéias com base na questão da mudança de algo concreto para abstrato (Quadro 7.30). Já nas turmas $\mathbf{E}, \mathbf{F}$ e $\mathbf{G}$, as descrições das respostas dos educandos não se enquadram nessa categoria. 
As respostas dos educandos pertencentes a oito das nove turmas se são classificáveis na segunda categoria, Experimentação, que só não aparece na turma G. Observamos que essa categoria foi expressiva (14\% e 61\%), se comparada à Transformação (Tabela 7.10, Figura 7.6).

A categoria Experimentação, de acordo com as respostas dos alunos, pode ser subdividida em duas subcategorias. A primeira refere-se à diferença entre as funções estabelecidas pelos experimentos e, a segunda, à diferença dos métodos empregados na realização dos mesmos. Observamos, também, que a primeira subcategoria tem representação em oito turmas com exceção apenas da turma $\mathbf{G}$ e as respostas das demais turmas variam em um intervalo de 7\% a 61\% (exemplos, Quadro 7.30). Já a segunda subcategoria tem representatividade em apenas quatro das nove turmas (A, B, C e I), com respostas na faixa de $3 \%$ a $15 \%$, não sendo tão significativas como as demais citadas. Mas uma vez, comparando-se a análise diagnóstica inicial com a final, observa-se que ocorre ressignificação dos conceitos em relação à Alquimia e Química.

Tabela 7.10: Diferença entre Alquimia e Química

\begin{tabular}{|c|c|c|c|c|c|c|c|c|c|c|}
\hline Categorias & Evocações & $\bar{A}$ & B & C & $\bar{D}$ & $\bar{E}$ & $\bar{F}$ & $\overline{\mathbf{G}}$ & $\bar{H}$ & I \\
\hline Transformação & $\begin{array}{c}\text { Maneira de pensar } \\
\text { (Abstrato } \rightarrow \\
\text { concreto) }\end{array}$ & 10 & 20 & 10 & 14,8 & - & $\overline{-}$ & $\overline{-}$ & 10 & 14.3 \\
\hline \multirow[t]{2}{*}{ Experimentação } & $\begin{array}{l}\text { Diferença entre as } \\
\text { funções dos } \\
\text { experimentos }\end{array}$ & 27,5 & 28 & 30 & 14,8 & 21,4 & 61,5 & - & 10 & 7,1 \\
\hline & $\begin{array}{l}\text { Diferença nos } \\
\text { métodos que } \\
\text { realizavam os } \\
\text { experimentos }\end{array}$ & 15 & 12 & 3,3 & - & - & - & - & - & 7,1 \\
\hline \multirow[t]{2}{*}{ Conceitualização } & Teorias & 22,5 & 24 & 20 & 29,7 & 25 & - & 46.1 & 30 & 25 \\
\hline & Objetivos & 25 & 16 & 36,7 & 40,7 & 52,6 & 38,5 & 53,9 & 50 & 46,5 \\
\hline
\end{tabular}

A terceira e última categoria construída a partir da tabulação das respostas dos alunos foi Conceitualização. As descrições que se enquadram nessa categoria foram observadas nas nove turmas. A partir dos resultados, sumariados nos gráficos 
apresentados na Figura 7.6, constatamos que essa última categoria foi a mais citada nas respostas dos educandos, sendo a mais significativa e mostrando a ressignificação dos alunos quanto aos conceitos de Alquimia e Química. Podemos ver exemplos das citações dessa categoria no Quadro 7.31.

Observamos o desdobramento de Conceitualização em duas subcategorias: Teorias e Métodos. A subcategoria "Teorias" só não está representada na turma F, sendo significativa nas demais turmas, oscilando entre $20 \%$ e $46 \%$ das respostas. Já a segunda subcategoria, relacionada aos métodos, foi identificada em todas as turmas em porcentagens que oscilam em um intervalo de $16 \%$ a $54 \%$ das respostas.

\section{TRANSFORMAÇão}

A diferença principal entre Alquimia e Química era a forma como os praticantes pensavam.

Estudante 12-B

O fator que diferencia as duas é que uma as pessoas pensavam de forma abstrata e a outra era pensada de forma mais concreta, metódica.

Estudante 23-C

Simplesmente a diferença era na maneira em que os alquimistas e químicos pensavam.

Estudante 38-A

Uma é ciência e a outra é uma mistura de ciência, arte, religião, entre outros. Estudante 9-I

Quadro 7.29: Diferença entre Alquimia e Química- Transformação

\section{EXPERIMENTAÇÃ̃O}

FUNÇÃo

A diferença é em relação aos objetivos que envolvem os experimentos, na Química as experiências são feitas para comprovar algo, segue um método, já na Alquimia eles não sabiam muito bem o que estavam fazendo, pelo menos no início.

Estudante 23-H

Na Química segue um roteiro, um método, já na Alquimia isso não existia.

Estudante 39-A 
As funções das experiências são completamente diferentes, porque são épocas muito diferentes.

Estudante 22-F

MÉTODOS

Os métodos usados nos experimentos são diferentes.

Estudante 25-D

Os métodos usados na Alquimia são arcaicos na Química são mais atuais, mais modernos.

Estudante 30-A

Os métodos usados na época da alquimia foram aprimorados e hoje são usados na Química, um era mais simples e outro é mais técnico.

Estudante 20-B

Quadro 7.30: Diferença entre Alquimia e Química- Experimentação

\section{CONCEITUALIZAÇÃo}

\section{TEORIAS}

O que vai diferenciar a Alquimia e a Química são as teorias que envolvem cada uma delas. Estudante 10-I Estudam teorias diferentes, muita coisa diferente, épocas diferentes. Estudante 15-C

\section{OBJETIVOS}

Os objetivos da alquimia foram diferentes dos da Química, a alquimia buscava simbolicamente a pedra filosofal e a transmutação de metais e a química aprimora métodos e auxilia nas descobertas científicas para ajudar a humanidade.

Estudante 19-G

A Alquimia tinha como objetivo a transmutação, já a Química como um dos objetivos a descoberta de novas substâncias.

Estudante 17-A

Quadro 7.31: Diferença entre Alquimia e Química- Conceitualização. 


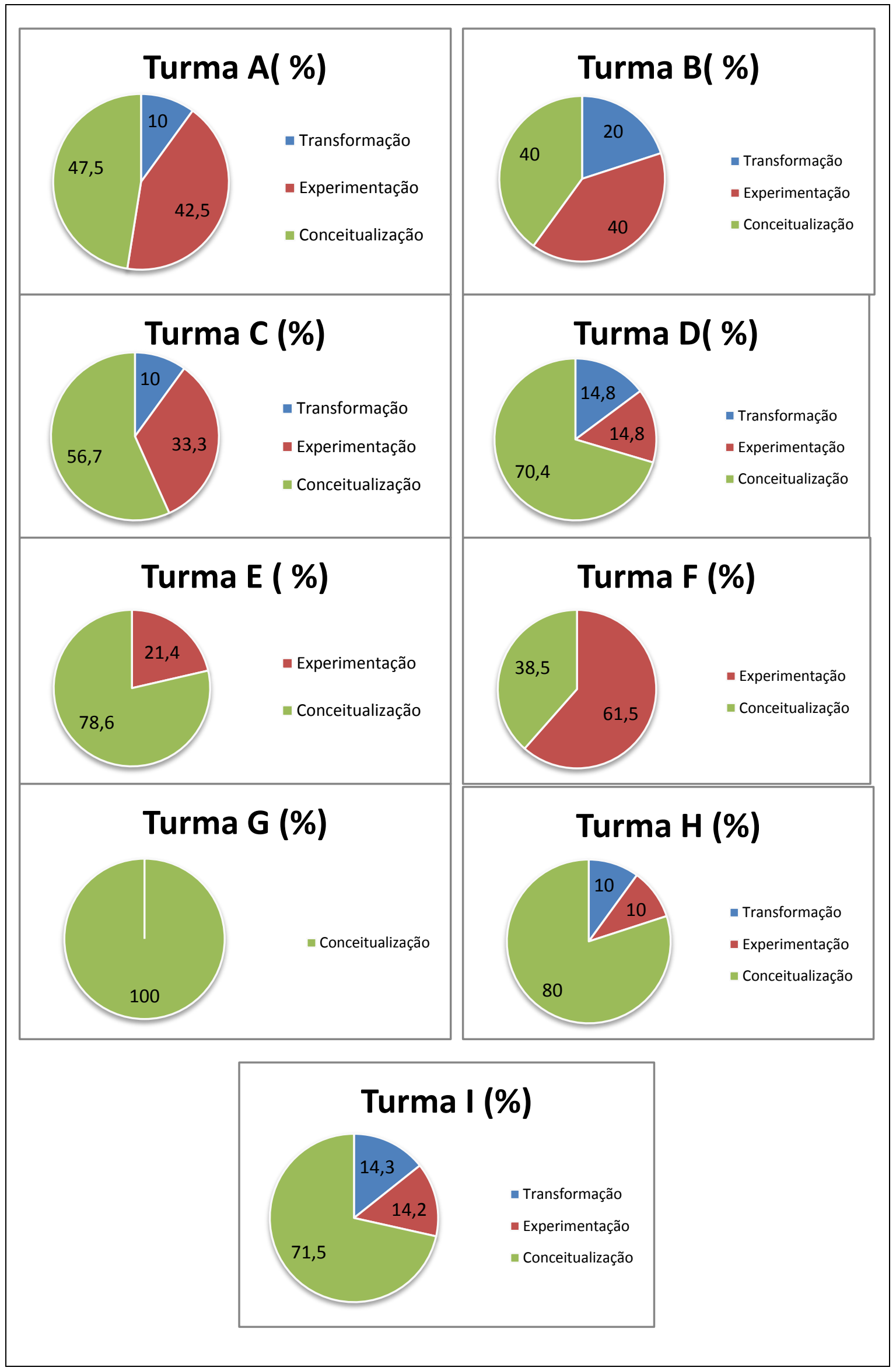

Figura: 7.6: Gráficos das 9 turmas com os resultados da diferença entre Alquimia e Química. 
Capítulo 8: CONSIDERAÇÕES FINAIS 
A pesquisa apresentada desenvolveu-se na perspectiva da análise qualitativa fundamentada na teoria histórico-cultural, sendo seu interesse principal estudar o emprego do Jogo Autódromo Alquímico como mediador da aprendizagem no ensino de Química. A aplicação do jogo foi realizada pela pesquisadora, professora regente de algumas das turmas, e por outro professor de Química, em nove turmas de nono ano do Ensino Fundamental de uma escola da rede privada na cidade de Itabuna, no estado da Bahia.

A atividade lúdica elaborada para a realização desta pesquisa foi denominada de "Autódromo Alquímico" e buscou a ressignificação dos conceitos abordados, pela distinção entre duas formas de pensar sobre as transformações dos materiais, a da Alquimia e a da Química. Essa atividade foi desenvolvida em sete etapas distintas que abrangeram 10 horas-aula, consistindo da aplicação do teste diagnóstico, do uso de um filme, do estudo dirigido, discussões, pesquisas e do próprio autódromo, em que os alunos são os sujeitos ativos da ação. O estudo abrangeu 263 alunos de idade regular em um intervalo de tempo de cinco anos, entre os anos de 2006 e 2010.

Considerando as atividades lúdicas como favorecedoras dos processos de ensino e aprendizagem e consoantes com as diretivas oficiais para a educação no Brasil, a hipótese de pesquisa da presente Dissertação é a de que o jogo didático, Autódromo Alquímico propicie um ambiente de aprendizagem colaborativa entre os estudantes, favorecendo aos alunos serem sujeitos do processo, com mediação do professor.

Assim sendo, o objetivo geral desta Dissertação foi o de criar, desenvolver, aplicar e avaliar uma atividade lúdica, planejada e elaborada na forma de um jogo didático, mas especificamente criar, desenvolver e aplicar o Autódromo Alquímico, um jogo didático concebido para mediar o conhecimento das transformações dos materiais, considerando aspectos do universo cultural de alunos do último ano do Ensino Fundamental.

Os dados foram obtidos por meio de três análises diagnósticas, questionários, filmagens e entrevista semi-estruturada com o professor e com 
os próprios alunos, sendo tratados com ferramentas da análise de conteúdo (Bardin, 2000).

A categorização das respostas foi realizada a partir das evocações registradas pelos alunos nos instrumentos diagnósticos, para cada uma das palavras empregadas (Bardin, 2000; Tabela 6.3), levando à construção de sete categorias. Essas categorias espelham as convergências e divergências entre alquimia e química durante o desenvolvimento das etapas do jogo, permitindo que se percebam a ampliação e evolução dos conceitos desenvolvidos durante sua aplicação. Mais especificamente, na análise diagnóstica inicial as respostas dos alunos se enquadram nas sete categorias e, à medida que vão sendo aplicadas as etapas do jogo, essas categorias vão desaparecendo, como apresentado na transcriação das filmagens apresentadas nos Quadros 7.18 a 7.24. A culminância é na análise diagnóstica final, onde aparecem apenas três categorias.

Nas transcriações das filmagens referentes à etapa de análise diagnóstica continuada, observa-se que um conjunto de funções psicológicas superiores é mobilizado em vários momentos dos episódios mostrados (Quadros 7.18 a 7.24). A FPS que mais se destacou foi Atenção, pois, em todos os episódios os alunos mostram preocupação na manutenção do foco, indicando que os alunos já haviam desenvolvido essa FPS, o que contribuiu para o sucesso da estratégia didática adotada em sala de aula.

A partir da análise dos resultados, percebeu-se que o Autódromo Alquímico conduziu os estudantes a uma abordagem sócio-cultural do processo, culminando em diversas discussões referentes às relações entre Alquimia e Química. As etapas de aplicação do Autódromo Alquímico estimularam distintas habilidades nos alunos tais como: facilidade em dialogar, tomar decisões, criticar, argumentar, liderar o grupo, coleta de informações, estratégias de ação, o aprendizado com os outros, a participação conjunta, a responsabilidade, 0 respeito pelos demais e, ainda, a estimulação do crescimento e da autonomia.

Os resultados encontrados corroboraram com a hipótese de que o jogo didático, Autódromo Alquímico propicia um ambiente de aprendizagem colaborativa entre os estudantes, favorecendo aos alunos serem sujeitos do 
processo. Demonstraram, também, a existência de uma relação direta entre a aplicação da atividade lúdica e a ressignificação e aprofundamento do conhecimento em Química, em consonância com os objetivos da aplicação do jogo.

Conclui-se que o Jogo foi benéfico para 0 processo de ensino e aprendizagem em Ciências, pois houve aprendizagem e ressignificação dos conceitos Alquimia e Química. Também foi perceptível o desenvolvimento de várias habilidades apontadas como importantes para a formação de um cidadão crítico e reflexivo.

Essas características do Autódromo Alquímico são importantes, pois grande parte, cerca de $80 \%$ vide tabela 7.4 , dos jogos relatados na literatura enfatiza fortemente a memorização, contribuindo pouco para que o aluno desenvolva outros aspectos cognitivos relacionados às FPS, embora a atividade lúdica, por suas características inerentes, possa, ainda assim, trazer contribuições para os alunos no que se refere às competências necessárias para a execução de trabalhos em equipe, por exemplo.

Assim, para que o jogo atinja seus objetivos pedagógicos, é fundamental que o professor estabeleça claramente os objetivos e pressupostos teóricos de sua prática educativa, para que a seleção dos instrumentos que pretende empregar seja objetiva.

O professor pode valer-se das atividades lúdicas como um instrumento para verificar dificuldades na aprendizagem de seus alunos, de forma a atuar diante das limitações e dificuldades deles. Ao escolher as atividades lúdicas, o professor deve ter bem claro que esse instrumento deve ser mais um recurso de trabalho em prol da aprendizagem de seus alunos.

É importante ressaltar que o emprego de atividades lúdicas (jogos) não substitui os instrumentos formais de ensino-aprendizagem, mas funciona como um recurso complementar inovador e eficiente para auxiliar nesse processo. 


\section{Capítulo 9: REFERÊNCIAS BIBLIOGRÁFICAS}


ANDRÉ, M. E. D. A. Pesquisa em Educação: Abordagens Qualitativas. São Paulo: EPU, 1986, p. 112.

ANTUNES,C. Manual de Técnicas: de dinâmicas de grupos: sensibilização e ludopedagogia. Vozes. São paulo, 1987.

ANTUNES,C. Jogos para estimulação das múltiplas inteligências. Vozes. São Paulo 2003.

ARAÚJO, S. A. Possibilidades Pedagógicas do Cinema em sala de aula. Revista Espaço Acadêmico. n.79, 2007.

ARROIO, A. GIORDAN, M. O vídeo educativo: Aspectos da Organização do Ensino. Química Nova na Escola. n..24, 2006.

BARDIN, L. Análise de conteúdo. Lisboa: Edições 70, 2000, p. 225.

BANKS, R.C. The tile game. The Chemical Educator, v.1, n.2, s00897960021a, 1996.

BAZÍLIO, H.O; SOARES, M.H.F.B. Elaboração de jogos e atividades lúdicas para ensinar o conceito de lei de Lavoisier. In : CONGRESSO DE PESQUISA, ENSINO E EXTENSÃO DA UFG- CONPEEX, 2, Anais [CD-ROM], Goiânia: UFG, 2005.

BENJAMIN, W. Reflexões: a criança, o brinquedo, a educação. Summus, São Paulo, 1984.

BOGDAN, R. C. \& BIKLEN, S. K. Investigação qualitativa em educação : uma introdução a teoria e aos métodos. Porto : Porto Editora, 1994, p. 335.

BORGES, R.M.R.; SCHWARZ, V.O. O Papel dos jogos educativos no processo de qualificação de professores de ciências. In: Encontro Ibero-Americano de Coletivos escolares e redes de professores que fazem investigação na escola, 4. Lajeado, RS, 2005.

BOMTEMPO, E. Brinquedos: Critérios de Classificação e Análise. Cadernos de EDM. São Paulo, v.2, n. 2., 1990, p.36-44.

BOMTEMPO, E. Brinquedo e Educação: na escola e no lar. Psicologia Escolar e Educacional, v. 111, n. 1, 1999, p. 61-69.

BRASIL, Ministério da Educação. Secretaria de Educação Média e Tecnológica. Parâmetros Curriculares Nacionais: Ensino Médio: Ciências da Natureza, Matemática e suas Tecnologias. Brasília: Ministério da Educação/ Secretaria de Educação Média eTecnológica, 1999, p. 364.

BRASIL, Ministério da Educação. Secretaria de Educação Média e Tecnológica. Ciências da Natureza, Matemática e suas Tecnologias. Brasília: Ministério da Educação, SEMTEC, 2002, p. 144. 
BRASIL, Ministério da Educação. Secretaria de Educação Média e Tecnológica. Orientações curriculares do Ensino Médio. Brasília: Ministério da Educação, 2004, p. 140.

BROUGÈRE, G. Brinquedo e Companhia. São Paulo: Cortez, 2004.

BRUCE, T. Time to Play in Early Childhood Education. London: Hodder \& Stoughton, 1991.

CABRERA, W.B.; SALVI, R. A ludicidade no Ensino Médio: Aspirações de Pesquisa numa perspectiva construtivista. In: ENCONTRO NACIONAL DE PESQUISA EM EDUCAÇÃO EM CIÊNCIAS, 5. Atas, 2005.

CALDEIRA, C. G. Dos professores de química ao professores alquímicos :uma transmutação no profissional docente. . Minas Gerais, 2007. 107p. Dissertação de Mestrado em educação- Universidade de Uberaba.

CAMARGO, M. M. JUNIOR, C. R. O; MEDEIROS, O. A. A Importância dos jogos no processo educacional. Revista Virtual EFArtigos, 1 (16), 2004,

CARVALHO, A.M.A et al.; MAGALHÃES, C.M.C.; PONTES, A.R.; BICHARA, D.I. (orgs.). Brincadeira e cultura: viajando pelo Brasil que brinca, o Brasil que brinca. São Paulo: Casa do Psicólogo, v. 1, 2003, p. 206.

CASBY, M. W. Developmental Assessment of Play: a Model for early intervemtion. Communication Disorders Quarterly . v.24, n.4, 2003.

CAVALCANTI, E.L.D.; SOARES, M.H.F.B. O uso do jogo de roles (roleplaying game) como estratégia de discussão e avaliação do conhecimento químico.

Revista Electrónica de Enseñanza de las Ciencias, v.8, n.1, p.255-282, 2009.

CHASSOT, Attico. Alfabetização científica: questões e desafios para a educação. 2. ed. ljuí: Unijuí, 2001a.

CHASSOT, Attico. A ciência através dos tempos. 12. ed. São Paulo: Moderna, 2001b.

CHASSOT, Attico. Pra que $(m)$ é útil o ensino? Alternativas para um estudo (de química) mais crítico. Canoas: ULBRA, 1995.

CHERIF, A. H.; SOMERVILL, C. H. Maximizing learning: using role playng in the classroom. The American Teacher, vol. 57, $n^{\circ}$ 1, p.28-33, jan, 1995.

CHERIF, A. H.; VERNA, S.; SOMERVILL, C. H. From the Los Angeles Zoo to the Classroom - Transforming Real Cases in Role-Play into Productive Learning Activities. The American Biology Teacher, vol. 60, nº 8, p.613-616, oct, 1998.

CHINNICI, J. P.; YUE, J. W.; TOREES, K. M. "Human Chromosomes" in RolePlaying Mitosis \& Meiosis. The American Biology Teacher, vol. 66, $\mathrm{n}^{\circ} 1$, jan, p35-39. 2004. 
COHEN, D.; BEN-Zvi, R.; HOFSTEIN, A.; RAHAMIMOFF, R. On brain, medicines \& drugs: A module for the "science for all" Program. The American Biology Teacher, vol 66, $n^{0} 1$, p. 9-19, jan, 2004

COLL, César (org.).Desenvolvimento psicológico e educação. Vol III. P.Alegre: Artmed, 1996.

CRUTE, T. D. Classroom nomeclature Games- BINGO. Journal of Chemical Education, v.77, n.4, p.481, 2000.

CUNHA, H.S. Brinquedo, desafio e descoberta. 1ª edição. FAE/MEC/RJ. 1998.

CUNHA, M. B. Jogos de Química: Desenvolvendo habilidades e socializando o grupo. In: ENCONTRO NACIONAL DE ENSINO DE QUÍMICA, 12, Goiânia (Universidade Federal de Goiás; Goiás), 2004. Anais, 028, 2004.

CUNHA, E. Afeto e Aprendizagem: Relação de Amorosidade e saber na prática pedagógica.Rio de Janeiro:Wak Ed. , 2008.

DAVIDOV, V. La enseñanza escolar y el desarrolo psíquico. Moscou: Progresso, 1988.

DEAVOR, J.P. Who wants to be a (chemical) millionaire? Journal of Chemical Education, v.78, n.4, p.467, 2001.

DKEIDER, I.M. The elements drawing. Journal of Chemical Education, v.80, n.5, p.501, 2003.

DRIVER, R. et al. Construindo conhecimento científico na sala de aula.

Química Nova na Escola, 1999, p. 31- 40.

DUARTE, M. C. Analogias na educação em ciências: contributos e desafios. Investigações em Ensino de Ciências. V. 10, n. 1, mar, 2005.

DUVEEN, J. \& SOLOMON, J. The great evolution trial: use of role-play in the classroom. Journal of College Science Teaching. V. 31, n. 5, 1994, p. 575586.

EICHLER, M.; DELPINO, J.C. Carbópolis, um software para Educação Química. Química Nova na Escola. n.11, xxp., 2000.

EICHLER, M.; JUNGES, F.; DELPINO, J.C. O papel do jogo no ensino de radioatividade: os softwares Urânio-235 e a Cidade do átomo. Novas Tecnologias na Educação. v.3, n.1, 2005.

ELIOMAR, I.B.; FADINI, L. F. C. G. O brincar e o pensar. Revista do professor. Porto Alegre, v.21, n.81, p.11-15, jan./mar. 2005.

ELKONIN, D.B. Psicologia do jogo. São Paulo: Martins Fontes, 1998. 
FACCI, M. G. D. A periodização do desenvolvimento psicológico individual na perspectiva de Leontiev, Elkonin e Vigotski. In: Cadernos do Cedes. Centro de Estudos Educação e Sociedade - Vol. 1 - São Paulo: Cortez, Campinas, Cedes, 1980.

FREIRE, P. Pedagogia da autonomia: saberes necessários à prática educativa. São Paulo: Paz e Terra, 1996, p. 165.

FREITAS, M. T. A. Vygotsky e Bakhtin. Psicologia e Educação: Um intertexto. São Paulo: Ática, 2006.

FREITAS, H.; JANISSEK, R. Análise léxica e análise de conteúdo: técnicas complementares, seqüenciais e recorrentes para análise de dados qualitativos. Porto Alegre: Sphinx, 2000.176p.

FRIEDMANN, A. O direito de brincar: A brinquedoteca. Scritta editorial, São Paulo, 2000.

GALLAHUE, D. L. Development Movement Experiences for Childrens. New York: John Wiley \& Sons, 1982.

GARÓFANO, V. V.; CAVEDA, J. L. C. O jogo no currículo da educação infantil. In: MURCIA, J. A. M. Aprendizagem através do jogo. Porto Alegre: Artmed, 2005.

GEERTZ, C. A Interpretação das Culturas. Rio de Janeiro: Guanabara Koogan, 1989.

GRANATH, P.L; RUSSELL, J.V. Using games to teach chemistry. 1. The old prof card game. Journal of Chemical Education, v.77, n.4, p.485, 2000.

GÓES, M.C.R. As relações intersubjetivas na construção de conhecimentos. In: GỎES, M.C.R. \& SMOLKA, A. L. B. (Orgs.) A significação nos espaços educacionais: Interação social e subjetivação. Campinas, SP: Papirus, 1997.

GOLDFARB, Ana Maria Alfonso. A complexa abordagem dos cenários de laboratório na literatura alquímica. In: GOLDFARB, Ana Maria Alfonso. 0 laboratório, a oficina e o ateliê: a arte de fazer o artificial. São Paulo: EDUC, 2002, cap. 1, p. 11-38.

GOLDFARB, A.M. A. Da Alquimia a Química. São Paulo: Landy , 2001.

GÓMES, A. I. P. As funções Sociais da Escola. In SACRISTÁN, J. G.; GÓMES.Compreender e Transformar a Escola. Porto Alegre: Artmed, 1998.

HELSER, T.L. Safety wordsearch" Journal of Chemical Education, v.76, n.4, p495, 1999.

HUDSON, M. Acting out muscle contraction. The American Biology Teacher, vol. 65, $n^{0} .2$, p.128-132, February, 2003. 
HUIZINGA, J. Homo Ludens - O jogo como elemento da cultura. São Paulo, SP: Perspectiva S.A. 1996, p. 243.

KISHIMOTO, T.M. Jogo, Brinquedo, Brincadeira e a Educação. São Paulo: Cortez, 1996, p.183.

KISHIMOTO, T.M.. O Jogo e a Educação Infantil. São Paulo: Pioneira, 1998.

KISHIMOTO, T.M. O Brincar e suas teorias. São Paulo: Pioneira Thomson Learning, 2002.

KRASILCHIK, M. Caminhos do ensino de ciências no Brasil. Em Aberto. Brasília, n. 55, 1992, p. 4-8.

LA TAILLE, Y.; OLIVEIRA, M. K.; DANTAS, H. Piaget, Vygotsky e Wallon: teorias psicogenéticas em discussão. São Paulo: Summus, 1999.

LEAL, M. C. Didática da Química: Fundamentos e Práticas para o Ensino Médio. Belo Horizonte: Dimensão, 2009, 120 p.

LEMOS, M. M.;SANTANA, E.M. PASSOS,C. R. S. Estequiometria na cozinha. In: 32 ${ }^{\mathrm{a}}$ RASBQ (32 ${ }^{\mathrm{a}}$ Reunião Anual da Sociedade Brasileira de Química). Anais, Fortaleza- Ceará, 2009.

LEMOS, M.M.; SANTANA, E.M. Ecocaneca .In: 32ª RASBQ (32ª Reunião Anual da Sociedade Brasileira de Química). Anais, Fortaleza- Ceará, 2009.

LEONTIEV, A. N. O desenvolvimento do psiquismo. Lisboa: Livros Horizonte, 1978.

LEONTIEV, A. N.. Os Princípios Psicológicos da Brincadeira Pré-escolar. In: VIGOTSKII, Lev. S.; LURIA, Alexander R.; LEONTIEV, Alexis N. Linguagem, desenvolvimento e aprendizagem. São Paulo: Ícone: Editora da Universidade de São Paulo, 1988.

LIMA, J. M. 0 jogar e o aprender no contexto educacional: uma falsa dicotomia. 2003. 246f. Tese (Doutorado em Educação) - Faculdade de Filosofia e Ciências - UNESP - Campus de Marília.

LIMA, J. M. A brincadeira na teoria histórico-cultural: de prescindível a exigência na Educação Infantil. In: GUIMARÃES, M. C. Perspectivas para Educação Infantil. Araraquara: Junqueira \& Marin, 2005.

LOWENFELD, V. \& BRITAIN, W.L Desenvolvimento da capacidade criadora. São Paulo: Mestre Jou,1977.

LURIA, A. Curso de Psicologia Geral. Vol. II, R.Janeiro: Ed. Civilização Brasileira, 1991.

LURIA, R. Memória e Pensamento. São Paulo: Martins Fontes, 1992. 
MARCELLINO, N. C. Pedagogia da Animação. Papirus editora, São Paulo, 1990

MÁRKOVA, D. V. A influencia de la literatura soviética para niños en el juego creativo. No compêndio: Los juegos creativos en el jardin de la infancia. Moscou, 1951.

MARTINS, L. M. A natureza histórica-social da personalidade. In: Cadernos do Cedes. Centro de Estudos Educação e Sociedade - Vol. 1, (1980) - São Paulo: Cortez, Campinas, Cedes, 1980.

MARX, J. G.; Honeycutt K. A.; Clayton, S. R.; Moreno, N. P. The Elizabeth Towns incident: An inquiry-based approach to learning anatomy developed through high school-university collaboration. The American Biology Teacher, vol. 68, n. 3, p. 140-147, march 2006.

MELO,C. M.R. As atividades lúdicas são fundamentais para subsidiar ao processo de construção do conhecimento (continuação). Información Filosófica. V.2 ำ1 2005 p.128-137.

MELLOU, E. A Theoretical Perspective on the Relationship between Dramatic Play and Creativity. Early Child Development and Care. V. 100, 1994, p. 7792.

MELLOU, E. A. Review of the relationship between dramatic play and creativity in Young children. Early Child Development and Care. V. 112, 1995, p. 85 107.

MENDONÇA, D. F.; SOARES, M. H. F. B.; Jornal Científico: Construção E Aprendizagem De Conceitos Químicos Utilizando-Se Uma Atividade Lúdica. In: CONGRESSO DE PESQUISA, ENSINO E EXTENSÃO DA UFG - CONPEEX, 2., 2005, Goiânia. Anais eletrônicos do II Seminário de Pesquisa e Pós Graduação [CD-ROM], Goiânia: UFG, 2005.

MENEZES, E. T. e SANTOS, T. H. "Lúdici” (verbete). Dicionário interativo da Educação Brasileira - EducaBrasil. São Paulo: Midiamix Editora, http://www.educabrasil.com.br/eb/dic/dicionari.asp?id=59, visitado em 21 de out de 2008

METTRAU, M. Lúdico: o diálogo com a informática. In: Publicação quadrimestral do Centro de Informática na Educação - CIE/IBM Brasil ano $1, \mathrm{n}^{\circ} 1$ - julho/outubro de 1994.

MIRCEA, E. Forgerons et Alchimisteses, Paris: Flamarion, 1977.

MORAES, E. y REZENDE, D. (2009). Atividades lúdicas como elementos mediadores da aprendizagem no ensino de ciências da natureza. Enseñanza de las Ciencias, Número Extra VIII Congreso Internacional sobre Investigación em Didáctica de las Ciencias, Barcelona, pp. 1008-1012. http://ensciencias.uab.es/congreso09/numeroextra/art-1008-1012.pdf 
MOREIRA, L.M. O Jogo teatral no ensino de Química; contribuições para a construção da cidadania. São Paulo, 2008. 154p. Dissertação de Mestrado em ensino de ciências- Programa de Pós- Graduação Interunidades em Ensino de Ciências- Universidade de São Paulo.

MOREIRA, L. M.; VOGEL, M.; REZENDE, D.B. Prática de Ensino em Química: o olhar de quem aprende! XIII Encontro Nacional de Didática e Prática de Ensino, 13, Recife, 2006. Anais. Recife: ENDIPE, 2006. 1 CD-ROM. ISBN: 853730068-3.

MORTMER, E. F. Construtivismo, mudança conceitual e ensino de ciências: para onde vamos? Investigações em Ensino de Ciências. 1996.

MORIN, E. Os sete saberes necessários à educação do futuro. São Paulo: Cortez, 2000.

MOLL, L. C. Vygotsky e a educação - implicações pedagógicas da psicologia sóciohistórica. P. Alegre, Artes Médicas, 1996

MOYLES, J. R. Só Brincar ? O papel do brincar na educação Infantil. Artmed Editora, Porto Alegre, 2002.

MUELLER, S. P. M. (Org.). Métodos para a pesquisa em Ciência da Informação. Brasília, Thesaurus, 2007. 190p. (Série Ciência da Informação e da Comunicação)

MURCIA, J.A.M. Aprendizagem através dos jogos. Porto Alegre: Artmed, 2005.

Nardi, R.; Borges, O. (orgs.). Atas do V ENPEC - Encontro Nacional de Pesquisa em Educação em Ciências, n 5, ISSN: 1809-5100, 2005.

NEGRINE, A. Terapias corporais: a formação pessoal do adulto. Porto Alegre: Edita, 1998.

OLIVEIRA; I. T.; SANTANA, E.M.; MAIER, S. F. Análise de livros didáticos: Os conceitos de transformações químicas. In: XIV Encontro Nacional de Ensino de Química. Anais. Curitiba-PR, 2008.

OLIVEIRA, A.S.; SOARES, M.H.F.B. Júri químico: uma atividade lúdica para discutir conceitos Químicos. Química Nova na Escola. n.21, 2005.

OLIVEIRA, V. B. Jogos de regras e resolução de problemas. Petrópolis: Cortez, 2004.

OLIVEIRA, M. K. Vygotsky: aprendizado e desenvolvimento, um processo sócio-histórico. 4.ed. São Paulo: Scipione, 1999.

OLIVEIRA, M. K. O problema a afetividade em Vigotsky. In: De la Taille, Piaget, Vigotsky e Wallon: Teorias psicogenéticas em discussão. São Paulo: Summus, 1992. 
OLIVEIRA, P. Brinquedo e Indústria Cultural. Petrópolis, RJ: Vozes, 1986.

PASSOS, C. R. S.; SANTANA, E. M. Dominó Periódico. In: ENCONTRO NACIONAL DE ENSINO DE QUÍMICA, 12, Goiânia (Universidade Federal de Goiás; Goiás), 2004. Anais, 025, 2004.

PENONI, N.; SILVA, D.M.; CANTÃO, F.O; BARREIRA, M.E.S. Corrida Química: Jogo educativo que visa aquisição de conhecimentos químicos. In: REUNIÃO ANUAL DA SBQ, 26, Poços de Caldas, 2003. Anais, São Paulo: $S B Q$.

PERUZZO, F.M.; CANTO, E. L. Química na abordagem do cotidiano. 4 ed. São Paulo: Moderna, 2006.

PIAGET, J. A formação do símbolo na criança - imitação, jogo e sonho, imagem e representação. 3a ed. Rio de Janeiro: LTC, 1990, p. 370.

POSNER, $\mathrm{H}$. et al. Accomodation of a scientific conception toward a theory of conceptual change. Science\&Education. v.66, n.2, 1982, p.221-227.

PUGLISI, M.L.; FRANCO, B. Análise de conteúdo. 2. ed. Brasília: Líber Livro, 2005.

RATNER, Carl. A Psicologia sócio-histórica de Vygotsky: aplicações contemporâneas. P.Alegre: Artes Médicas, 1995.

REGO, T. C. Vygotsky: uma perspectiva histórico-cultural da educação. 12.ed. Petrópolis: Vozes, 2000.

RIBEIRO, A.; SANTANA, E.M. et. al. Oficinas Experimentais como apoio a professores de Química da 8 ${ }^{a}$ Série. in: VII Encontro de Educação em Química da Bahia. 2005. Jequié- Bahia. Anais do VII Encontro de Educação em Química da Bahia, UESB, Jequié- Bahia- 2005.

ROCHA, M.S.PM.L. Não brinco mais: a (des) construção do brincar no cotidiano educacional. ljuí, UNIJUÍ, 2000.

RODRÍGUEZ, F.P. (2007). Competencias comunicativas, aprendizaje y enseñanza de las Ciencias Naturales: un enfoque lúdico. Revista Electrónica de Enseñanza de las Ciências, 6, 2, 275-298.

ROWLING, J. K. Os contos de Beedle, O Bardo. Tradução de Lia Wyler. Rio de Janeiro : Rocco, 2007 a.

ROWLING, J. K. Harry Potter e as Relíquias da Morte. Tradução de Lia Wyler. Rio de Janeiro : Rocco, 2007 b.

ROWLING, J. K. Harry Potter e o Enigma do Príncipe. Tradução de Lia Wyler. Rio de Janeiro : Rocco, 2005.

ROWLING, J. K. Harry Potter e a Ordem da Fênix. Tradução de Lia Wyler. Rio de Janeiro : Rocco, 2003. 
ROWLING, J. K. Harry Potter e o Cálice de Fogo. Tradução de Lia Wyler. Rio de Janeiro : Rocco, 2001.

ROWLING, J. K. Harry Potter e o prisioneiro de Azkaban. Tradução de Lia Wyler. Rio de Janeiro : Rocco, 2000a.

ROWLING, J. K. Harry Potter e a Câmera Secreta. Tradução de Lia Wyler. Rio de Janeiro : Rocco, 2000b.

ROWLING, J. K. Harry Potter e a Pedra Filosofal . Tradução de Lia Wyler. Rio de Janeiro : Rocco, 2000c.

RUSSELL. J. V. Using games to teach chemistry- an annotated bibliography. Journal of Chemical Education, v.76, n.4, p.481, 1999.

SANMARTÍN, M. G. Aprendizagem de valores sociais através do jogo. In: MURCIA, Juan A. M. Aprendizagem através do jogo. Porto Alegre: Artmed, 2005.

SANTANA, E.M. e REZENDE, D.B. Perspectiva histórica do uso de jogos no ensino de ciências da natureza. In: XV Encontro Nacional de Ensino de Química. Universidade de Brasília. Anais. Brasília- Distrito Federal, 2010a.

SANTANA, E.M. e REZENDE, D.B. Desenvolvendo as Funções Psicológicas Superiores através de jogos e atividades lúdicas no ensino de Química. In: XV Encontro Nacional de Ensino de Química. Universidade de Brasília. Anais. Brasília- Distrito Federal, 2010b.

SANTANA, E.M. e REZENDE, D.B. Um estudo bibliográfico sobre o uso de

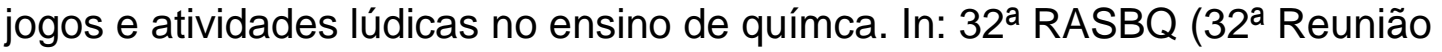
Anual da Sociedade Brasileira de Química). Anais, Fortaleza- Ceará, 2009a.

SANTANA, E.M. e REZENDE, D.B. O Uso de Jogos e atividades lúdicas na aprendizagem de química. In: 32ª RASBQ (32ª Reunião Anual da Sociedade Brasileira de Química). Anais, Fortaleza- Ceará, 2009b.

SANTANA, E. M. Autódromo Alquímico: Uma atividade lúdica para ensinar história da Alquimia e da Química. In: III Encontro de Química da Bahia. 2008. Universidade do Sudoeste da Bahia (UESB). Anais, Jequié- Bahia, 2008.

SANTANA, E. M. Bingo Químico: Uma atividade lúdica envolvendo símbolos e nomes dos elementos. In: SENEPT, 2008, Belo Horizonte. Anais. São Paulo: Universidade de São Paulo, Instituto de Física - Programa de Pós-Graduação, 2008a.

SANTANA, E. M. A Influência de atividades lúdicas na aprendizagem de conceitos químicos. In: SENEPT, 2008, Belo Horizonte. Anais. São Paulo: Universidade de São Paulo, Instituto de Física - Programa de Pós-Graduação, 2008b. 
SANTANA, E. M. e REZENDE, D. B.; ARROIO, A. O Uso do Filme Harry Potter como instrumento sensibilizador para aulas introdutórias de Química. In: XIV Encontro Nacional de Ensino de Química. Anais, Curitiba-PR, 2008.

SANTANA, E. M. e REZENDE, D. B. O Uso de Jogos no ensino de química: Uma oficina de aplicação para professores e alunos do curso de licenciatura em Química da Uesc. In: 31 ${ }^{\text {a }}$ RASBQ (31aㅡ Reunião Anual da Sociedade Brasileira de Química). Anais, Águas de Lindóia- São Paulo, 2008a.

SANTANA, E. M. e REZENDE, D. B. O Uso de Jogos no ensino e aprendizagem de Química: Uma visão dos alunos do 9a ano do ensino fundamental. In: XIV Encontro Nacional de Ensino de Química. Anais. CuritibaPR, 2008b.

SANTANA, E. M.; REZENDE, D. B. A influência de Jogos e atividades lúdicas no Ensino e Aprendizagem de Química. In: Encontro de Pesquisa em ensino de Ciências, 6, Florianópolis, 2007. Anais, Florianópolis- Santa Catarina, 2007a.

SANTANA, E. M.; REZENDE, D. B. Autódromo Alquímico: Uma atividade lúdica que envolve o tema História da Química. In: Encontro de Pesquisa em Ensino de Química, 4, São Paulo (USP), 2007, Anais, São Paulo- São Paulo- 2007b.

SANTANA, E. M.; WARTHA, E. J. O Ensino de Química através de jogos e atividades lúdicas baseados na teoria motivacional de Maslow. In: ENCONTRO NACIONAL DE ENSINO DE QUÍMICA, 13, Campinas (Unicamp), 2006. Anais, Campinas:São Paulo, 2006.

SANTANA, E.M. O Ensino de Química através de Jogos e atividades lúdicas baseados na teoria motivacional de Maslow. Ilhéus (Bahia), 2006, 62p. Monografia de Conclusão de Curso (Graduação) -Área de concentração: Ensino de Química, Colegiado do Curso de Licenciatura em Química, Departamento de Ciências Exatas e Tecnológicas- Universidade Estadual de Santa Cruz. Orientador: Edson José Wartha.

SANTANA, E. M. Jogo da Memória Químico. In: ENCONTRO DE QUÍMICA DA BAHIA, 1, Salvador (Bahia), 2005a. Anais, Universidade Estadual da Bahia (UNEB).

SANTANA, E. M. Tapete Periódico : Uma atividade lúdica para o ensino de química. In: ENCONTRO DE QUÍMICA DA BAHIA, 1, Salvador (Bahia), 2005b. Anais, Universidade Estadual da Bahia (UNEB).

SANTANA, E. M. Tapete Periódico. VII Encontro de Educação em Química da Bahia. Universidade do Sudoeste da Bahia (UESB). Anais, Jequié- Bahia, 2005c.

SANTOS, F. M. T. dos \& MORTIMER, E. F. Estratégias e táticas de resistência nos primeiros dias de aula de Química. Química Nova Na Escola. N.10, nov, 1999, p. 3842

SANTOS, S. M.P. A ludicidade como ciência. Rio de Janeiro: Vozes, 2001 
SANTOS, W. P. dos \& SCHNETZLER, R. P. Educação em química: compromisso com a cidadania. 3a ed. ljuí: Ed. Unijuí, 2003, p. 144.

SCHNETZLER, R. P. A pesquisa em ensino de química no Brasil: conquistas e perspectivas. Quim. Nova. V. 25, Supl. 1, 2002, p. 14-24.

SCHNETZLER, R. P. \& ARAGÃO, R. M. R. Importância, sentido e contribuições de pesquisas para o ensino de química. Química Nova na Escola. N.1, mai, 1995, p. 27-31.

SCHRECK, J.O.; LANG, C.M. Introduction to Chemistry on Stamps. Journal of Chemical Education, v.62, n.6, p.1041, 1985.

SENA, Silvio. de. 0 jogo como precursor de valores no contexto escolar. 2007. 242f. Dissertação (Mestrado em Educação) - Faculdade de Ciências e Tecnologia - UNESP - Campus de Presidente Prudente, 2007.

STAVROULAKIS, A. M. Meio-socks and other genetic yarns. The American Biology Teacher, vol. 67, nº 4, p. 233-238, april, 2005.

SEIPELT, R. L. Cookie-ases: Interactive models for teaching genotypephenotype relationships. The American Biology Teacher. Online publication. May, 2006, p. 48-53.

STENCEL, J.; BARKOFF, A. Protein Synthesis: Role Playing in the Classroom. The american Biology Teacher, vol. 55, $n^{\circ}$ 2, p.102-103, feb, 1993.

SMITH, M. K. \& KINDFIELD, A. C. Teaching cell division: basics and recommendations. The American Biology Teacher. N. 61, 1999, p.366-371.

SOARES, M.H.F.B. Jogos para o ensino de Química: Teoria, métodos e aplicações. Guarapari: Libris, 2008.

SOARES, M.H.F.B. e CAVALHEIRO, E.T.G. (2006). Ludo termoquímico: um jogo para ensinar conceitos em termoquímica. Química Nova na Escola, 24, $17-21$.

SOARES, M.H.F.B. O lúdico em Química: jogos e atividades aplicados ao ensino de Química. São Carlos (São Paulo), 2004, 175p. Tese de Doutorado. - departamento de Química, Instituto de Ciências Exatas e de TecnologiaUniversidade Federal de São Carlos. Orientador: Éder Tadeu Gomes Cavalheiro.

SOARES, M.H.F.B.; OKUMURA, F; CAVALHEIRO, E.T.G. Proposta de um jogo didático para ensinar o conceito de equilíbrio químico. Química Nova na Escola, n.18, p.13, 2003.

SOUZA, S.F. e ALVES, M.C. Texto apostilado apresentado no mini-curso A importância do lúdico no ensino de ciências - XIV ECODEQ - UFMT - Cuiabá: 2005. 
STENCEL, J. \& BARKOFF, A. Protein Synthesis: Role Playing in the Classroom. The american Biology Teacher. V. 55, n. 2, feb, 1993, p.102-103.

UTCHINSON, B.; WILLERTON, C. Slanging in Science. Journal of Chemical Education, v.62, n.6, p.1048, 1985.

VALENTIM, M. L. P. Métodos qualitativos de pesquisa em Ciência da Informação. São Paulo: Polis, 2005. 176p.

VALENZUELA, A. V. O jogo no ensino fundamental. In: MURCIA, J. A. M.Aprendizagem através do jogo. Porto Alegre: Artmed, 2005.

VEER, R. \& VALSINER J. Vygotsky, uma síntese. São Paulo: Unimarco Ed., 1996.

VYGOTSKY, L. S. A formação social da mente: O papel do brinquedo no desenvolvimento. 7a ed., São Paulo: Martins Fontes, 2007, p. 169.

VYGOTSKY, L. S. Pensamento e Linguagem, 3ed, São Paulo: Martins, 2005.

VYGOTSKY, L. S. Psicologia pedagógica. S. Paulo: Martins Fontes, 2001.

VYGOTSKY, L. S. A construção do Pensamento e da Linguagem. S. Paulo: Martins Fontes, 2000.

VYGOTSKY, L. S. O desenvolvimento psicológico na infância. S. Paulo: Martins Fontes. 1999.

WADDELL, T.G.; RYBOLT, T.R. The chemical adventure of Sherlock Holmes. Journal of Chemical Education, v.78, n.4, p.471, 2001; v.77, n.4, p.471, 2000; v.75, n.4, p.484, 1998; v.73, n.6, p.1157, 1996.

WATANABE, M; RECENA, M. C. P; Memória Orgânica - Um jogo didático útil no processo de ensino e aprendizagem, IV Encontro Nacional de Ensino de Química (XIV ENEQ), UFPR, Curitiba/PR 2008.

WATANABE, M. e RECENA, M.C.P.Jogo de Memória - A contribuição do lúdico no aprendizado de funções orgânicas. In: XIII Encontro Nacional de Ensino de Química, Campinas. Anais do XIII Encontro Nacional de Ensino de Química, Campinas,2006.

WINNICOTT, D. W. O brincar e a realidade. Rio de Janeiro: Imago, 1975, p. 203.

WYN, M. A. \& STEIGINK, S. J. Role-Playing Mitosis. The American Biology Teacher. V. 62, n. 5, may, 2000, p.378-381.

ZANON, D.A.V.; GUERREIRO, M.A.S. e OLIVEIRA, R.C. (2008). Jogo didático Ludo Químico para o ensino de nomenclatura dos compostos orgânicos:

projeto, produção, aplicação e avaliação. Ciências \& Cognição, 13 (1), 72-81. 